\title{
Angewandte
}

Supporting Information

\section{A Stable Crystalline Triarylphosphine Oxide Radical Anion}

Tobias A. Schaub, Eva M. Zolnhofer, Dominik P. Halter, Tatyana E. Shubina, Frank Hampel, Karsten Meyer, and Milan Kivala*

anie_201605963_sm_miscellaneous_information.pdf 


\section{Table of Contents}

1. Experimental details

2. Synthesis

3. Nuclear magnetic resonance spectra

4. X-ray crystallographic analysis

5. Thermogravimetric analysis

6. Photophysical properties

7. Cyclic voltammetry measurements

8. Electron paramagnetic resonance measurements

9. Computational details

10. References 


\section{Experimental details}

General. Starting materials were purchased reagent grade from Acros, Sigma-Aldrich, and Alfa Aesar, and used without further purification. Tetrahydrofuran (THF) and diethyl ether $\left(\mathrm{Et}_{2} \mathrm{O}\right)$ were dried over $\mathrm{KOH}$ and subsequently distilled over sodium metal. Complete dryness was indicated by the dark blue benzophenone ketyl radical anion. $\mathrm{CH}_{2} \mathrm{Cl}_{2}$ was dried over $\mathrm{CaCl}_{2}$ and subsequently distilled over $\mathrm{CaH}_{2}$. For usage in the glovebox THF and $n$-pentane were purified using a two column solid-state purification system (Glasscontour System, Joerg Meyer, Irvine, CA), transferred to the glovebox without exposure to air and stored over activated molecular sieves and/or sodium metal. Compound $\mathbf{2}$ was prepared according to a modified procedure from the literature. ${ }^{[1]}$ Reactions were carried out in flame-dried glassware and under an inert atmosphere of purified nitrogen using Schlenk techniques or an MBraun inert-gas glovebox containing an atmosphere of purified nitrogen. Thin-layer chromatography (TLC) was performed on the aluminium plates coated with $0.20 \mathrm{~mm}$ thickness of Silica Gel 60 F-254 (MachereyNagel). Column chromatography was performed on silica gel (230 - 400 mesh). ${ }^{1} \mathrm{H}$ NMR, ${ }^{13} \mathrm{C}$ NMR, and ${ }^{31} \mathrm{P}$ NMR spectra were recorded on a Bruker Avance 400 spectrometer $(400.1 \mathrm{MHz}$ for ${ }^{1} \mathrm{H}, 162.0 \mathrm{MHz}$ for ${ }^{31} \mathrm{P}$, and $100.6 \mathrm{MHz}$ for ${ }^{13} \mathrm{C}$ ) in $\mathrm{CD}_{2} \mathrm{Cl}_{2}$ at RT. Chemical shifts $(\delta)$ are reported in ppm and were referenced to the residual solvent signal as an internal reference $\left(\mathrm{CD}_{2} \mathrm{Cl}_{2}, 5.32 \mathrm{ppm}\right.$ for ${ }^{1} \mathrm{H}$ and 53.8 for $\left.{ }^{13} \mathrm{C}\right)$ or to external $85 \% \mathrm{H}_{3} \mathrm{PO}_{4}\left({ }^{31} \mathrm{P}\right)$. Coupling constants $(J)$ are given in $\mathrm{Hz}$ and the apparent resonance multiplicity is reported as s (singlet), $\mathrm{d}$ (doublet), $\mathrm{t}$ (triplet), q (quartet), quint (quintet) or $\mathrm{m}$ (multiplet). Mass spectra were obtained from a MicrOTOF II (Bruker, HR ESI and APPI) or a MaXis 4G (Bruker, ESI) mass spectrometer. The signal of the molecular ion $[\mathrm{M}]^{+}$is reported in $\mathrm{m} / \mathrm{z}$ units. Melting points were determined on a Büchi M-560 melting-point apparatus in open capillaries and are reported uncorrected. "Decomp" refers to decomposition. Thermogravimetric analysis (TGA) was recorded on a Pyris 1 TGA (Perkin Elmer) instrument. All thermal analyses were carried out under a flow of nitrogen with a heating rate of $10{ }^{\circ} \mathrm{C} / \mathrm{min}$. Thermal decomposition temperature were reported as the first significant weight loss $>5 \%$. Elemental analyses were measured by the Microanalytic Laboratory (Institute for Organic Chemistry, University of Erlangen-Nürnberg). Infrared spectra (IR) spectra were recorded on a 660-IR (Varian, ATR mode) spectrometer. Characteristic IR absorptions are reported in $\mathrm{cm}^{-1}$ and denoted as strong (s), medium (m), and weak (w). Electronic absorption spectra measured inside a glovebox were recorded with an Analytik Jena Specord S600 spectrophotometer. The samples were prepared under anaerobic conditions and the solutions 
were continuously stirred with a magnet bar, where appropriate. UV/vis absorption and fluorescence spectra measured under ambient conditions were recorded with a Cary 5000 UV/vis/NIR (Varian) spectrophotometer and a Horiba Jobin Yvon fluoromax-4 spectrofluorometer, respectively. All measurements were carried out in QS Quartz Suprasil cells (10 mm light path). The absorption maxima $\left(\lambda_{\max }\right)$ are reported in nanometers and the extinction coefficient $(\varepsilon)$ in $\mathrm{M}^{-1} \mathrm{~cm}^{-1}$. Relative fluorescence quantum yields were calculated using quinine bisulfate in aqueous $0.1 \mathrm{M} \mathrm{H}_{2} \mathrm{SO}_{4}(\Phi=0.54)$ as standard. ${ }^{[2]}$ Quantum yields were determined using equation (1):

$$
\phi_{\mathrm{x}}=\phi_{\mathrm{s}} \cdot \frac{l_{\mathrm{s}}}{l_{\mathrm{x}}} \cdot \frac{A_{\mathrm{s}}}{A_{\mathrm{x}}} \cdot \frac{n_{\mathrm{s}}^{2}}{n_{\mathrm{x}}^{2}}
$$

The $\mathrm{x}$ subscript refers to the unknown and s to the standard, $\Phi$ stands for the quantum yield, $I$ for the integrated emission spectra, $A$ stands for the absorbance at the excitation wavelength, $n$ stands for the refractive index of the solvent being used $\left(n_{\mathrm{x}}=1.424\left(\mathrm{CH}_{2} \mathrm{Cl}_{2}\right)\right.$ and $n_{\mathrm{s}}=1.334(0.1 \mathrm{M}$ $\left.\mathrm{H}_{2} \mathrm{SO}_{4}\right) .{ }^{[3]}$ The quotient $A_{\mathrm{S}} / A_{\mathrm{x}}=1$, because the intersection of the absorption spectrum of the sample and the standard was used as the excitation wavelength. The electrochemistry was investigated using a three-electrode setup with rotating disk glassy carbon working electrode, and platinum rods as counter- and reference electrode. The potentiostat was a $\mu$-Autolab Type-III. The electrochemical cell was placed inside an inert-gas glovebox under nitrogen atmosphere and the samples were measured in $0.1 \mathrm{M}$ electrolyte solutions of $n \mathrm{Bu}_{4} \mathrm{NPF}_{6}$ (purchased from Acros and used without further purification) in $\mathrm{CH}_{2} \mathrm{Cl}_{2}$ or THF. The reported half-wave potentials are referenced to the ferrocenium/ferrocene $\left(\mathrm{Fc}^{+} / \mathrm{Fc}\right)$ redox couple by adding ferrocene to the sample solution. Electron paramagnetic resonance (EPR) spectra were recorded on a JEOL continuous wave spectrometer JES-FA200 equipped with an X-band Gunn oscillator bridge, and a cylindrical mode cavity. A freshly prepared $0.4 \mathrm{mM}$ solution of $\mathbf{1}^{--}[\mathrm{K} \subset[2.2 .2] \text { cryptand }]^{+}$in $\mathrm{THF}$ was transferred to a quartz capillary, which was sealed in an air-tight J. Young-type quartz EPR tube. Background spectra were obtained on neat solvents under the same measurement conditions. If not stated otherwise, the spectra shown were measured with the following parameters: Room temperature $25{ }^{\circ} \mathrm{C}(\mathrm{RT})$, microwave frequency $8.956 \mathrm{GHz}$, modulation width $0.2 \mathrm{mT}$, microwave power $1.0 \mathrm{~mW}$, modulation frequency $100 \mathrm{kHz}$, and time constant $0.1 \mathrm{~s}$. Spectral simulation was performed using the program W95EPR written by F. Neese. ${ }^{[4]}$ X-Ray crystallographic data was measured on a Supernova CCD diffractometer (Agilent) at $173 \mathrm{~K}$. The structures were solved by direct methods using Olex $2^{[5]}$ and refined with SHELX. ${ }^{[6]}$ After full- 
matrix least-square refinement of the non-hydrogen atoms with anisotropic thermal parameters, the hydrogen atoms were placed in calculated positions using a riding model. CCDC-1420823, 1420824, 1420825 and 1420826 contain the supplementary crystallographic data for this paper. These data can be obtained free of charge from the Cambridge Crystallographic Data Centre (www.ccdc.cam.ac.uk/data_request/cif). 


\section{Synthesis}

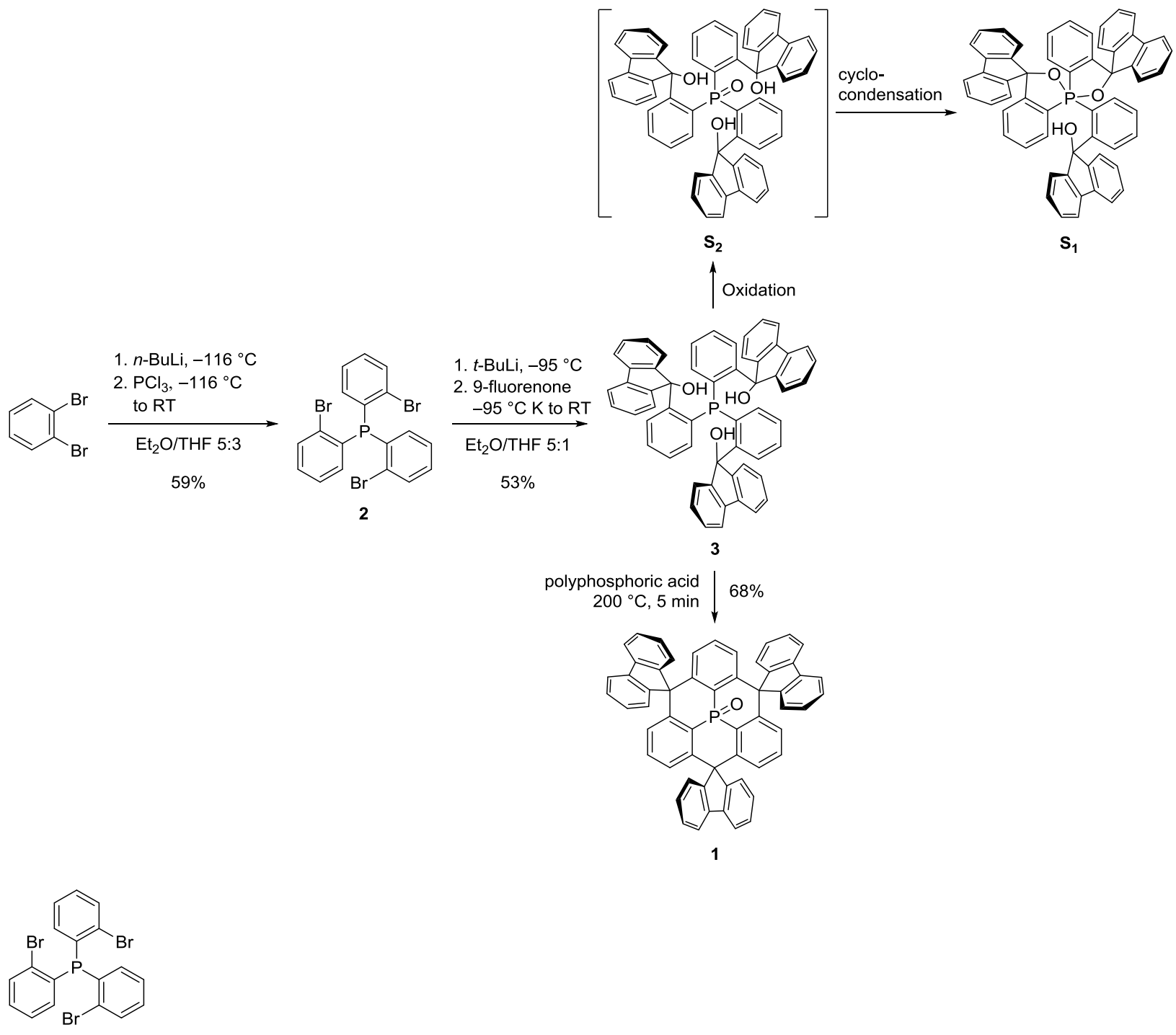

Compound 2. At $-116{ }^{\circ} \mathrm{C}\left(\mathrm{Et}_{2} \mathrm{O} /\right.$ liq. $\left.\mathrm{N}_{2}\right), n$-BuLi (1.60 $\mathrm{M}$ in hexanes, $\left.52.2 \mathrm{~mL}, 83.6 \mathrm{mmol}\right)$ was added dropwise over $30 \mathrm{~min}$ to a solution of 1,2-dibromobenzene (19.7 g, $83.6 \mathrm{mmol}$ ) in $\mathrm{Et}_{2} \mathrm{O}$ $(134 \mathrm{~mL})$ and THF $(80 \mathrm{~mL})$. The mixture was stirred for additional $2 \mathrm{~h}$ at $-116{ }^{\circ} \mathrm{C}$. To this mixture kept at $-116^{\circ} \mathrm{C}$, a solution of $\mathrm{PCl}_{3}(3.64 \mathrm{~g}, 26.5 \mathrm{mmol})$ in $\mathrm{Et}_{2} \mathrm{O}(14 \mathrm{~mL})$ and $\mathrm{THF}(8 \mathrm{~mL})$ was added dropwise over $10 \mathrm{~min}$ via a dropping funnel. The reaction temperature was maintained for additional $2 \mathrm{~h}$ before the mixture was allowed to warm to RT overnight. Aqueous $\mathrm{NH}_{4} \mathrm{Cl}$ (sat., $50 \mathrm{~mL}$ ) was added and the volatiles were removed under reduced pressure. The aqueous phase was extracted with $\mathrm{CH}_{2} \mathrm{Cl}_{2}(3 \times 60 \mathrm{~mL})$, and the combined organic phases were washed with water $(1 \times 40 \mathrm{~mL})$ and dried $\left(\mathrm{MgSO}_{4}\right)$. After filtration, $\mathrm{MeOH}(80 \mathrm{~mL})$ was added and the 
solution was concentrated under reduced pressure until precipitation occurred. Filtration afforded the crude product which was purified by recrystallization from hot $\mathrm{MeOH}(230 \mathrm{~mL})$ to give title compound 2 (7.82 g, 59\%) as a white powder.

$R_{f}=0.57\left(\mathrm{SiO}_{2}, \mathrm{CH}_{2} \mathrm{Cl}_{2} /\right.$ hexanes 1:3); $\mathrm{Mp} 104.8-106.4{ }^{\circ} \mathrm{C} ;{ }^{1} \mathrm{H} \mathrm{NMR}\left(\mathrm{CD}_{2} \mathrm{Cl}_{2}, 400 \mathrm{MHz}\right): \delta$ $7.72-7.61(\mathrm{~m}, 3 \mathrm{H}), 7.28$ (quintd, $J=7.4,1.7 \mathrm{~Hz}, 6 \mathrm{H}), 6.78(\mathrm{dt}, J=7.5,2.1 \mathrm{~Hz}, 3 \mathrm{H}) \mathrm{ppm} ;{ }^{13} \mathrm{C}$ NMR $\left(\mathrm{CD}_{2} \mathrm{Cl}_{2}, 100 \mathrm{MHz}\right): \delta 137.1(\mathrm{~d}, J(\mathrm{C}, \mathrm{P})=11.9 \mathrm{~Hz}), 135.2(\mathrm{~s}), 133.6(\mathrm{~d}, J(\mathrm{C}, \mathrm{P})=2.6 \mathrm{~Hz})$, $131.3(\mathrm{~s}), 130.6(\mathrm{~d}, J(\mathrm{C}, \mathrm{P})=34.2 \mathrm{~Hz}), 128.3(\mathrm{~s}) \mathrm{ppm} ;{ }^{31} \mathrm{P} \mathrm{NMR}\left(\mathrm{CD}_{2} \mathrm{Cl}_{2}, 162 \mathrm{MHz}\right): \delta-3.2 \mathrm{ppm}$; IR (ATR): $\tilde{v} 2924$ (w, C-H), 1447 (m, P-Aryl), 1417 (m) 1018 (s, Aryl-Br), 752 (s) cm ${ }^{-1}$; HRMS (APPI, THF/acetonitrile, positive mode): $m / z$ calcd for $\mathrm{C}_{18} \mathrm{H}_{12} \mathrm{Br}_{3} \mathrm{P}: 495.82213$ [M] ${ }^{+}$, found 495.82225; Spectral data were consistent with that reported in the literature. ${ }^{[1]}$

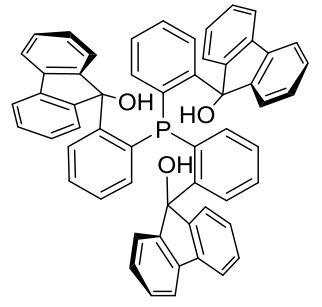

3

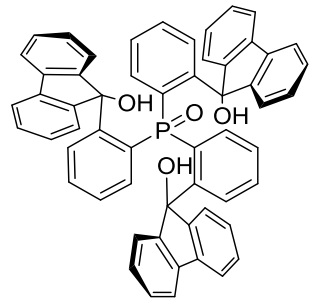

$\mathrm{s}_{2}$

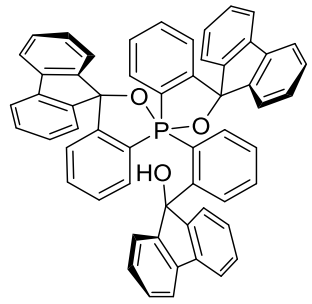

$\mathrm{s}_{1}$

Compound 3, S2, and S1. At $-95^{\circ} \mathrm{C}$ (acetone / liq. $\mathrm{N}_{2}$ ), $t$-BuLi (1.60 $\mathrm{M}$ in $n$-pentane), $18.8 \mathrm{~mL}$, $30.0 \mathrm{mmol}$ ) was added dropwise over $15 \mathrm{~min}$ to a solution of tris(2-bromophenyl)phosphine (2) (4.99 $\mathrm{g}, 10.0 \mathrm{mmol})$ in $\mathrm{Et}_{2} \mathrm{O}(175 \mathrm{~mL})$ and THF $(35 \mathrm{~mL})$. After the addition was completed, the clear yellow mixture was stirred for additional $30 \mathrm{~min}$ at $-95{ }^{\circ} \mathrm{C}$. Then, a solution of 9-fluorenone $(5.95 \mathrm{~g}, 33.0 \mathrm{mmol})$ in $\mathrm{Et}_{2} \mathrm{O}(40 \mathrm{~mL})$ and $\mathrm{THF}(8 \mathrm{~mL})$ was added dropwise over 30 min via dropping funnel at $-95^{\circ} \mathrm{C}$. The reaction temperature was maintained at $-95^{\circ} \mathrm{C}$ for additional $5 \mathrm{~h}$, until the mixture was allowed to warm to RT overnight. To the resulting dark green reaction mixture, aqueous $\mathrm{NH}_{4} \mathrm{Cl}$ (sat., $30 \mathrm{~mL}$ ) was added and the volatiles were removed under reduced pressure. The aqueous phase was extracted with $\mathrm{CH}_{2} \mathrm{Cl}_{2}(3 \times 50 \mathrm{~mL})$, the combined organic phases were washed with water $(1 \times 40 \mathrm{~mL})$ and dried $\left(\mathrm{MgSO}_{4}\right)$. After filtration, $\mathrm{MeOH}(120$ $\mathrm{mL}$ ) was added and the solution was concentrated under reduced pressure until precipitation occurred. Filtration furnished a mixture of target compound 3, S1 and S2 (4.24 g, 53\%). Column chromatography $\left(\mathrm{SiO}_{2}, \mathrm{CH}_{2} \mathrm{Cl}_{2} /\right.$ hexanes 4:1) afforded compound 3 (1.56 g, 19\%) and $\mathbf{S 1}$ (2.43, $30 \%$ ) as white solids. Phosphine $\mathbf{3}$ was prone to oxidation yielding the P(V)-species S1 (see Figure S20) after spontaneous intramolecular cyclocondensation during column chromatography 
of the initially formed phosphine oxide $\mathbf{S 2}$ as reported previously by Hellwinkel and Krapp. ${ }^{[7]}$ Hence, $\mathbf{S 2}$ could not be isolated.

3: $R_{f} 0.65\left(\mathrm{SiO}_{2}, \mathrm{CH}_{2} \mathrm{Cl}_{2} /\right.$ hexanes 4:1); $\mathrm{Mp} 234.5-235.8{ }^{\circ} \mathrm{C} ;{ }^{1} \mathrm{H}$ NMR $\left(\mathrm{CD}_{2} \mathrm{Cl}_{2} / \mathrm{CD}_{3} \mathrm{OD} 10: 1,400\right.$ MHz): $\delta 7.69(\mathrm{~d}, J=7.5 \mathrm{~Hz}, 3 \mathrm{H}), 7.61(\mathrm{~d}, J=7.5 \mathrm{~Hz}, 3 \mathrm{H}), 7.43$ (t, $J=7.9 \mathrm{~Hz}, 3 \mathrm{H}), 7.36(\mathrm{ddd}, J$ $=8.4,7.4,0.9 \mathrm{~Hz}, 3 \mathrm{H}), 7.33-7.23(\mathrm{~m}, 6 \mathrm{H}), 7.17(\mathrm{td}, J=7.5,0.9 \mathrm{~Hz}, 3 \mathrm{H}), 7.06(\mathrm{~d}, J=6.3 \mathrm{~Hz}$, $3 \mathrm{H}), 6.90(\mathrm{td}, J=7.4,0.8 \mathrm{~Hz}, 3 \mathrm{H}), 6.71-6.56(\mathrm{~m}, 6 \mathrm{H}), 6.32(\mathrm{~d}, J=7.6 \mathrm{~Hz}, 3 \mathrm{H}), 3.00(\mathrm{br}, \mathrm{s}, 3 \mathrm{H})$ ppm; ${ }^{13} \mathrm{C} \mathrm{NMR}\left(\mathrm{CD}_{2} \mathrm{Cl}_{2} / \mathrm{CD}_{3} \mathrm{OD}\right.$ 10:1, $\left.100 \mathrm{MHz}\right): \delta 150.6$ (s), 150.5 (s), 144.9 (d, J(C,P) = 10.7 Hz), 141.6 (s), 140.4 (s), 140.3 (s), 130.7 (s), 130.5 (s), 130.1 (s), 129.04 (s), 128.96 (s), 128.3 (s), 128.2 (s), 126.9 (s), $126.8(\mathrm{~s}), 125.8$ (d, J(C,P) = $10.9 \mathrm{~Hz}), 125.1(\mathrm{~s}), 120.0$ (d, J(C,P) = 32.4 $\mathrm{Hz}), 87.4$ (s) ppm; ${ }^{31} \mathrm{P}$ NMR $\left(\mathrm{CD}_{2} \mathrm{Cl}_{2} / \mathrm{CD}_{3} \mathrm{OD}\right.$ 10:1, $\left.162 \mathrm{MHz}\right): \delta-21.0 \mathrm{ppm}$; UV/vis $\left(\mathrm{CH}_{2} \mathrm{Cl}_{2}\right)$ : $\lambda_{\max }(\varepsilon) 311$ (6990), 277 (28400) nm; IR (ATR): $\tilde{v} 3058$ (w, C-H), 1444 (m, P-Aryl), 1179 (m), 1102 (m, C-O), 1014 (s, P-OAlkyl), 736 (s) cm cm $^{-1}$ HRMS (ESI, toluene/acetonitrile, positive mode): $m / z$ calcd $\quad \mathrm{C}_{57} \mathrm{H}_{38} \mathrm{O}_{3} \mathrm{P}: \quad 801.25531 \quad\left[\left(\mathrm{M}+\mathrm{H}-\mathrm{H}_{2} \mathrm{O}\right)\right]^{+}$, found 801.25498 (Only cyclocondensation product $\mathbf{S 1}$ formed upon ionization of $\mathbf{3}$, could be detected in MS).

S1: $R_{f} 0.85\left(\mathrm{SiO}_{2}, \mathrm{CH}_{2} \mathrm{Cl}_{2} /\right.$ hexanes 4:1); $\mathrm{Mp} 346.4{ }^{\circ} \mathrm{C}$ (decomp); ${ }^{1} \mathrm{H}$ NMR $\left(\mathrm{CD}_{2} \mathrm{Cl}_{2}, 400 \mathrm{MHz}\right): \delta$ $8.65(\mathrm{t}, J=8.6 \mathrm{~Hz}, 1 \mathrm{H}), 8.42-8.31(\mathrm{~m}, 1 \mathrm{H}), 8.00(\mathrm{ddd}, J=18.7,8.1,1.1 \mathrm{~Hz}, 1 \mathrm{H}), 7.86(\mathrm{~d}, J=7.6$ $\mathrm{Hz}, 1 \mathrm{H}), 7.83(\mathrm{dd}, J=7.5,3.4 \mathrm{~Hz}, 2 \mathrm{H}), 7.77(\mathrm{~d}, J=7.5 \mathrm{~Hz}, 1 \mathrm{H}), 7.60(\mathrm{~d}, J=7.5 \mathrm{~Hz}, 1 \mathrm{H}), 7.54$ $(\mathrm{d}, J=7.5 \mathrm{~Hz}, 1 \mathrm{H}), 7.51-7.34(\mathrm{~m}, 5 \mathrm{H}), 7.33-7.19(\mathrm{~m}, 7 \mathrm{H}), 7.19-6.99(\mathrm{~m}, 7 \mathrm{H}), 6.95(\mathrm{t}, J=7.6$ $\mathrm{Hz}, 1 \mathrm{H}), 6.68(\mathrm{ddd}, J=17.9,11.3,5.3 \mathrm{~Hz}, 3 \mathrm{H}), 6.58(\mathrm{td}, J=7.5,0.9 \mathrm{~Hz}, 1 \mathrm{H}), 6.44(\mathrm{~d}, J=7.6 \mathrm{~Hz}$, $1 \mathrm{H}), 6.38(\mathrm{td}, J=7.9,1.2 \mathrm{~Hz}, 1 \mathrm{H}), 5.54(\mathrm{~d}, J=7.6 \mathrm{~Hz}, 1 \mathrm{H}), 5.39(\mathrm{~s}, 1 \mathrm{H}) \mathrm{ppm} ;{ }^{13} \mathrm{C}$ NMR $\left(\mathrm{CD}_{2} \mathrm{Cl}_{2}, 100 \mathrm{MHz}\right): \delta 153.1$ (s), 153.0 (s), 150.71 (s), 150.68 (d, J(C,P) = $\left.12.2 \mathrm{~Hz}\right), 150.4(\mathrm{~d}$, $J(\mathrm{C}, \mathrm{P})=13.1 \mathrm{~Hz}), 150.1(\mathrm{~d}, J(\mathrm{C}, \mathrm{P})=16.1 \mathrm{~Hz}), 149.4(\mathrm{~s}), 145.7(\mathrm{~s}), 143.8(\mathrm{~s}), 141.9(\mathrm{~s}), 141.8(\mathrm{~s})$, 141.1 (s), 140.9 (s), 140.5 (s), 140.2 (s), 140.0 (s), 139.8 (s), 137.1 (s), 137.0 (s), 133.9 (s), 133.8 $(\mathrm{s}), 133.7(\mathrm{~s}), 133.2(\mathrm{~d}, J(\mathrm{C}, \mathrm{P})=2.8 \mathrm{~Hz}), 132.7(\mathrm{~d}, J(\mathrm{C}, \mathrm{P})=3.4 \mathrm{~Hz}), 132.1(\mathrm{~d}, J(\mathrm{C}, \mathrm{P})=2.8 \mathrm{~Hz})$, 130.3 (s), 130.2 (s), 129.6 (s), 129.4 (s), 129.3 (s), 129.2 (s), 129.0 (s), 128.6 (s), 128.5 (s), 128.44 (s), 128.41 (s), 128.3 (s), 128.2 (s), 128.0 (s), 127.9 (s), 127.8 (s), 126.7 (s), 126.0 (d, $J(\mathrm{C}, \mathrm{P})=16.6 \mathrm{~Hz}), 125.9$ (s), 125.7 (s), 125.5 (s), 125.2 (s), 124.2 (d, J(C,P) = 15.5, Hz), 123.6 (d, $J(\mathrm{C}, \mathrm{P})=17.1 \mathrm{~Hz}), 120.5(\mathrm{~s}), 120.3(\mathrm{~s}), 120.2$ (s), 120.1 (s), $119.8(\mathrm{~s}), 90.6$ (d, J(C,P) = 3.2 Hz), $89.8(\mathrm{~d}, J(\mathrm{C}, \mathrm{P})=2.5 \mathrm{~Hz}), 86.7(\mathrm{~d}, J(\mathrm{C}, \mathrm{P})=3.2 \mathrm{~Hz}) \mathrm{ppm} ;{ }^{31} \mathrm{P} \mathrm{NMR}\left(\mathrm{CD}_{2} \mathrm{Cl}_{2}, 162 \mathrm{MHz}\right): \delta-27.0$ ppm; UV/vis $\left(\mathrm{CH}_{2} \mathrm{Cl}_{2}\right): \lambda_{\max }(\varepsilon) 3101$ (8431), 276 (32800) nm; IR (ATR): $\tilde{v} 3056$ (w, C-H), 1447 (m, P-Aryl), 1176 (m), 1102 (m, C-O), 1018 (s, P-OAlkyl), 734 (s) cm ${ }^{-1}$; HRMS (ESI, 
toluene/acetonitrile, positive mode): $m / z$ calcd $\mathrm{C}_{57} \mathrm{H}_{38} \mathrm{O}_{3} \mathrm{P}: 801.25531[(\mathrm{M}+\mathrm{H})]{ }^{+}$, found 801.25460 .

S2: $R_{f} 0.47\left(\mathrm{SiO}_{2}, \mathrm{CH}_{2} \mathrm{Cl}_{2} /\right.$ hexanes $\left.4: 1\right) ;{ }^{31} \mathrm{P} \mathrm{NMR}\left(\mathrm{CD}_{2} \mathrm{Cl}_{2}, 162 \mathrm{MHz}\right): \delta 70.2 \mathrm{ppm}$.

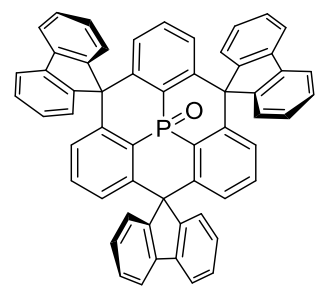

Compound 1. Compound 3 (600 $\mathrm{mg}, 0.75 \mathrm{mmol})$ was added in portions to vigorously stirred polyphosphoric acid $(115 \%, 36 \mathrm{~mL})$ kept at $200{ }^{\circ} \mathrm{C}$. The initially deep red solution turned grey within $5 \mathrm{~min}$. After this time the reaction mixture was allowed to cool to RT and was poured into ice water $(170 \mathrm{~mL})$. The resulting grey suspension was extracted with $\mathrm{CH}_{2} \mathrm{Cl}_{2}(4 \times 100 \mathrm{~mL})$ and the combined organic phases were washed with water $(1 \times 200 \mathrm{~mL})$ and dried $\left(\mathrm{MgSO}_{4}\right)$. Filtration and removal of the solvent under reduced pressure yielded the crude product, which was purified by column chromatography $\left(\mathrm{SiO}_{2}, \mathrm{CH}_{2} \mathrm{Cl}_{2}\right.$ ) to afford target compound 1 (387 $\mathrm{mg}$, $68 \%)$ as a microcrystalline colourless solid. $R_{f} 0.60\left(\mathrm{SiO}_{2}, \mathrm{CH}_{2} \mathrm{Cl}_{2}\right) ; \mathrm{Mp}>400{ }^{\circ} \mathrm{C}$; TGA: $T_{d} \approx 477$ ${ }^{\circ} \mathrm{C} ;{ }^{1} \mathrm{H}$ NMR $\left(\mathrm{CD}_{2} \mathrm{Cl}_{2}, 400 \mathrm{MHz}\right): \delta 8.78(\mathrm{~d}, J(\mathrm{H}, \mathrm{H})=7.2 \mathrm{~Hz}, 3 \mathrm{H}), 7.95(\mathrm{~d}, J(\mathrm{H}, \mathrm{H})=7.6 \mathrm{~Hz}$, $3 \mathrm{H}), 7.85(\mathrm{dd}, J(\mathrm{H}, \mathrm{H})=7.4,0.7 \mathrm{~Hz}, 3 \mathrm{H}), 7.53(\mathrm{td}, J(\mathrm{H}, \mathrm{H})=7.6,1.0 \mathrm{~Hz}, 3 \mathrm{H}), 7.37(\mathrm{td}, J(\mathrm{H}, \mathrm{H})=$ 7.4, $1.3 \mathrm{~Hz}, 3 \mathrm{H}), 7.31(\mathrm{t}, J(\mathrm{H}, \mathrm{H})=7.5 \mathrm{~Hz}, 6 \mathrm{H}), 6.97(\mathrm{~d}, J(\mathrm{H}, \mathrm{H})=7.7 \mathrm{~Hz}, 3 \mathrm{H}), 6.92(\mathrm{t}, J(\mathrm{H}, \mathrm{H})=$ $8.0 \mathrm{~Hz}, 3 \mathrm{H}), 6.52(\mathrm{dd}, J(\mathrm{H}, \mathrm{H})=8.0 \mathrm{~Hz}, J(\mathrm{H}, \mathrm{P})=4.1 \mathrm{~Hz}, 6 \mathrm{H}) \mathrm{ppm} ;{ }^{13} \mathrm{C} \mathrm{NMR}\left(\mathrm{CD}_{2} \mathrm{Cl}_{2}, 100\right.$ $\mathrm{MHz}): \delta 153.8(\mathrm{~s}), 152.6(\mathrm{~s}), 146.6(\mathrm{~d}, J(\mathrm{C}, \mathrm{P})=4.4 \mathrm{~Hz}), 143.1(\mathrm{~s}), 139.4(\mathrm{~s}), 132.0$ (s), $129.0(\mathrm{~s})$, 128.9 (s), 128.9 (s), 128.1 (s), 127.6 (d, J(C,P) = 8.2 Hz), $127.3(\mathrm{~s}), 126.8(\mathrm{~s}), 126.4(\mathrm{~d}, J(\mathrm{C}, \mathrm{P})=$ $103.1 \mathrm{~Hz}), 120.9(\mathrm{~s}), 120.3(\mathrm{~s}), 62.9(\mathrm{~d}, J(\mathrm{C}, \mathrm{P})=10.3 \mathrm{~Hz}) \mathrm{ppm} ;{ }^{31} \mathrm{P} \mathrm{NMR}\left(\mathrm{CD}_{2} \mathrm{Cl}_{2}, 162 \mathrm{MHz}\right): \delta$ -21.0 ppm; UV/vis $\left(\mathrm{CH}_{2} \mathrm{Cl}_{2}\right): \lambda_{\max }$ (ع) 310 (21700), 298 (18600) nm; IR (ATR): $\tilde{v} 3042$ (w, CH), $1573(\mathrm{~m}, \mathrm{C}=\mathrm{C}), 1446(\mathrm{~m}, \mathrm{C}=\mathrm{C}), 1199$ (m, P-O), $741(\mathrm{~s}) \mathrm{cm}^{-1}$; HRMS (APPI, toluene/acetonitrile positive mode): $\mathrm{m} / \mathrm{z}$ calcd for $\mathrm{C}_{57} \mathrm{H}_{33} \mathrm{OP}: 764.22635[\mathrm{M}]^{+}$, found 764.22522 ; Elemental analysis calcd (\%) for $\mathrm{C}_{57} \mathrm{H}_{33} \mathrm{OP} \cdot 1 / 2 \mathrm{H}_{2} \mathrm{O}$ : C 88.47, $\mathrm{H} 4.43$, found $\mathrm{C} 88.63 \mathrm{H} 4.41$. 


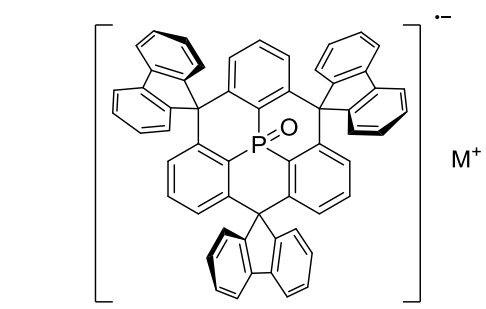

$\mathrm{M}^{+}=[\mathrm{K} \subset[2.2 .2] \text { cryptand }]^{+}$or $[\mathrm{K} \subset 18-\text { crown-6 }]^{+}$

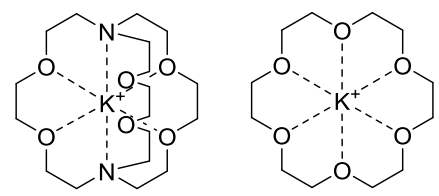

Radical anion $\mathbf{1}^{-}$. To a solution of phosphine oxide 1 (15.0 mg, $\left.19.6 \mu \mathrm{mol}\right)$ and 18-crown-6 $(5.50 \mathrm{mg}, 20.8 \mu \mathrm{mol})$ or [2.2.2]cryptand $(7.83 \mathrm{mg}, 20.8 \mu \mathrm{mol})$ in THF $(8 \mathrm{~mL})$ was added potassium metal (ca. $4.0 \mathrm{mg}$, exc.) at RT. The reaction mixture was stirred for $4 \mathrm{~h}$, while the colour turned to deep red. Residual potassium metal was removed by filtration through a plug of Celite to obtain a solution of $\mathbf{1}^{--}[\mathrm{K} \subset 18-\text { crown-6 }]^{+}$or $\mathbf{1}^{--}[\mathrm{K} \subset[2.2 .2] \text { cryptand }]^{+}$. Addition of $n$ pentane $(12 \mathrm{~mL})$ led to precipitate formation, which was filtered off, washed with $n$-pentane (10 $\mathrm{mL}$ ), and dried under vacuum to afford air-sensitive deep red solids $\mathbf{1}^{-}[\mathrm{K} \subset 18 \text {-crown-6 }]^{+}(15.6$ $\mathrm{mg}, 57 \%)$ or $\mathbf{1}^{--}[\mathrm{K} \subset[2.2 .2] \text { cryptand }]^{+}(6.9 \mathrm{mg}, 30 \%)$. Recrystallization from THF with slow diffusion of $n$-pentane at $-35{ }^{\circ} \mathrm{C}$ within 2 weeks under nitrogen atmosphere gave $\mathbf{1}^{\circ-}[\mathrm{K} \subset 18$ crown-6] $]^{+}$as deep red crystals suitable for X-ray crystallography. 


\section{Nuclear magnetic resonance spectra}

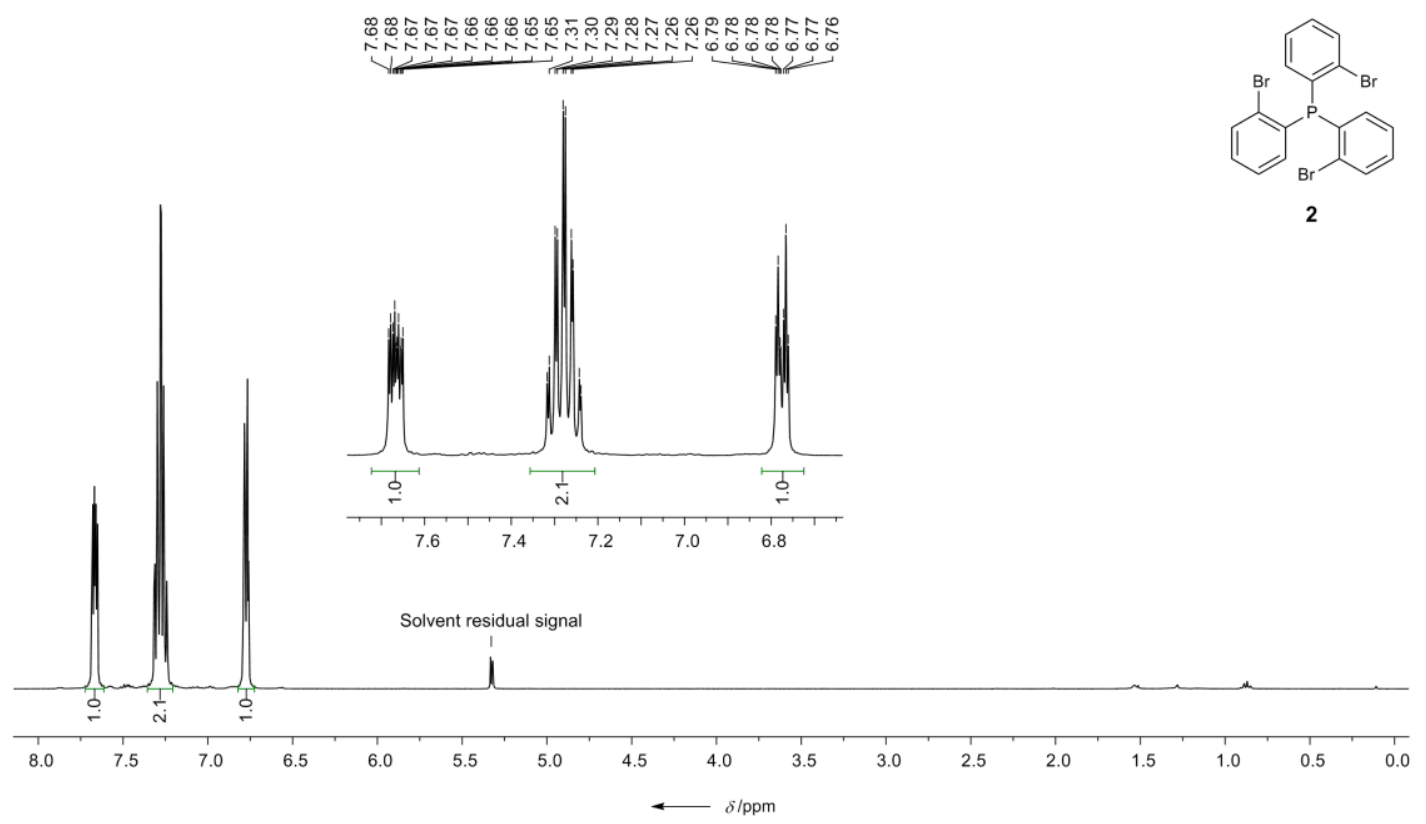

Figure S1. ${ }^{1} \mathrm{H}$ NMR spectrum $(400.1 \mathrm{MHz})$ of 2 in $\mathrm{CD}_{2} \mathrm{Cl}_{2}$ at RT.

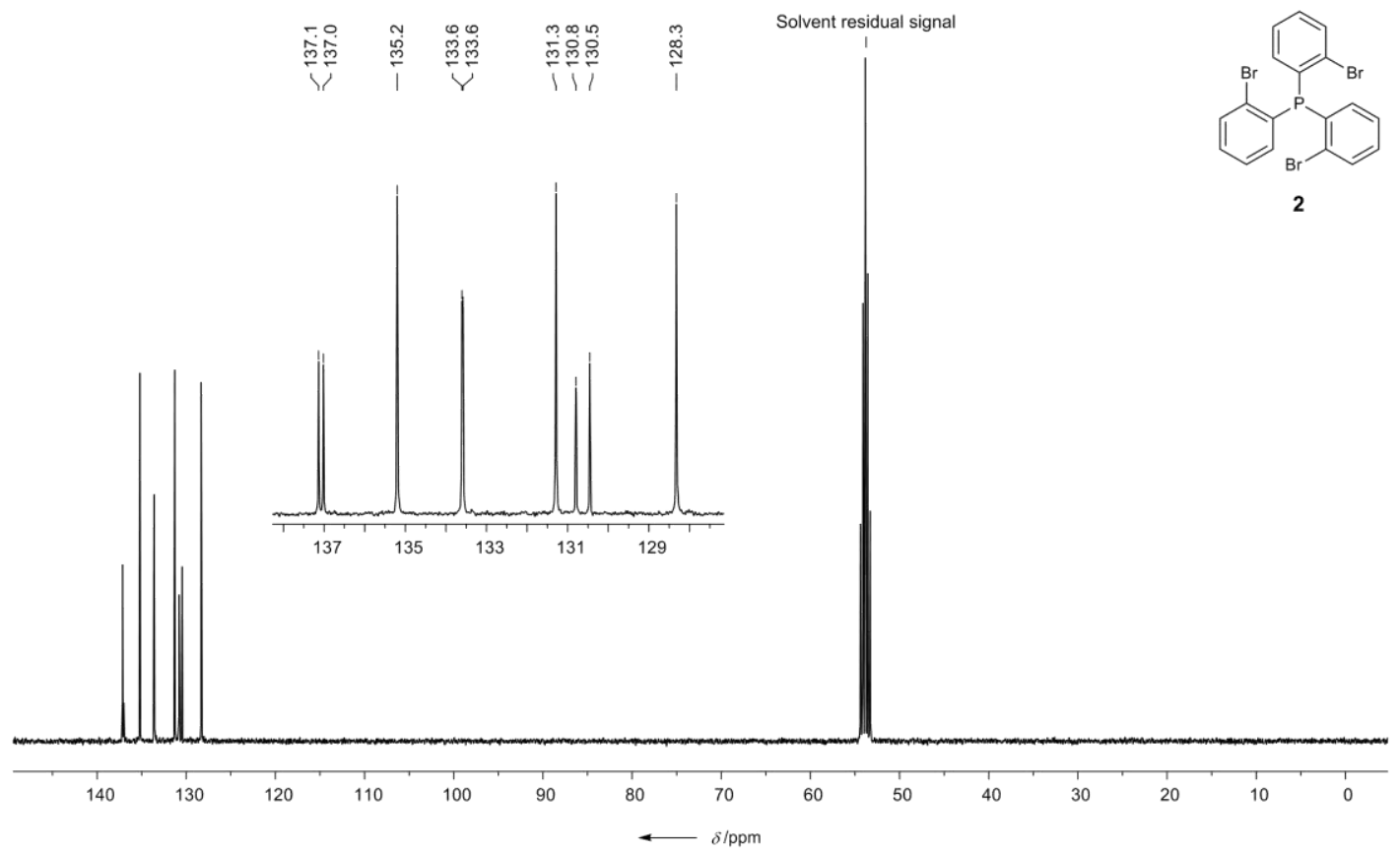

Figure S2. ${ }^{13} \mathrm{C}$ NMR spectrum $(100.6 \mathrm{MHz})$ of 2 in $\mathrm{CD}_{2} \mathrm{Cl}_{2}$ at RT. 


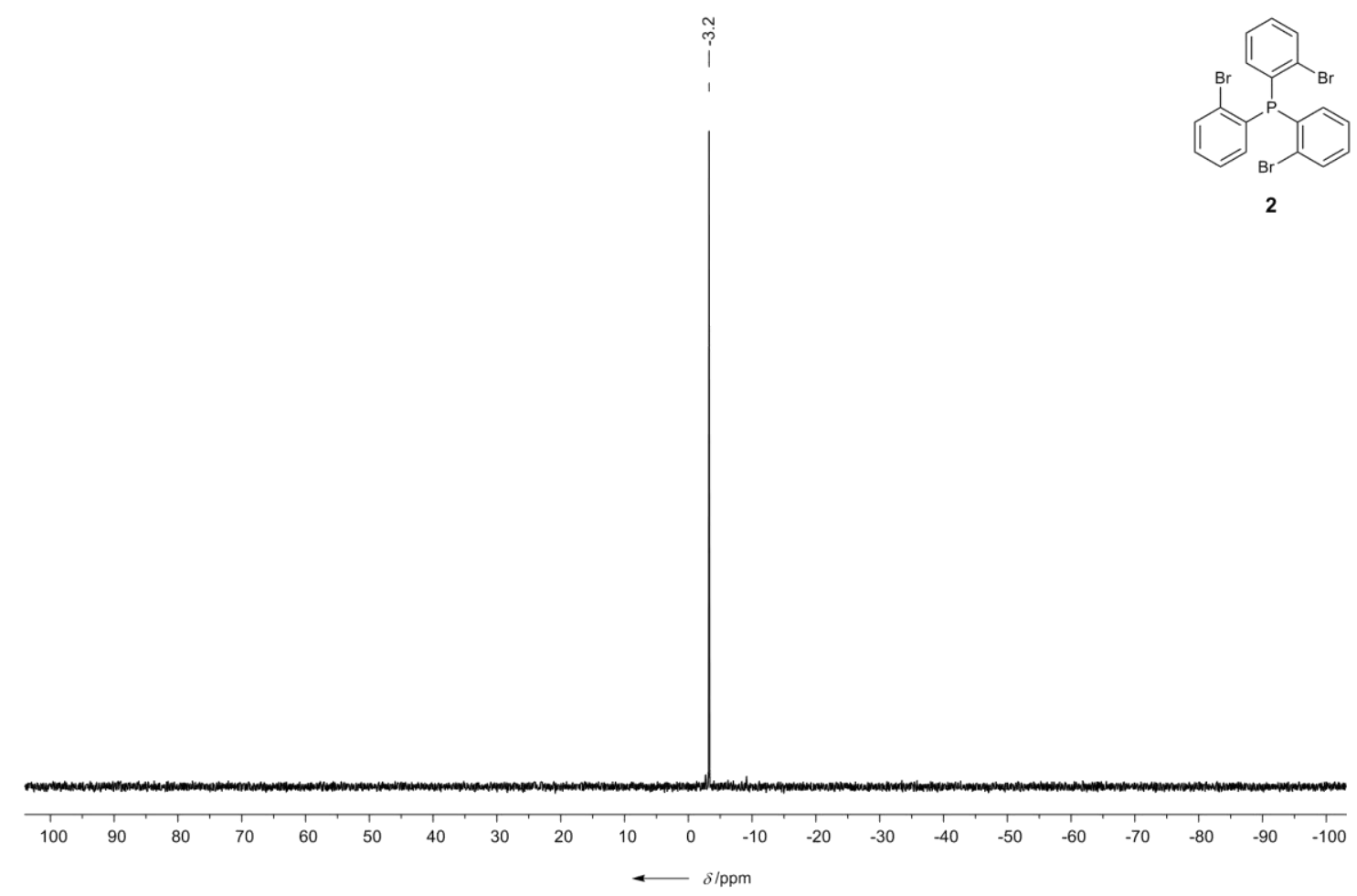

Figure S3. ${ }^{31} \mathrm{P}$ NMR spectrum $(162.0 \mathrm{MHz})$ of 2 in $\mathrm{CD}_{2} \mathrm{Cl}_{2}$ at RT.

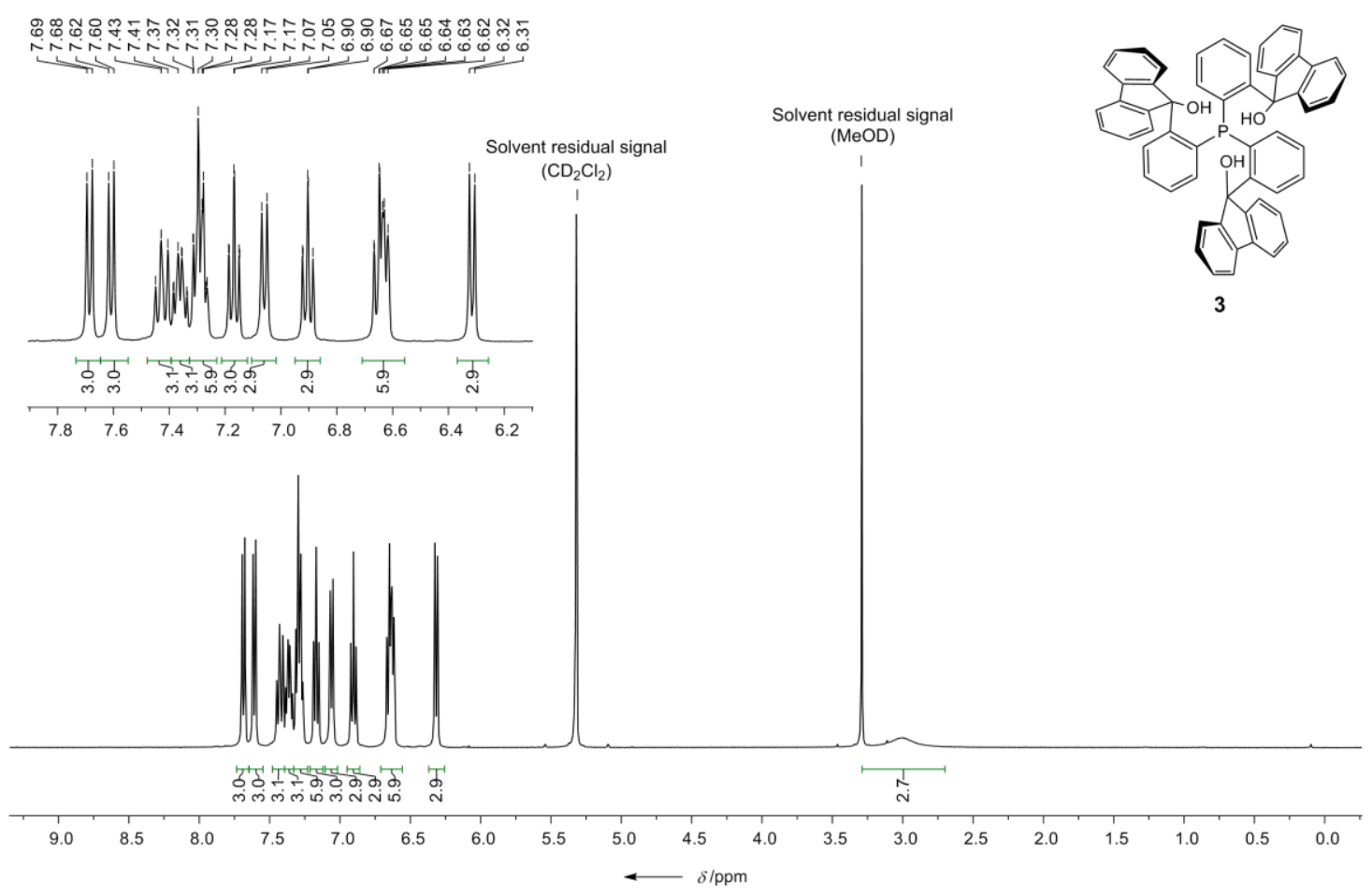

Figure S4. ${ }^{1} \mathrm{H}$ NMR spectrum $(400.1 \mathrm{MHz})$ of 3 in $\mathrm{CD}_{2} \mathrm{Cl}_{2} / \mathrm{CD}_{3} \mathrm{OD}$ 10:1 at RT. 


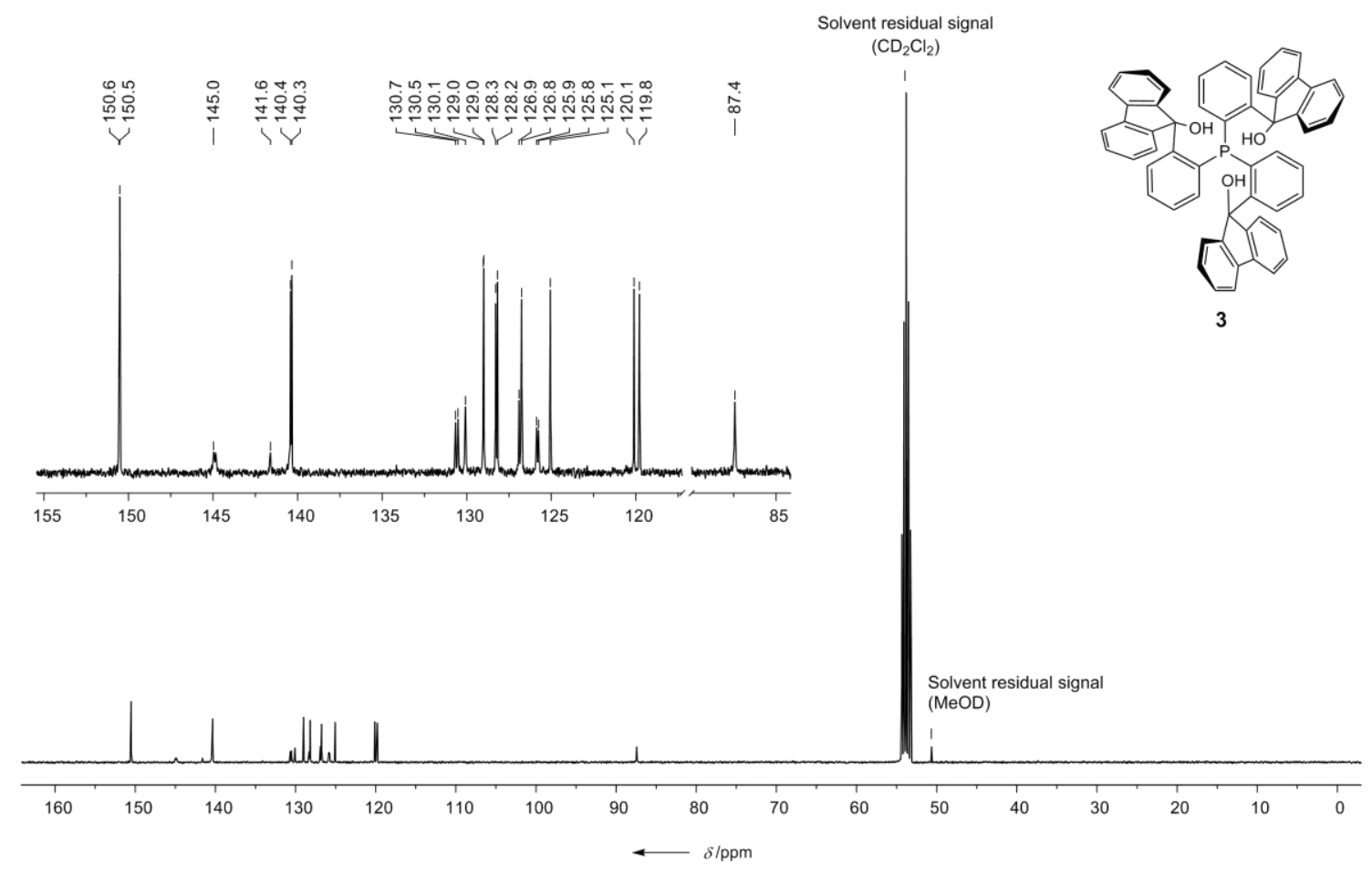

Figure S5. ${ }^{13} \mathrm{C}$ NMR spectrum (100.6 MHz) of 3 in $\mathrm{CD}_{2} \mathrm{Cl}_{2} / \mathrm{CD}_{3} \mathrm{OD} 10: 1$ at RT.

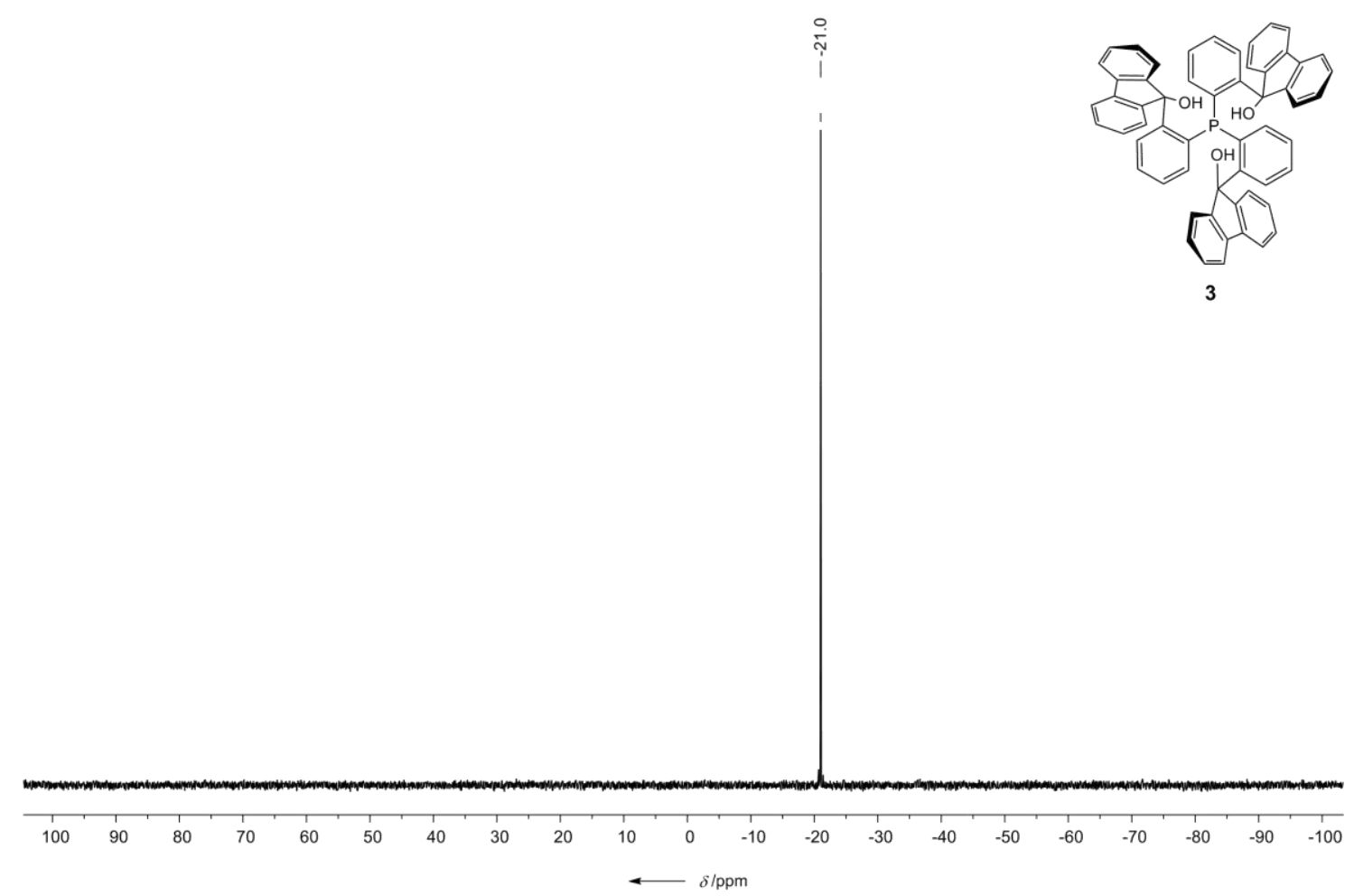

Figure S6. ${ }^{31} \mathrm{P}$ NMR spectrum $(162.0 \mathrm{MHz})$ of 3 in $\mathrm{CD}_{2} \mathrm{Cl}_{2} / \mathrm{CD}_{3} \mathrm{OD}$ 10:1 at RT. 


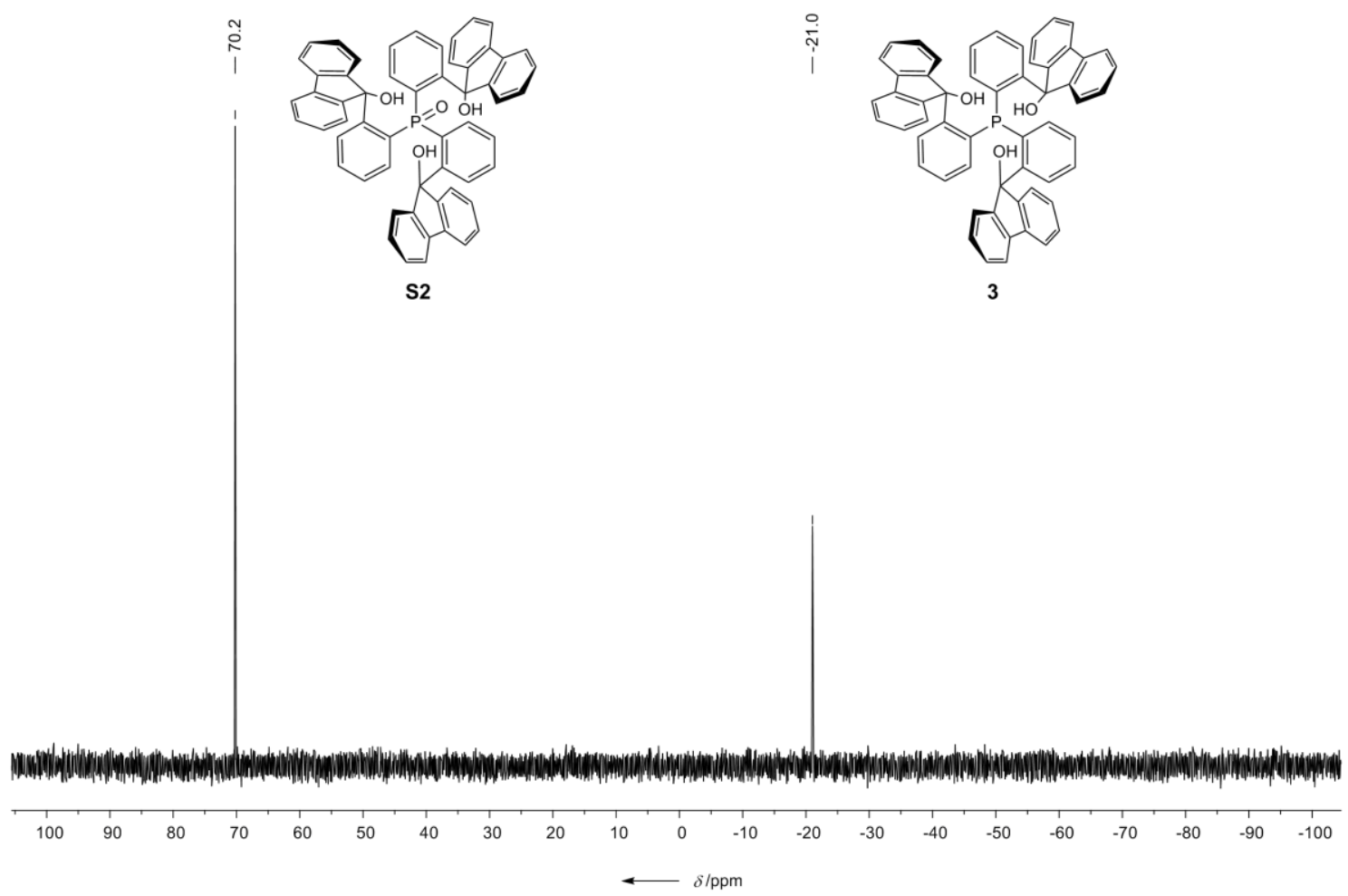

Figure S7. ${ }^{31} \mathrm{P}$ NMR spectrum $(162.0 \mathrm{MHz})$ of a mixture of $\mathbf{S 2}$ and $\mathbf{3}$ in $\mathrm{CD}_{2} \mathrm{Cl}_{2}$ at RT.

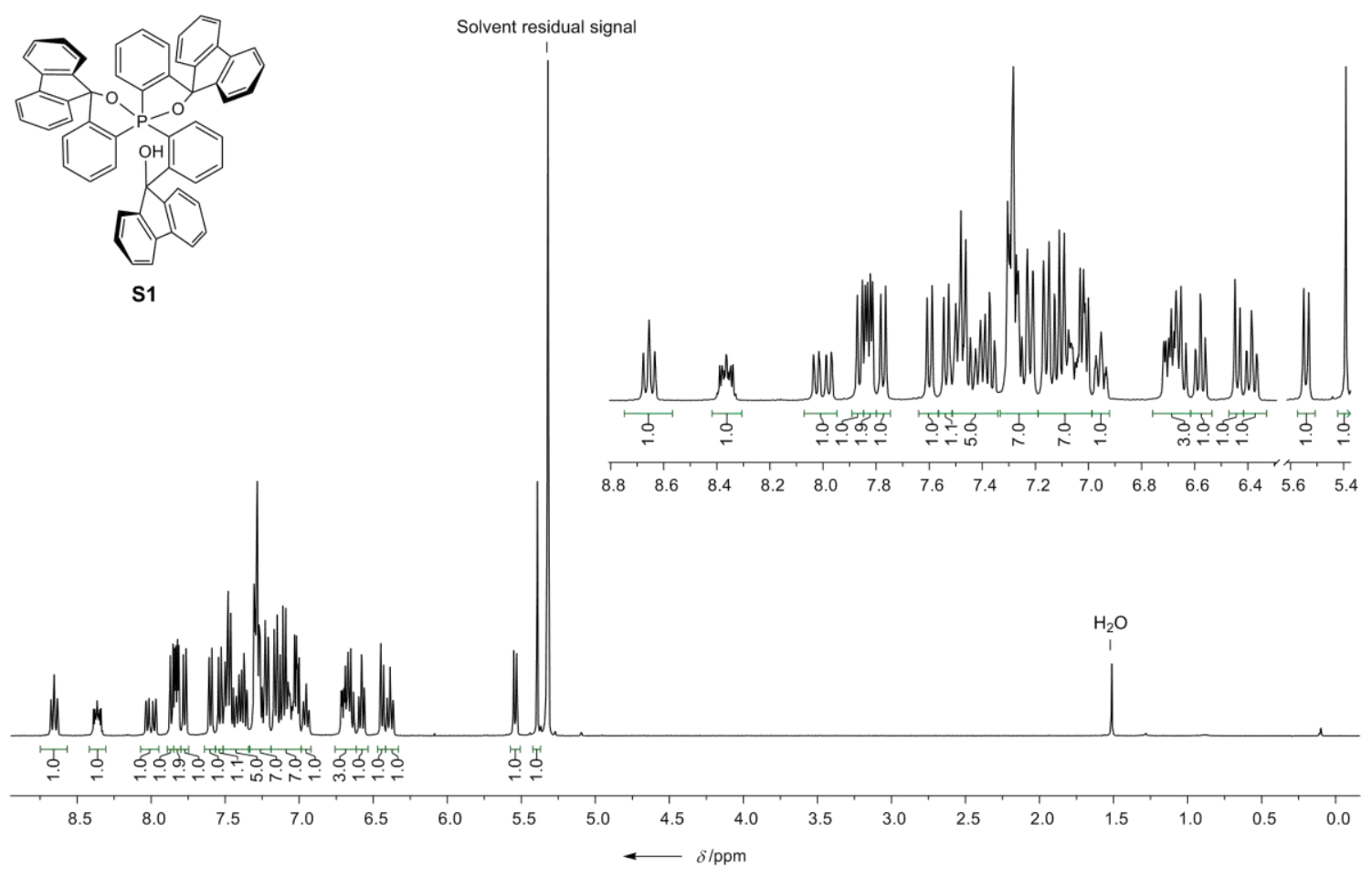

Figure S8. ${ }^{1} \mathrm{H}$ NMR spectrum $(400.1 \mathrm{MHz})$ of $\mathbf{S 1}$ in $\mathrm{CD}_{2} \mathrm{Cl}_{2}$ at $\mathrm{RT}$. 


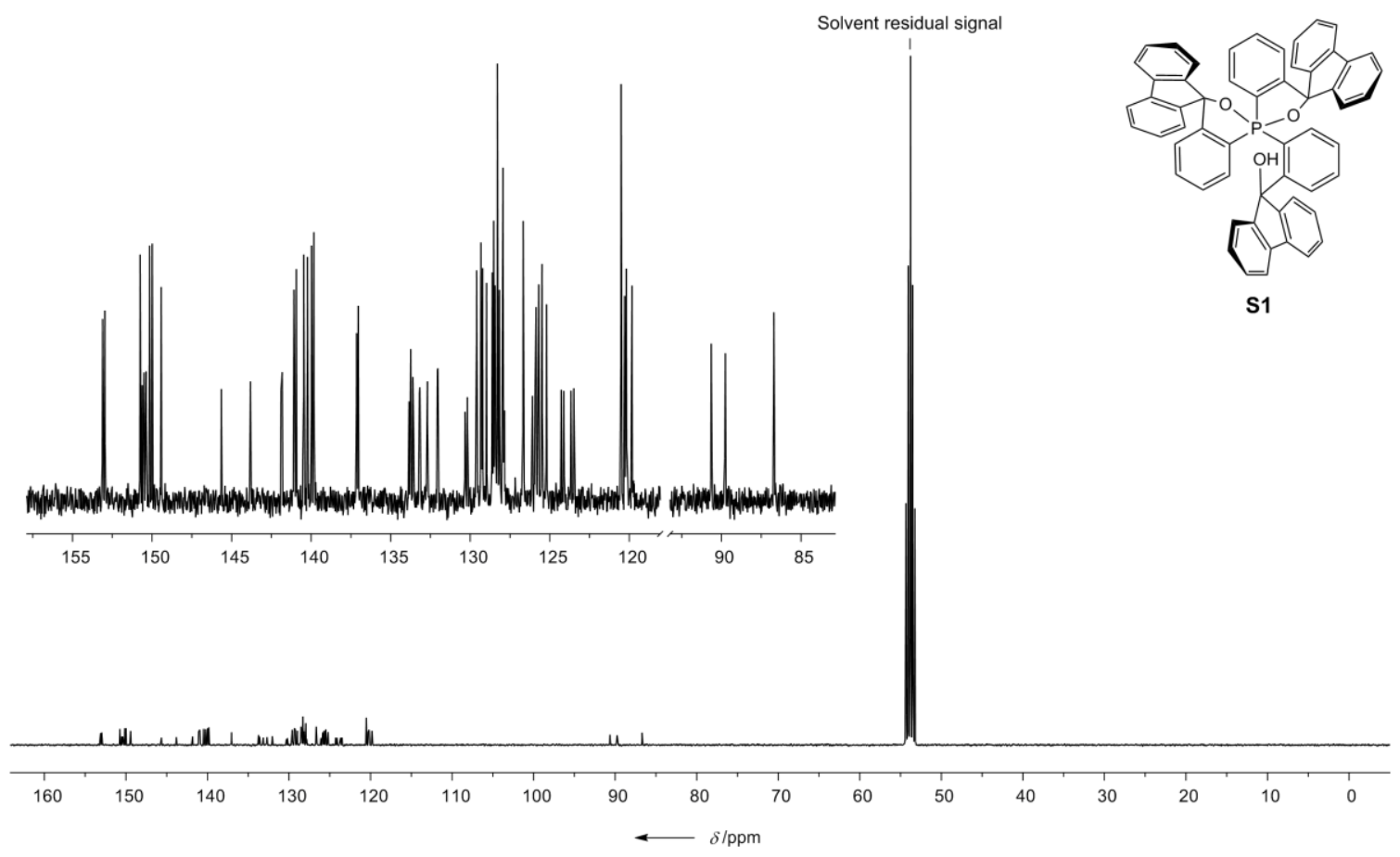

Figure S9. ${ }^{13} \mathrm{C}$ NMR spectrum $(100.6 \mathrm{MHz})$ of $\mathbf{S 1}$ in $\mathrm{CD}_{2} \mathrm{Cl}_{2}$ at RT.

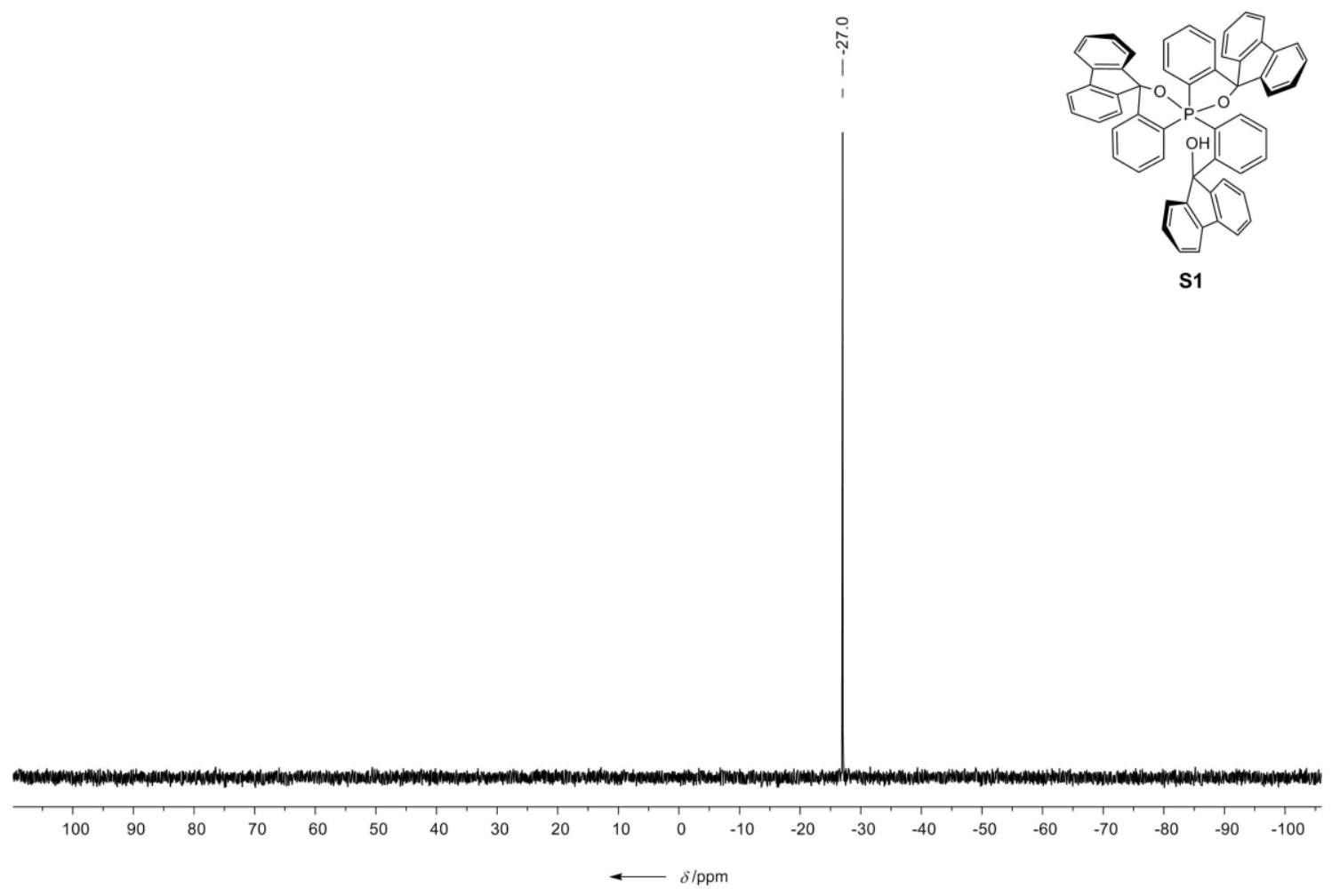

Figure S10. ${ }^{31} \mathrm{P}$ NMR spectrum $(162.0 \mathrm{MHz})$ of $\mathbf{S 1}$ in $\mathrm{CD}_{2} \mathrm{Cl}_{2}$ at RT. 


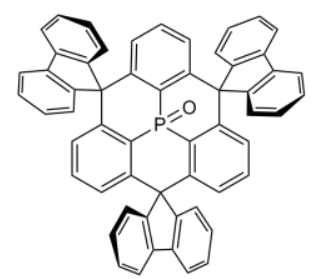

1

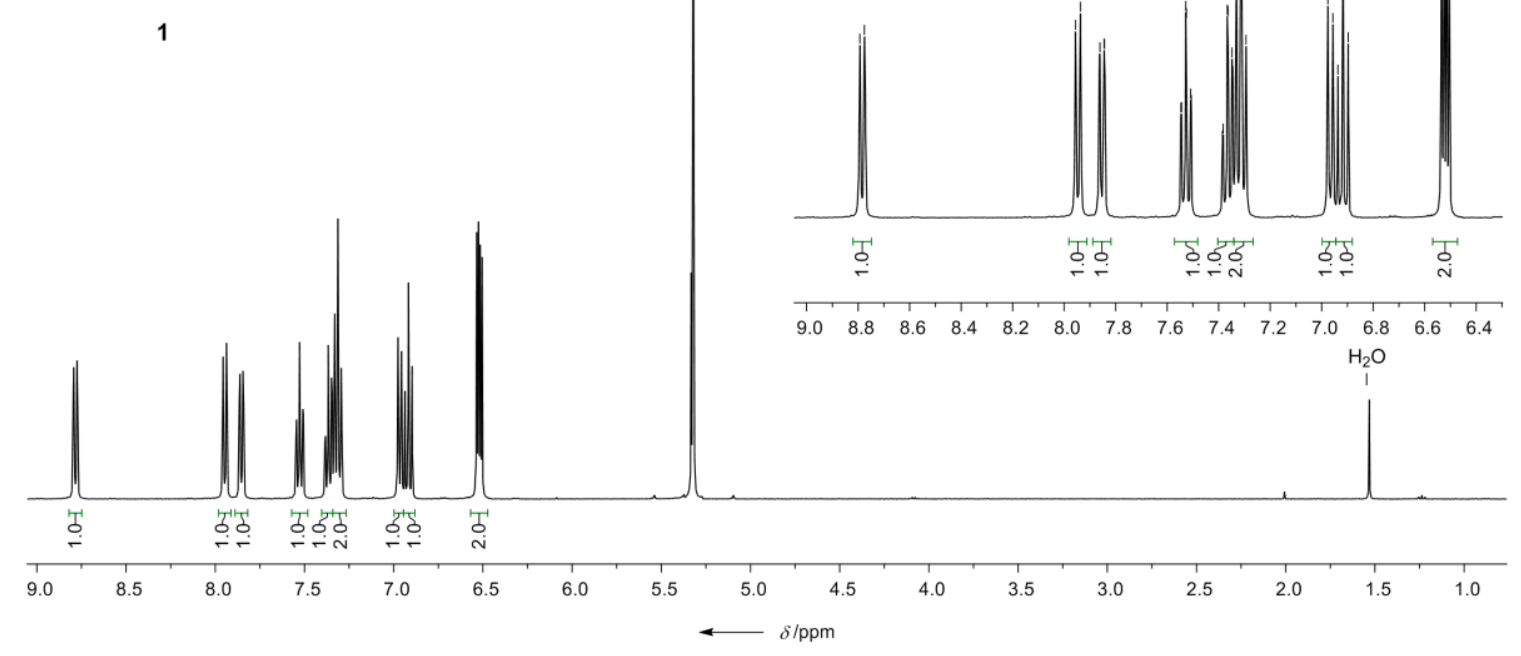

Figure S11. ${ }^{1} \mathrm{H}$ NMR spectrum (400.1 MHz) of $\mathbf{1}$ in $\mathrm{CD}_{2} \mathrm{Cl}_{2}$ at RT.

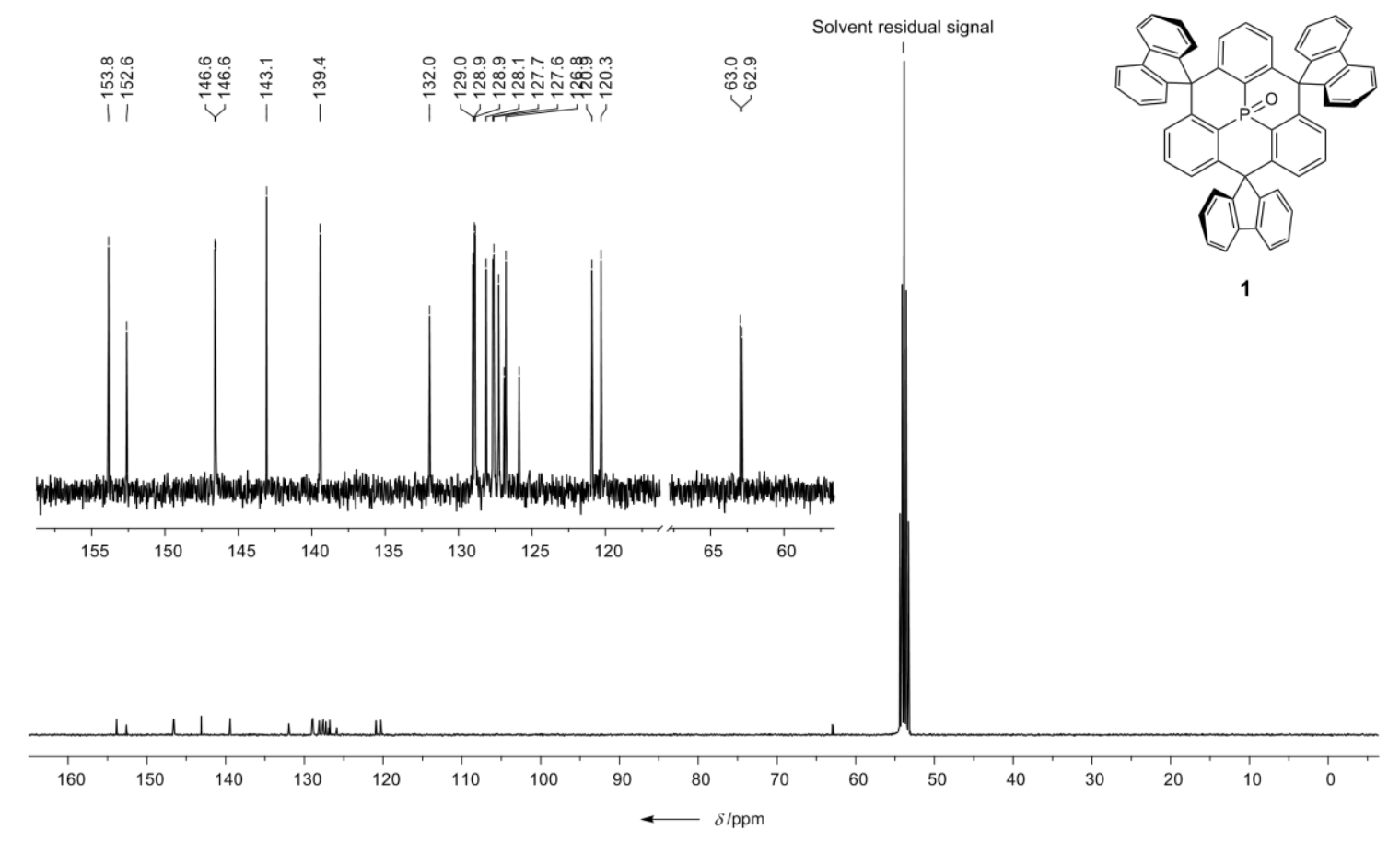

Figure S12. ${ }^{13} \mathrm{C}$ NMR spectrum $(100.6 \mathrm{MHz})$ of $\mathbf{1}$ in $\mathrm{CD}_{2} \mathrm{Cl}_{2}$ at $\mathrm{RT}$. 


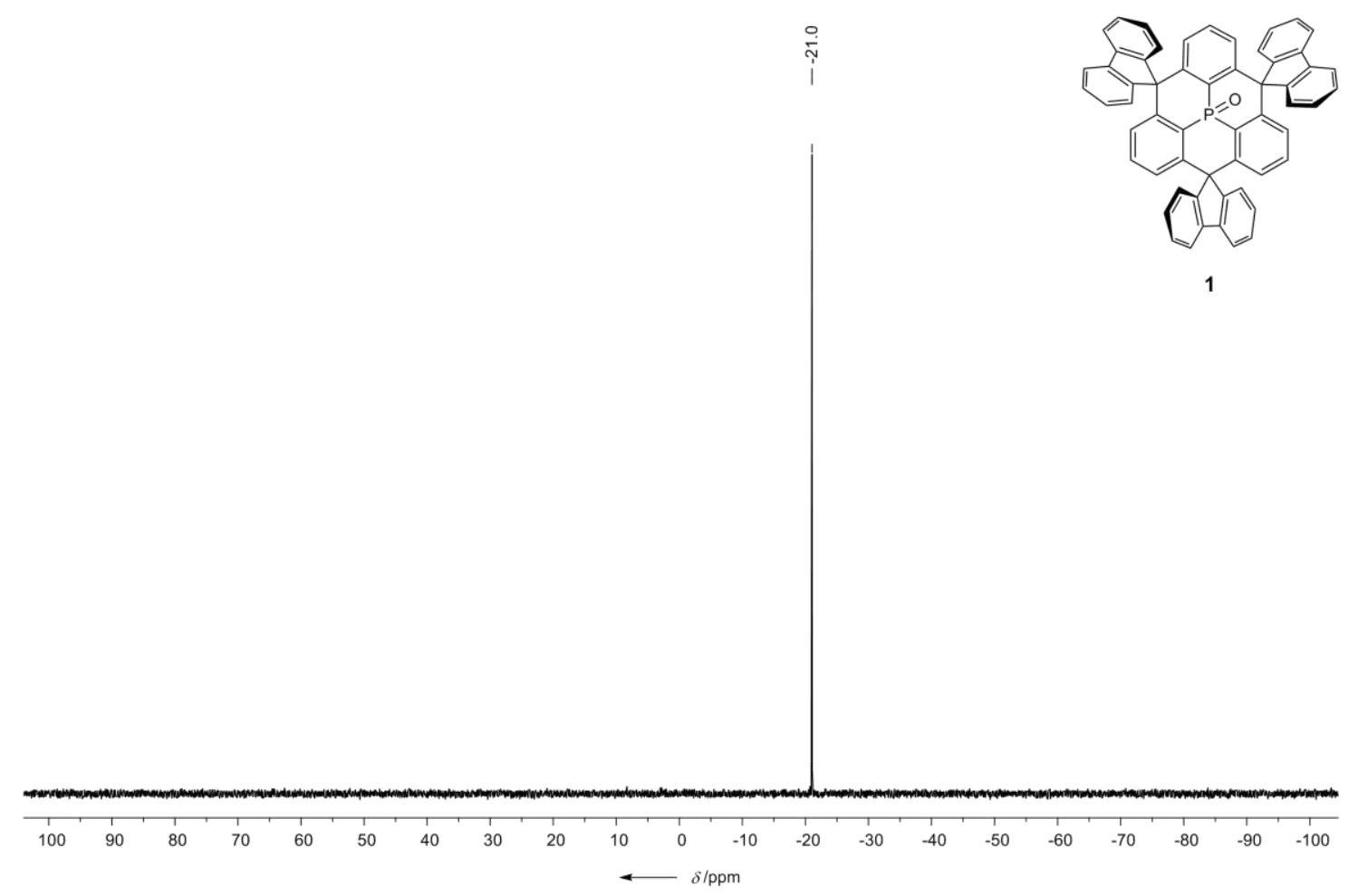

Figure S13. ${ }^{31} \mathrm{P}$ NMR spectrum $(162.0 \mathrm{MHz})$ of $\mathbf{1}$ in $\mathrm{CD}_{2} \mathrm{Cl}_{2}$ at $\mathrm{RT}$.

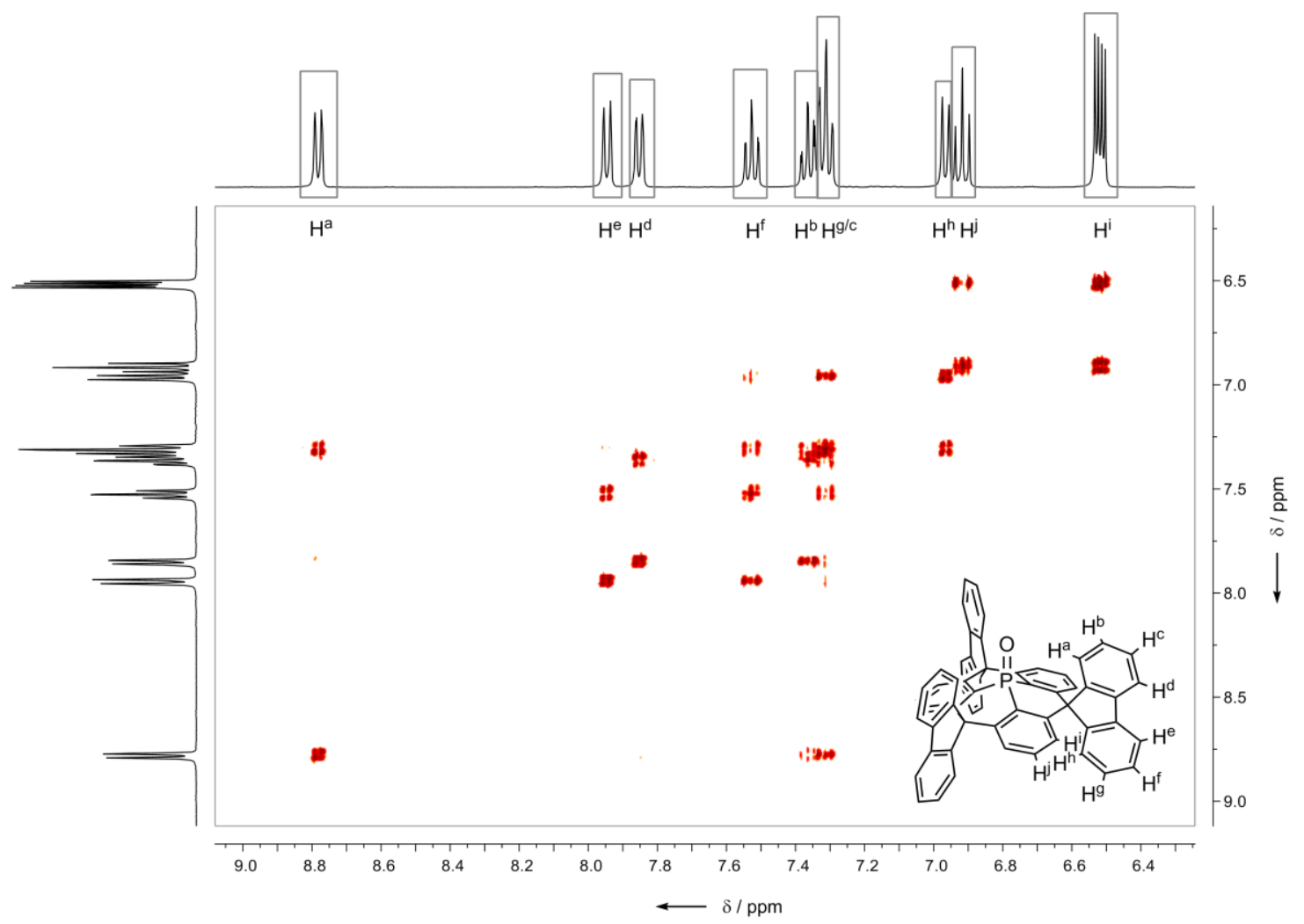

Figure S14. COSY 90 spectrum (400.1 MHz) of 1 in $\mathrm{CD}_{2} \mathrm{Cl}_{2}$ at RT. 


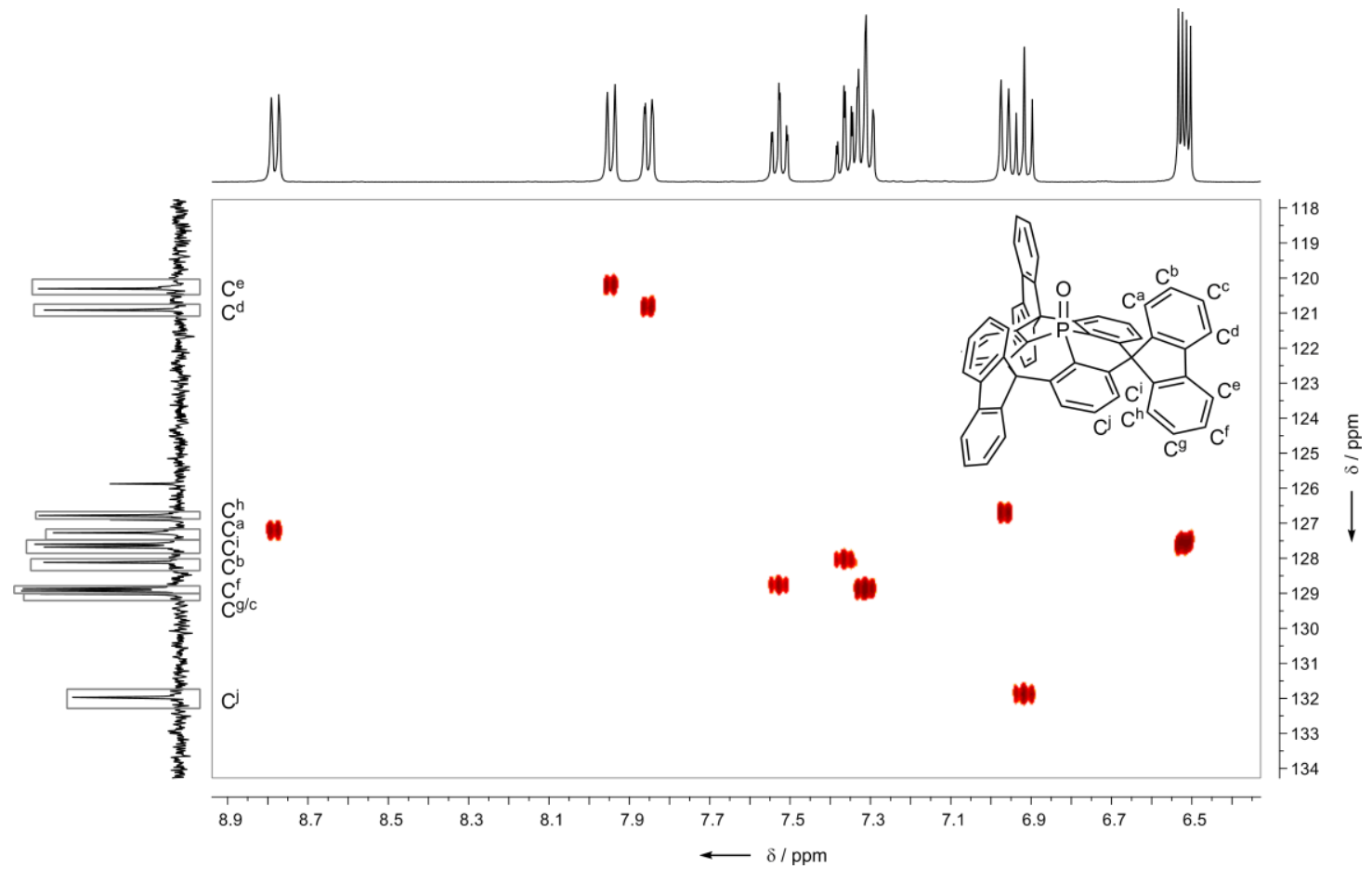

Figure S15. HSQC spectrum (400.1 MHz for ${ }^{1} \mathrm{H} / 100.6 \mathrm{MHz}$ for ${ }^{13} \mathrm{C}$ ) of $\mathbf{1}$ in $\mathrm{CD}_{2} \mathrm{Cl}_{2}$ at $\mathrm{RT}$; $\mathrm{C}^{\mathrm{i}}$ showed coupling with the ${ }^{31} \mathrm{P}$ nucleus.

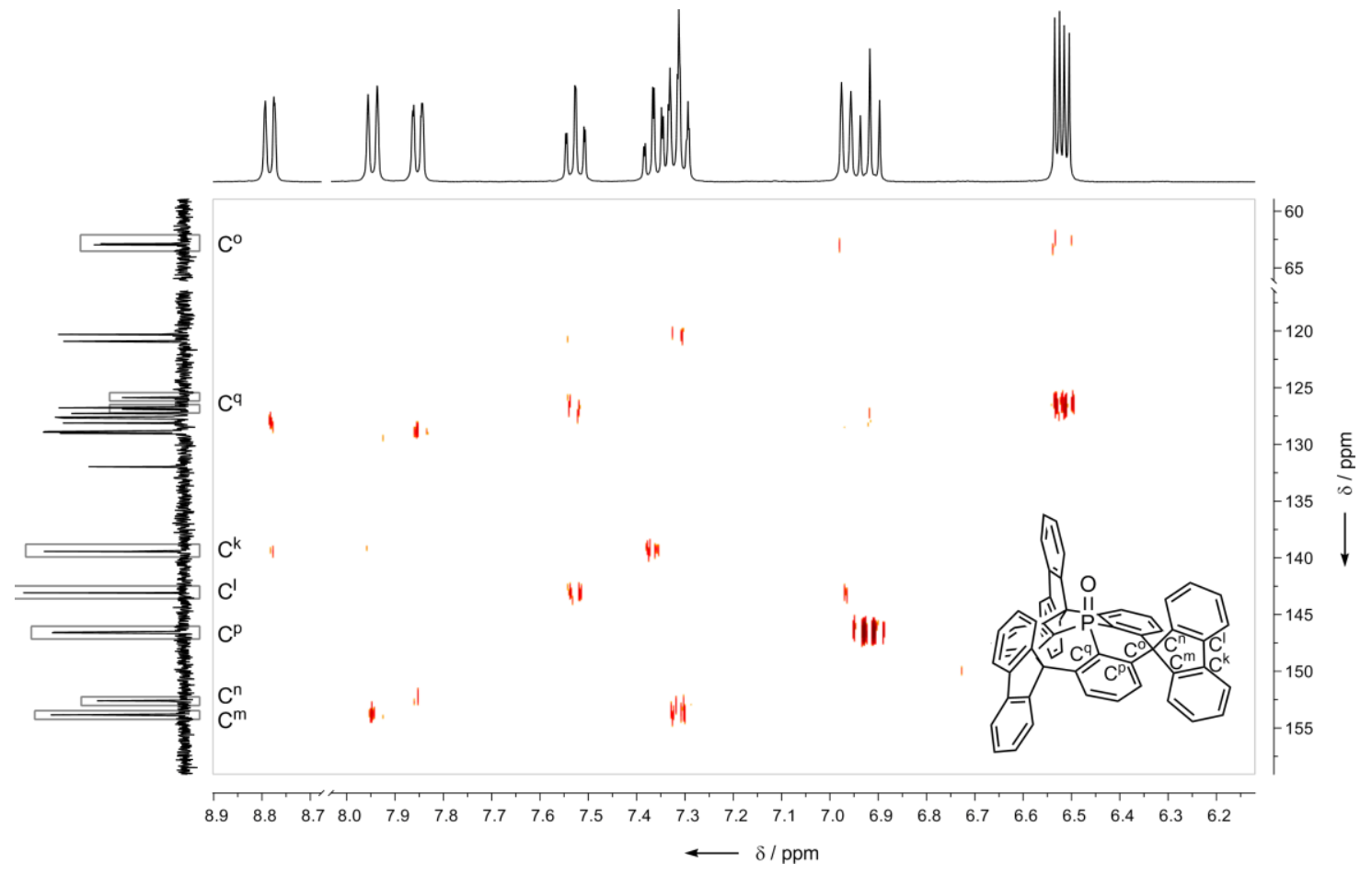

Figure S16. HMBC spectrum (400.1 MHz for ${ }^{1} \mathrm{H} / 100.6 \mathrm{MHz}$ for ${ }^{13} \mathrm{C}$ ) of $\mathbf{1}$ in $\mathrm{CD}_{2} \mathrm{Cl}_{2}$ at RT; Coupling with ${ }^{31} \mathrm{P}$ nucleus was observed for $\mathrm{C}^{\mathrm{q}}, \mathrm{C}^{\mathrm{p}}$, and $\mathrm{C}^{\mathrm{o}}$. 


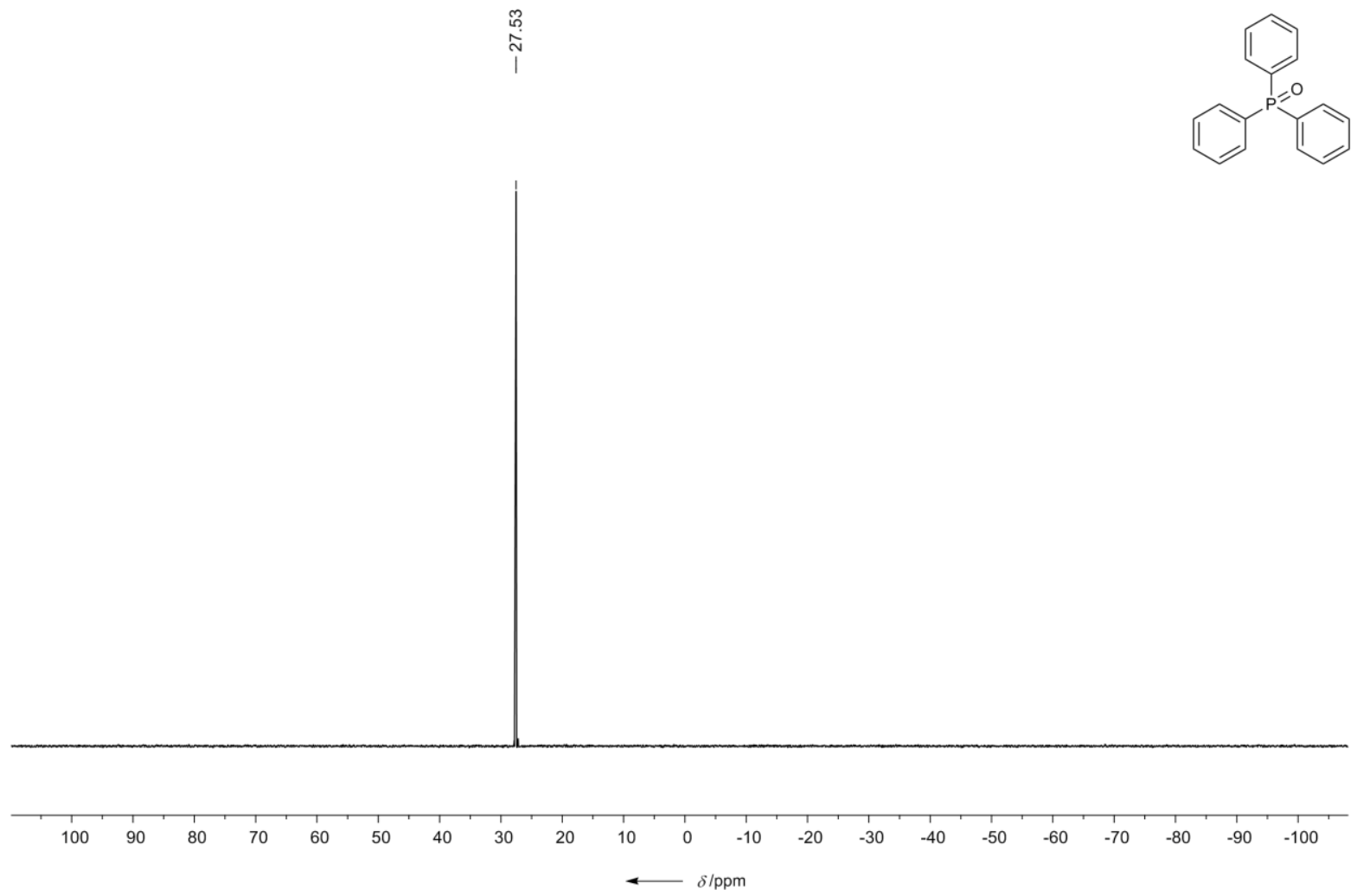

Figure S17. ${ }^{31} \mathrm{P}$ NMR spectrum (162.0 MHz) of $\mathrm{Ph}_{3} \mathrm{PO}$ in $\mathrm{CD}_{2} \mathrm{Cl}_{2}$ at $\mathrm{RT}$.

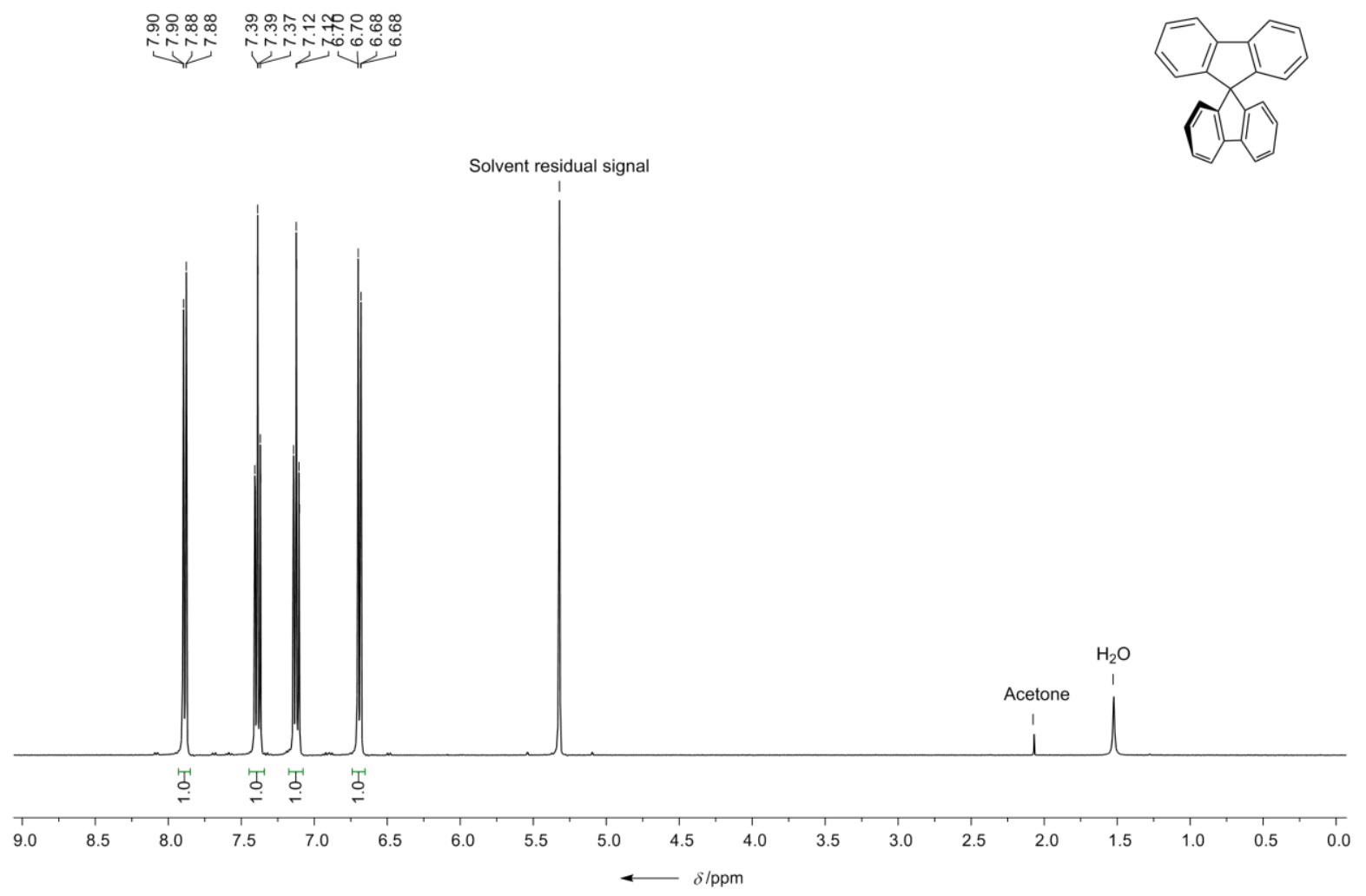

Figure S18. ${ }^{1} \mathrm{H}$ NMR spectrum (400.1 MHz) of 9,9'-spirobifluorene in $\mathrm{CD}_{2} \mathrm{Cl}_{2}$ at RT. 
The ${ }^{1} \mathrm{H}$ NMR spectrum (400 MHz) of 1 recorded in $\mathrm{CD}_{2} \mathrm{Cl}_{2}$ at $\mathrm{RT}$ shows ten well-resolved signals (Fig. S14), which were unambiguously assigned by 2D NMR spectroscopy. As a consequence of the intramolecular hydrogen bonding to the nearby phosphoryl oxygen atom the $\mathrm{H}^{\mathrm{a}}$ signal appears considerably deshielded at $8.78 \mathrm{ppm}$ when compared to the corresponding hydrogen atoms in, for instance, 9,9'-spirobifluorene, which resonate at $6.70 \mathrm{ppm}$ (Fig. S18). ${ }^{[8]}$ On the other hand, the protons $\mathrm{H}^{\mathrm{i}}(6.52 \mathrm{ppm})$ and $\mathrm{H}^{\mathrm{j}}(6.92 \mathrm{ppm})$ experience the shielding effect of the diamagnetic ring current of the neighbouring fluorenyl moieties as illustrated by the anisotropy of the induced current density (ACID) ${ }^{[9]}$ plot (Fig. S31). 


\section{X-Ray crystallographic analysis}

Compound 3. Single crystals of $\mathbf{3}$ suitable for X-ray crystallographic analysis were obtained by slow solvent evaporation of a solution of $\mathbf{3}$ in EtOAc at RT (Fig. S19). The racemic compound crystallizes in the centro-symmetric trigonal space group R-3 with 1/3 independent molecule 3 in the asymmetric unit. The asymmetric unit contains rest electron density from probably disordered $\mathrm{H}_{2} \mathrm{O}$ and the weak data did not allow a reasonable assignment of the atoms. Therefore, this area was masked during refinement (Squeeze). The masked void was calculated with 48.8 electrons per unit cell. The molecular structure of $\mathbf{3}$ shows a unique intramolecular coordination of the three equivalent hydroxyl groups to the P(III)-center with a distance of 1.906(2) $\AA$, which is, in analogy to the previously reported $N, N$-dimethylamino-substituted triarylphosphines, ${ }^{[10]}$ most likely facilitated by the rigid geometry of the peripheral fluorenyl moieties. The crystal data are as follows: Formula $\mathrm{C}_{57} \mathrm{H}_{39} \mathrm{O}_{3} \mathrm{P}$, formula weight $=802.85$, crystal size $0.208 \times 0.166 \times 0.152$ $\mathrm{mm}^{3}$, trigonal, $a=18.4874(15) \AA, b=18.4874(15) \AA, c=21.5378(14) \AA, \alpha=\beta=90^{\circ}, \gamma=120^{\circ}$, $V=6375.0(11) \AA^{3}, T=173.00(10) \mathrm{K}, Z=6, \rho_{\text {calcd }} 1.255 \mathrm{mg} \cdot \mathrm{mm}^{-3}, \mu\left(\mathrm{Cu} \mathrm{K} \mathrm{K}_{\alpha}\right)=0.936 \mathrm{~mm}^{-1}, 5613$ reflections measured, 2881 unique $\left(R_{\text {int }}=0.0249\right)$, which were used in all calculations. The final $w R_{2}$ was 0.2238 (all data) and $R_{1}$ was $0.0696(I>2 \sigma(I))$. CCDC number: 1420824 .
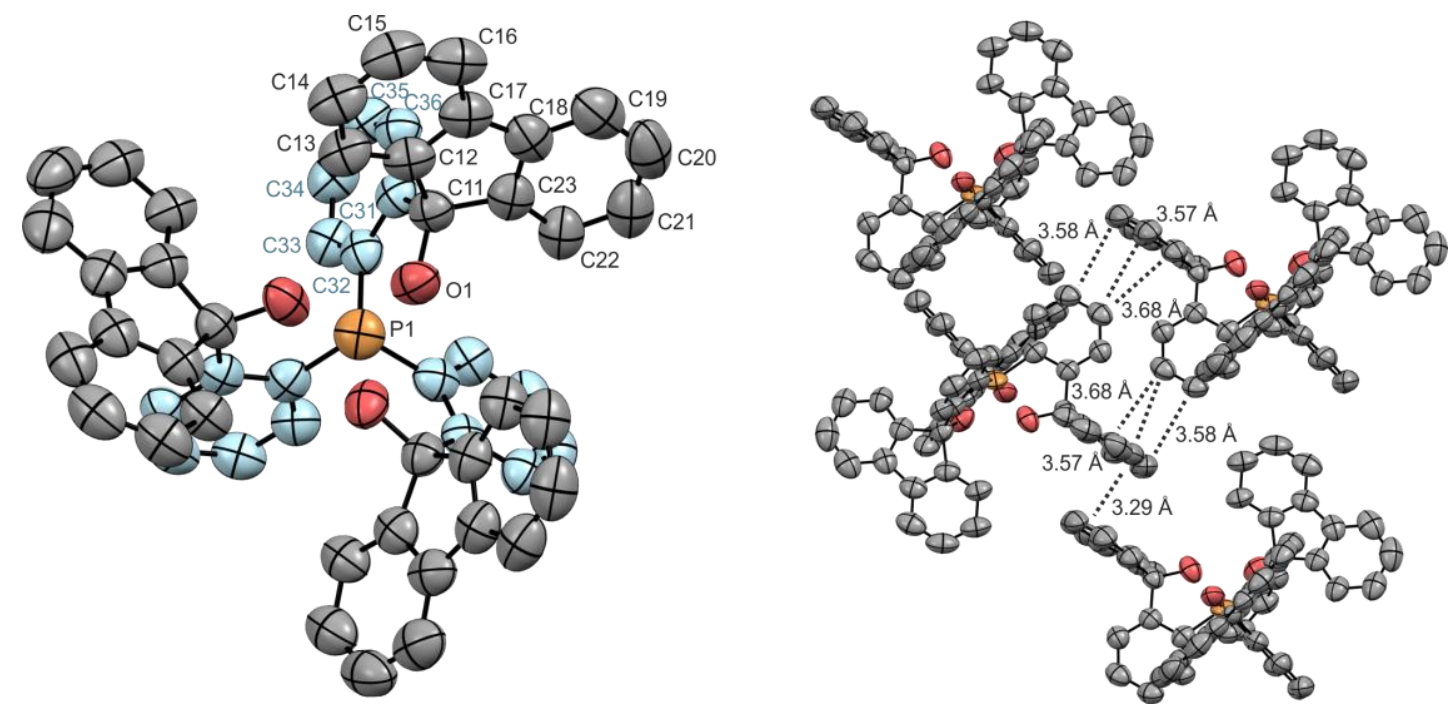

Figure S19. Molecular structure of one enantiomer of $\mathbf{3}$ (left) and packing (right) in the solid state (50\% probability level, $\mathrm{H}$-atoms are omitted and C-atoms in the back coloured light blue for clarity); Selected bond lengths and atom

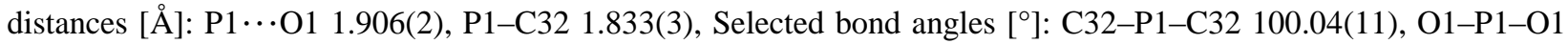
81.27(9); $\Sigma(\mathrm{C}-\mathrm{P}-\mathrm{C}) 300.12(33)$. 
Compound S1. Single crystals of S1 suitable for X-ray crystallographic analysis were obtained by slow diffusion of $n$-hexane into a solution of S1 in acetone at RT (Fig. S20). The racemic compound crystallizes in the centrosymmetric triclinic space group $P-1$ with one independent molecule $\mathbf{S 1}$ in the asymmetric unit. The asymmetric unit contains rest electron density from probably disordered solvent and the weak data did not allow a reasonable assignment of the atoms. Therefore, this area was masked during refinement (Squeeze). The masked void was calculated with 40.7 electrons per unit cell. In addition, 31 bad reflections with (error/esd) > 5 were removed for improving the data set quality. All other hydrogen atoms were placed in calculated positions using a riding model. The formation of compound S1 with its a P(V)-center was unambiguously confirmed by X-ray crystallography showing two covalent $\mathrm{P}-\mathrm{O}$ bonds (1.773(3) $\AA$ and 1.745(3) $\AA$ ) and a coordinated hydroxyl moiety with a P ...O distance of 2.309 $\AA$. The crystal data are as follows: Formula $\mathrm{C}_{57} \mathrm{H}_{37} \mathrm{O}_{3} \mathrm{P}$, formula weight $=800.83$, crystal size $0.190 \times 0.115 \times 0.060 \mathrm{~mm}^{3}$, triclinic, $a=12.7132(8) \AA, b=12.9458(7) \AA, c=12.9928(7) \AA, \alpha=$ $94.090(5)^{\circ}, \beta=93.595(5)^{\circ}, \gamma=90.226(5)^{\circ}, V=2128.7(2) \AA^{3}, T=173.00(14) \mathrm{K}, Z=2, \rho_{\text {calcd }}$ $1.249 \mathrm{mg} \cdot \mathrm{mm}^{-3}, \mu\left(\mathrm{Cu} \mathrm{K}_{\alpha}\right)=0.934 \mathrm{~mm}^{-1}, 9675$ reflections measured, 6348 unique $\left(R_{\text {int }}=0.0520\right)$, which were used in all calculations. The final $w R_{2}$ was 0.2439 (all data) and $R_{1}$ was $0.0792(I>$ $2 \sigma(I))$. CCDC number: 1420823.
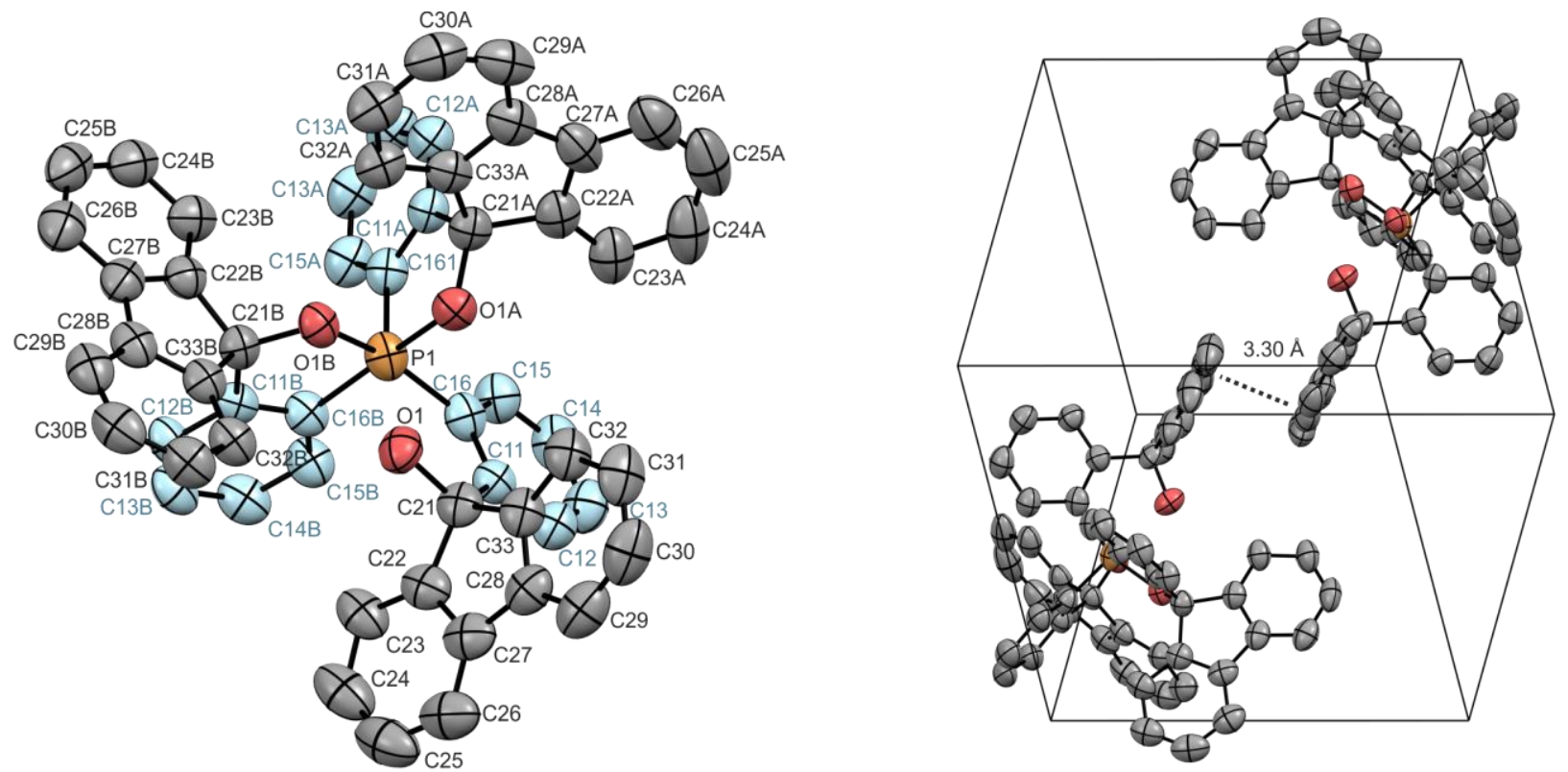

Figure S20. Molecular structure of the one enantiomer of S1 (left) and unit cell of the racemic compound containing the $P$ and $M$ enantiomer (right) in the solid state (50\% probability level, $\mathrm{H}$-atoms are omitted and $\mathrm{C}$-atoms in the

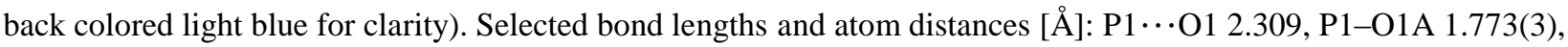


P1-O1B 1.745(3), P1-C16 1.847(4), P1-C16A 1.809(4), P1-C16B 1.845(4); Selected bond angles [ ${ }^{\circ}$ ]: C16A-P1C16 102.86(17), C16A-P1-C16B 100.84(17), C16B-P1-C16 95.27(17), O1A-P1-C16 90.05(17), O1A-P1-C16A 89.17(15), O1A-P1-C16B 167.29(15), O1B-P1-C16 156.68(15), O1B-P1-C16A 99.49(14), O1B-P1-C16B 86.96(14), O1B-P1-O1A 83.6(11); $($ (C-P-C) 298.97(51).

Compound 1. Single crystals of 1 suitable for X-ray crystallographic analysis were obtained by slow solvent evaporation of a solution of $\mathbf{1}$ in EtOAc at RT (Fig. S21). The compound crystallizes in the monoclinic space group $P 2_{1} / \mathrm{c}$ with one independent molecule $\mathbf{1}$ and two molecules of EtOAc in the asymmetric unit. The solvent molecules showed disorder, which has been resolved to the following occupation factors C200-C205:C206-C211 $=65: 35 \%$. The crystal data are as follows: Formula $\mathrm{C}_{65} \mathrm{H}_{48} \mathrm{O}_{5} \mathrm{P}$, formula weight $=940.00$, crystal size $0.252 \times 0.151 \times$ $0.127 \mathrm{~mm}^{3}$, monoclinic, $a=13.41607(15) \AA, b=21.5677(2) \AA, c=16.6002(2) \AA, \alpha=\gamma=90.00^{\circ}$, $\beta=97.1777(12)^{\circ}, V=4765.69(9) \AA^{3}, T=173.00(10), Z=4, \rho_{\text {calcd }} 1.310 \mathrm{mg} \cdot \mathrm{mm}^{-3}, \mu\left(\mathrm{Cu} \mathrm{K}_{\alpha}\right)=$ $0.946 \mathrm{~mm}^{-1}, 20042$ reflections measured, 9674 unique $\left(R_{\mathrm{int}}=0.0342\right)$, which were used in all calculations. The final $w R_{2}$ was 0.1549 (all data) and $R_{1}$ was $0.0548(I>2 \sigma(I))$. CCDC number: 1420825.
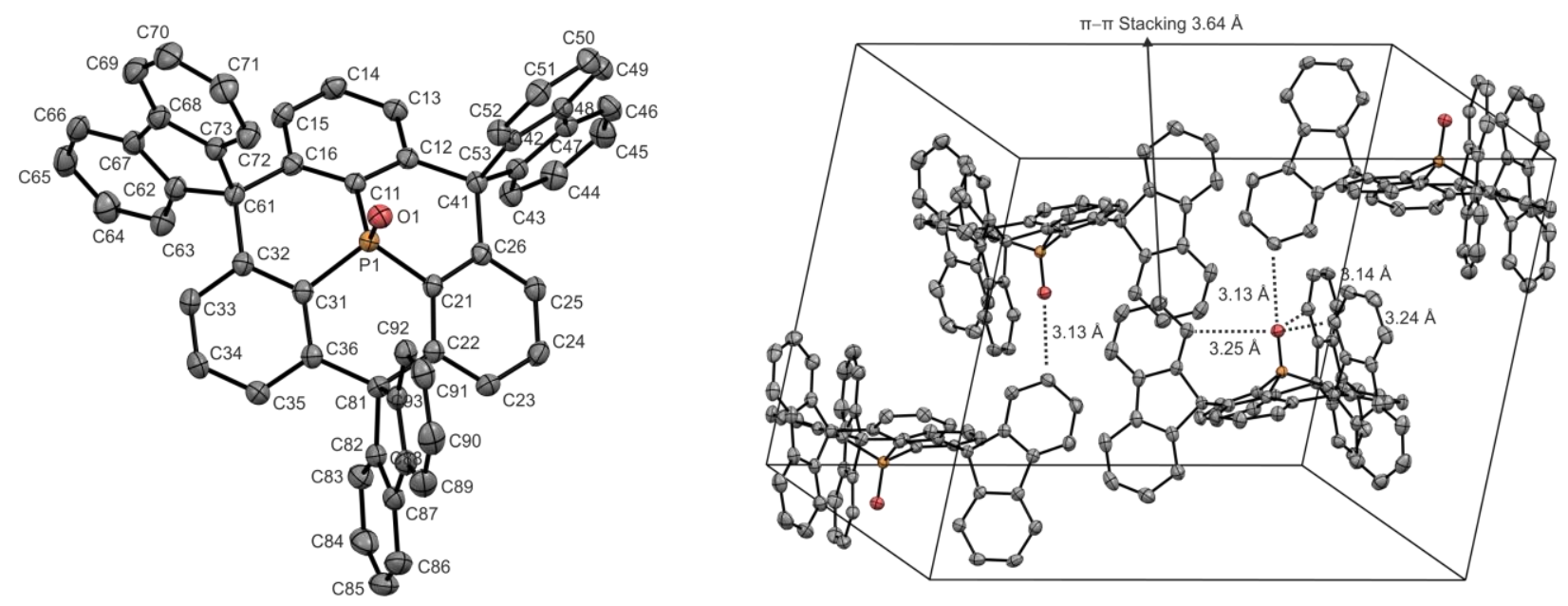

Figure S21. Molecular structure of $\mathbf{1}$ (left) and packing (right) in the solid state (50\% probability level, $\mathrm{H}$-atoms and EtOAc molecules are omitted for clarity); Selected bond lengths [̊̊]: P1-O1 1.4853(13), P1-C11 1.7628(17), P1C21 1.7655(17), P1-C31 1.7570(17), C11-C12 1.406(2), C12-C13 1.387(2), C13-C14 1.391(3), C14-C15 1.381(3), C15-C16 1.395(2), C11-C16 1.403(2), C16-C61 1.554(2); Selected bond angles []: C11-P1-C21 103.46(8), C31P1-C11 104.37(8), C31-P1-C21 104.87(8), P1-C11-C16 118.08(13), C11-C16-C61 122.79(15), C16-C61-C32 115.97(14), C12-C11-C16 123.29(15), C11-C16-C15 117.06(16), C16-C15-C14 120.54(16), C15-C14-C13 121.23(16); $\Sigma(\mathrm{C}-\mathrm{P}-\mathrm{C}) 312.70(24)$. 


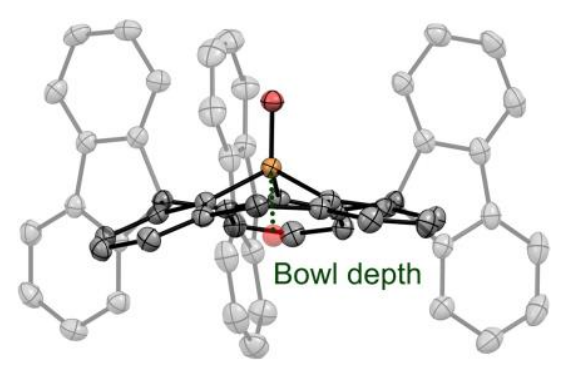

Figure S22. Illustration of the bowl depth (green dashed line), which is defined as the distance between the phosphorus atom and the centroid of the mean plane passing through the three para- $\mathrm{C}\left(\mathrm{sp}^{2}\right)$ atoms.

Radical anion $\mathbf{1}^{-}$. Single crystals of radical anion $\mathbf{1}^{-}[\mathrm{K} \subset 18 \text {-crown-6 }]^{+}$suitable for X-ray crystallographic analysis were obtained by slow diffusion of $n$-pentane into a solution of $\mathbf{1}^{-}[\mathrm{K} \subset 18 \text {-crown-6 }]^{+}$in $\mathrm{THF}$ at $-35^{\circ} \mathrm{C}$ in a glovebox within two weeks (Fig. S23). The compound crystallizes in the monoclinic space group $P 2_{1} / \mathrm{c}$ with one independent molecule 1- $^{-}[\mathrm{K} \subset 18 \text {-crown-6] }]^{+}$. The asymmetric unit contains four molecules of THF. The only moderate quality of the crystal combined with weak data did not allow an acceptable assignment and refinement of about 1.5 additional THF molecules. Therefore, this area was masked during refinement (Squeeze). The masked void was calculated with 215 electrons per unit cell, which is in good agreement with about 1.5 molecules of THF. In addition, no additional anion was found in this void, which unambiguously supports the presence of the anionic phosphine oxide radical. The crystal data are as follows: Formula $\mathrm{C}_{93} \mathrm{H}_{105} \mathrm{KO}_{13} \mathrm{P}$, formula weight $=1500.83$, crystal size $0.182 \times 0.122 \times 0.074 \mathrm{~mm}^{3}$, monoclinic, $a=15.3917(2) \AA, b=24.1445(3) \AA, c=24.2142(7) \AA$, $\alpha=\gamma=90.00^{\circ}, \beta=90.150(2)^{\circ}, V=8998.6(3) \AA^{3}, T=172.9(3), Z=4, \rho_{\text {calcd }} 1.108 \mathrm{mg} \cdot \mathrm{mm}^{-3}, \mu(\mathrm{Cu}$ $\left.\mathrm{K}_{\alpha}\right)=1.141 \mathrm{~mm}^{-1}, 11161$ reflections measured, 8853 unique $\left(R_{\text {int }}=0.0298\right)$, which were used in all calculations. The final $w R_{2}$ was 0.2414 (all data) and $R_{1}$ was $0.0782(I>2 \sigma(I))$. CCDC number: 1420826. 

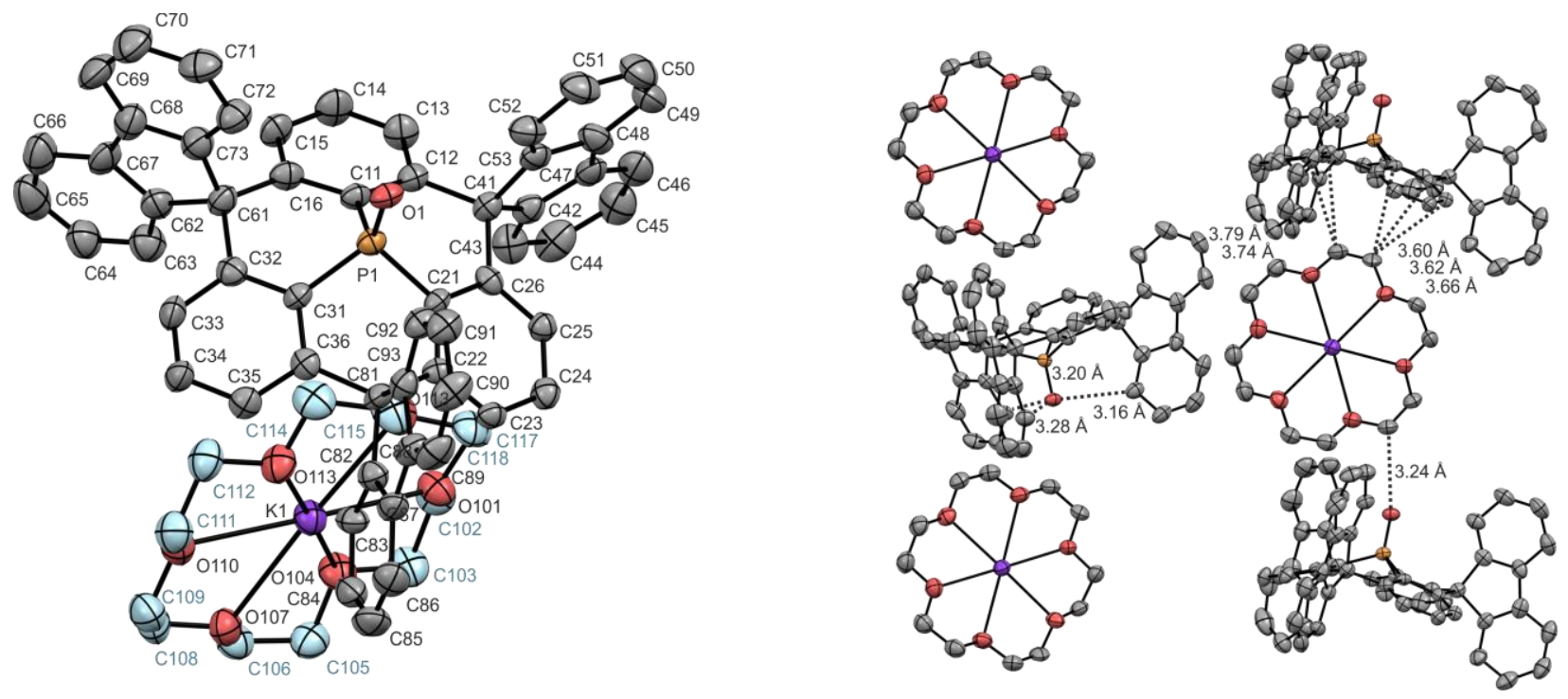

Figure S23. Molecular structure of $\mathbf{1}^{-}[\mathrm{K} \subset 18 \text {-crown-6 }]^{+}$(left) and packing (right) in the solid state (50\% probability level, $\mathrm{H}$-atoms and THF molecules are omitted for clarity; C-atoms of 18-crown-6 colored light blue). Selected bond lengths [̊̊]: P1-O1 1.492(3), P1-C11 1.742(4), P1-C21 1.750(5), P1-C31 1.751(3), C11-C12 1.424(5), C12-C13 1.377(6), C13-C14 1.386(7), C14-C15 1.401(6), C15-C16 1.386(6), C11-C16 1.408(6), C16-C61 1.549(5); Selected bond angles [ $\left.{ }^{\circ}\right]: C 11-P 1-C 21$ 102.7(2), C11-P1-C31 103.56(18), C21-P1-C31 102.43(19), P1-C11-C16 120.1(3), C11-C16-C61 121.8(3), C16-C61-C32 115.1(4), C12-C11-C16 120.1(3), C11-C16-C15 118.8(3), C14C15-C16 120.3(4), C13-C14-C15 120.9(4); (C-P-C) 308.69(57). 


\section{Thermogravimetric analysis}

Thermogravimetric analysis (TGA) of $\mathbf{1}$ revealed a remarkable increase of the decomposition temperature to $477{ }^{\circ} \mathrm{C}$ (Fig. S24) when compared to the decomposition temperature of triphenylphosphine oxide $\left(\mathrm{Ph}_{3} \mathrm{PO}\right)$ of $243{ }^{\circ} \mathrm{C}$ (decomposition temperature corresponding to $5 \%$ weight loss, Fig. S25).

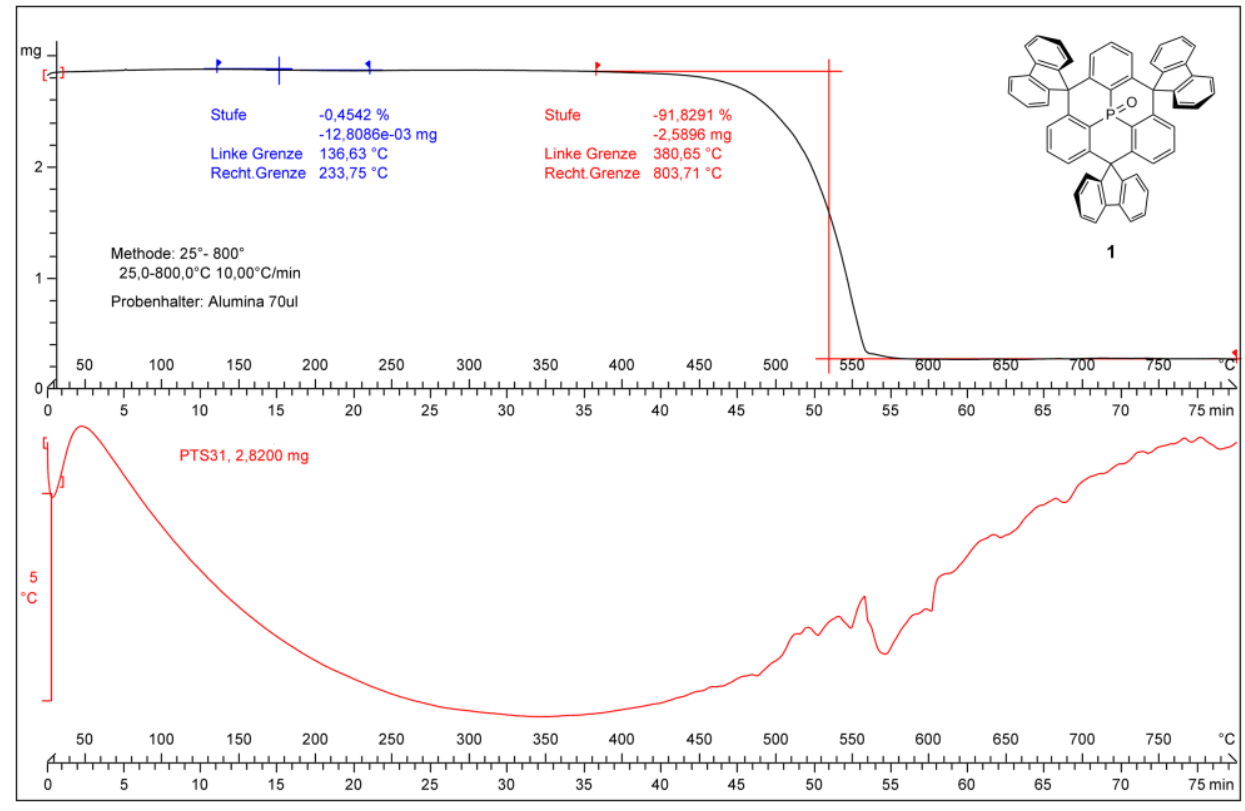

Figure S24. Thermogravimetric analysis of $\mathbf{1 .}$

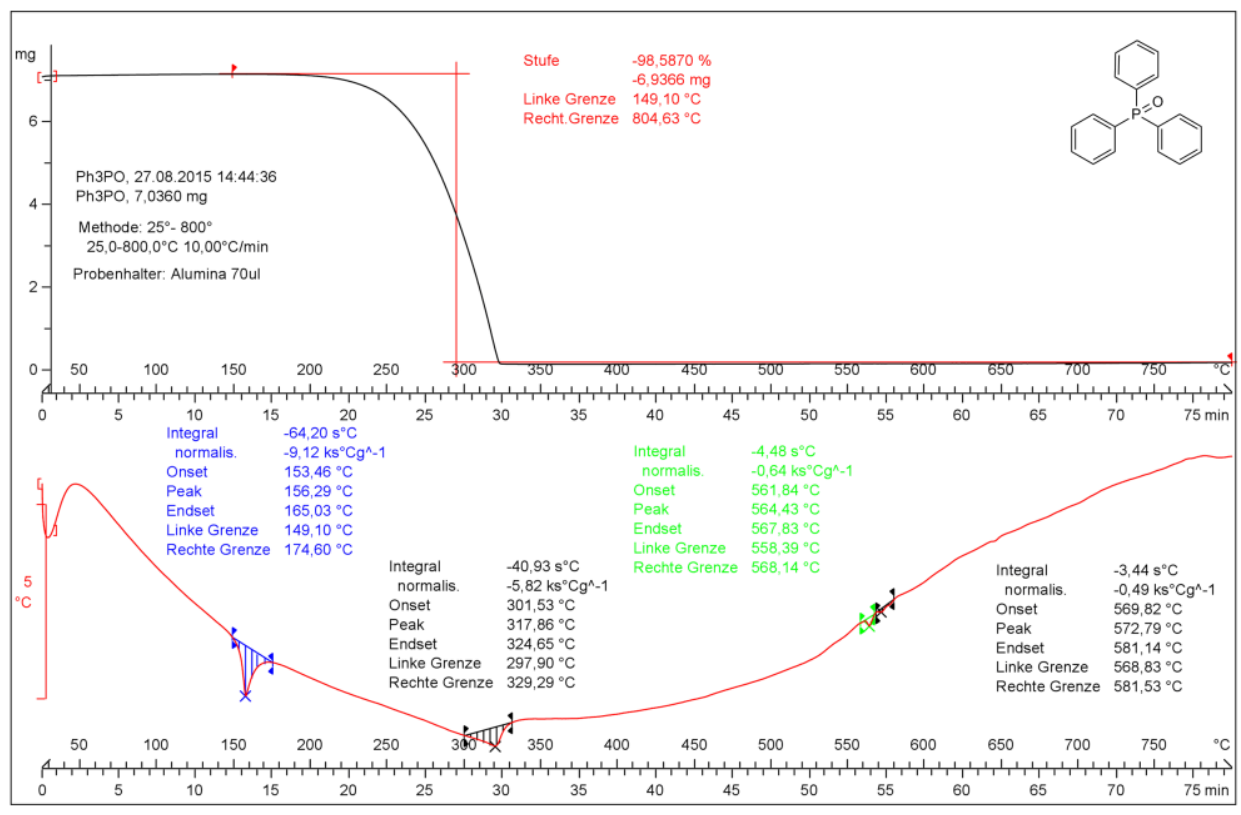

Figure S25. Thermogravimetric analysis of $\mathrm{Ph}_{3} \mathrm{PO}$. 


\section{Photophysical properties}

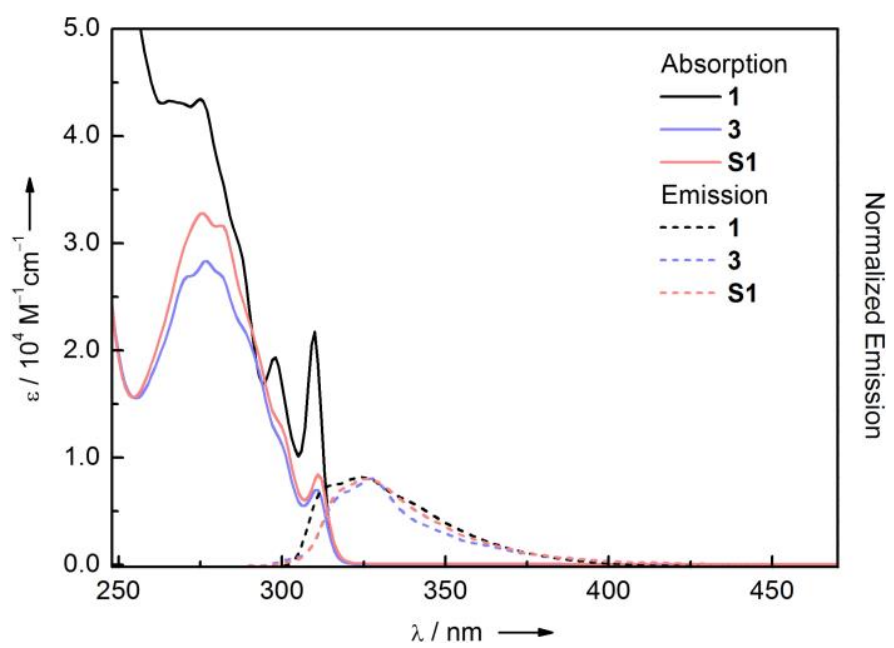

Figure S26. UV/vis absorption (solid lines) and normalized emission spectra (dashed lines, $\lambda_{\mathrm{ex}}=280 \mathrm{~nm}$ ) of 1 (black), $\mathbf{3}$ (blue), and $\mathbf{S 1}$ (red) in $\mathrm{CH}_{2} \mathrm{Cl}_{2}$ at RT; All three compounds show similar absorption and emission features which are characteristic for compounds containing the spirofluorene motif. ${ }^{[1]}$
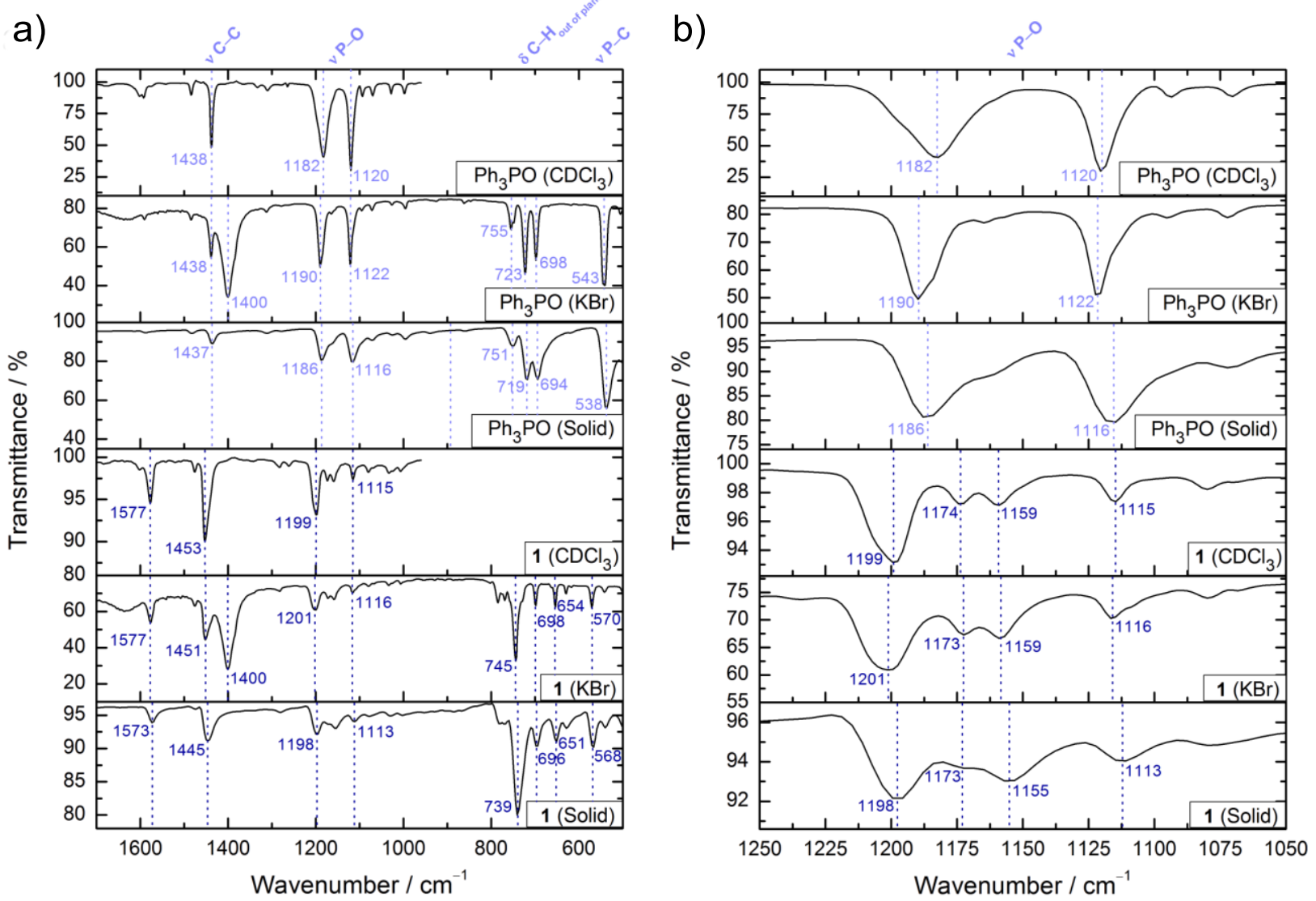

Figure S27. FTIR spectra of 1 and $\mathrm{Ph}_{3} \mathrm{PO}$ recorded in solution $\left(\mathrm{CDCl}_{3}\right), \mathrm{KBr}$ pellet and as powder (attenuated total reflection) at RT. a) Overview with assignment of the characteristic vibrations of $\mathrm{Ph}_{3} \mathrm{PO}^{[12]}$ b) Zoom-in into the region of the $v(\mathrm{P}-\mathrm{O})$ stretching frequency. 
Comparison of the FTIR spectra of $\mathrm{Ph}_{3} \mathrm{PO}$ and $\mathbf{1}$ indicate slight shifts of the characteristic vibration frequencies originating from the introduction of the $\mathrm{C}\left(\mathrm{sp}^{3}\right)$ spiro-fluorenyl bridges (Fig. $\mathrm{S} 27$ a). Hence, the $v(\mathrm{C}-\mathrm{C})$ stretching frequency is shifted from $1437-1438 \mathrm{~cm}^{-1}$ for $\mathrm{Ph}_{3} \mathrm{PO}$ to $1445-1453 \mathrm{~cm}^{-1}$ for $\mathbf{1}$. While the question of the exact assignment of the $v(\mathrm{P}-\mathrm{C})$ vibrations is still under debate ${ }^{[12]}$ we argue that the $v(\mathrm{P}-\mathrm{C})$ vibration of $\mathrm{Ph}_{3} \mathrm{PO}$ at $538-543 \mathrm{~cm}^{-1}$ most likely appears at higher frequencies for 1 at $568-570 \mathrm{~cm}^{-1}$ indicating an increase in the $\mathrm{P}-\mathrm{C}$ bond strength as also observed in the corresponding X-ray crystal structure. The $v(\mathrm{P}-\mathrm{O})$ stretching frequencies of triarylphosphine oxides have been reported to be rather sensitive to the extent of intermolecular interactions in solution and in the solid state. ${ }^{[13]}$ Accordingly, the $v(\mathrm{P}-\mathrm{O})$ frequency for $\mathrm{Ph}_{3} \mathrm{PO}$ shifts from $1116 \mathrm{~cm}^{-1}$ measured as solid to $1120 \mathrm{~cm}^{-1}$ in solution $\left(\mathrm{CDCl}_{3}\right)$, and $1122 \mathrm{~cm}^{-1}$ in $\mathrm{KBr}$ pellet. In the case of compound $\mathbf{1}$ we observe a splitting of the characteristic doublet band as seen for $\mathrm{Ph}_{3} \mathrm{PO}$ (Fig. S27b) impeding the assignment of the corresponding $v(\mathrm{P}-\mathrm{O})$ band. A similar splitting was also observed for complexes of $\mathrm{Ph}_{3} \mathrm{PO}$ with various metal centers producing separate symmetric and asymmetric stretching modes. ${ }^{[14]} \mathrm{We}$ assume, that an analogous splitting of the characteristic $v(\mathrm{P}-\mathrm{O})$ doublet band in $\mathbf{1}$ is the result of the intramolecular hydrogen-bonding with the phosphoryl oxygen-atom $\mathrm{C}\left(\mathrm{sp}^{2}\right)-\mathrm{H} \cdots \mathrm{O}$ as evidenced by ${ }^{1} \mathrm{H}$ NMR spectroscopy in combination with X-ray crystallography and theoretical calculations. 


\section{Cyclic voltammetry measurements}

Phosphine oxide 1 shows two different electrochemical events in cyclic voltammetry experiments, namely the reduction of the phosphine oxide moiety (only in THF) and the oxidation of the fluorenyl moieties (only in $\mathrm{CH}_{2} \mathrm{Cl}_{2}$ ). While in $\mathrm{CH}_{2} \mathrm{Cl}_{2}$ even at very low potentials $(-2.80 \mathrm{~V})$ with different scan rates no reduction was detected (Fig. S28), oxidation of the fluorenyl moieties was observed at a half-wave potential of $1.435 \mathrm{~V}$ vs. $\mathrm{Fc} / \mathrm{Fc}^{+}$(Fig. S29, black and blue trace, right feature). Under the premise that $\mathrm{Fc} / \mathrm{Fc}^{+}$is $-4.8 \mathrm{eV}$ vs. vacuum level ${ }^{[15]}$ the HOMO level is estimated to be $-6.24 \mathrm{eV}$, which is in excellent agreement with the theoretical predictions ( $\mathrm{E}_{\text {Hомо }}-6.24 \mathrm{eV}$ ). Oxidation of the fluorenyl moieties results in the formation of an electroactive polymer, deposited as a film on the working electrode. Reduction of this film appears during first scan (Fig. S29, black trace, left feature) and oxidation of the electroactive film takes place during second scan for the first time (Fig. S29, blue trace, left feature). This reactivity was previously reported in the literature for different kinds of fluorenyl-containing compounds ${ }^{[16]}$. The polymeric film shows oxidation events between $0.770-1.350 \mathrm{~V}$ vs. $\mathrm{Fc} / \mathrm{Fc}^{+}$ and reduction events between $0.620-1.170 \mathrm{~V}$ vs. $\mathrm{Fc} / \mathrm{Fc}^{+}$(blue trace, left feature). Without the fluorenyl oxidation, no redox events of the polymer arise during 10 cycles (red trace). As the thickness of the electroactive film is dependent on the scan rate, scan rate dependency is difficult to access, but hints at the fluorenyl oxidation to be a diffusion controlled "in solution" event. Further investigations of the formed polymeric film will be part of our future work.

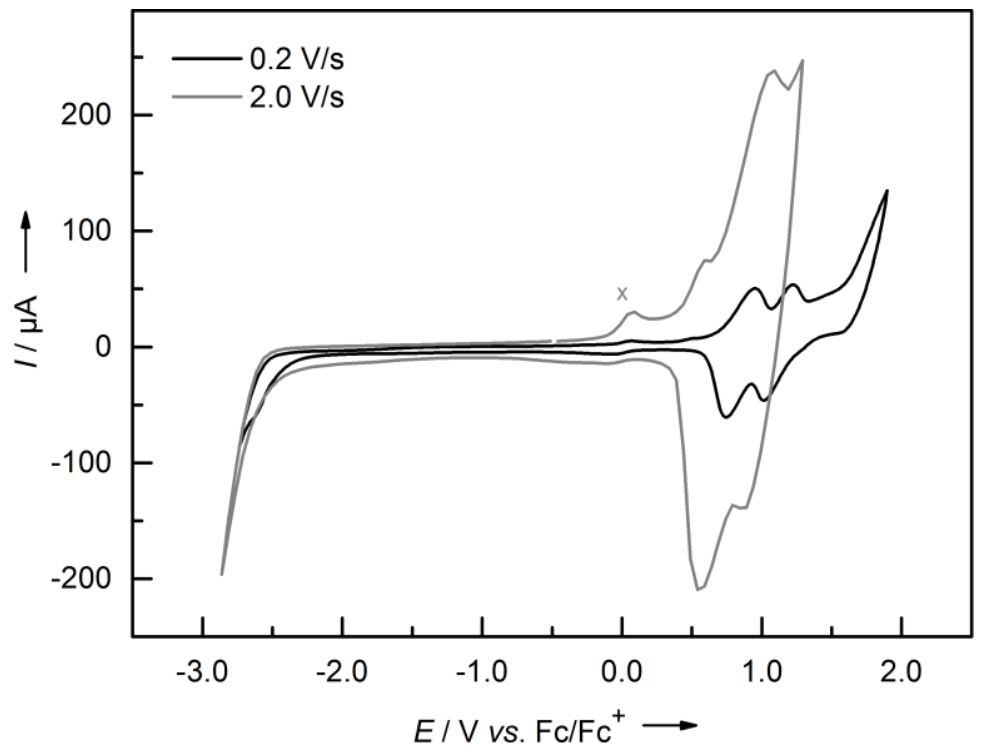

Figure S28. Cyclic voltammograms of $1\left(0.5 \mathrm{mM}\right.$ in $\mathrm{CH}_{2} \mathrm{Cl}_{2}$ with $0.1 \mathrm{M} n \mathrm{Bu}_{4} \mathrm{NPF}_{6}$, glassy carbon working electrode) at different scan rates. $\mathrm{x}$-Labeled signals are ascribed to the internal $\mathrm{Fc}^{+} / \mathrm{Fc}$ reference. 


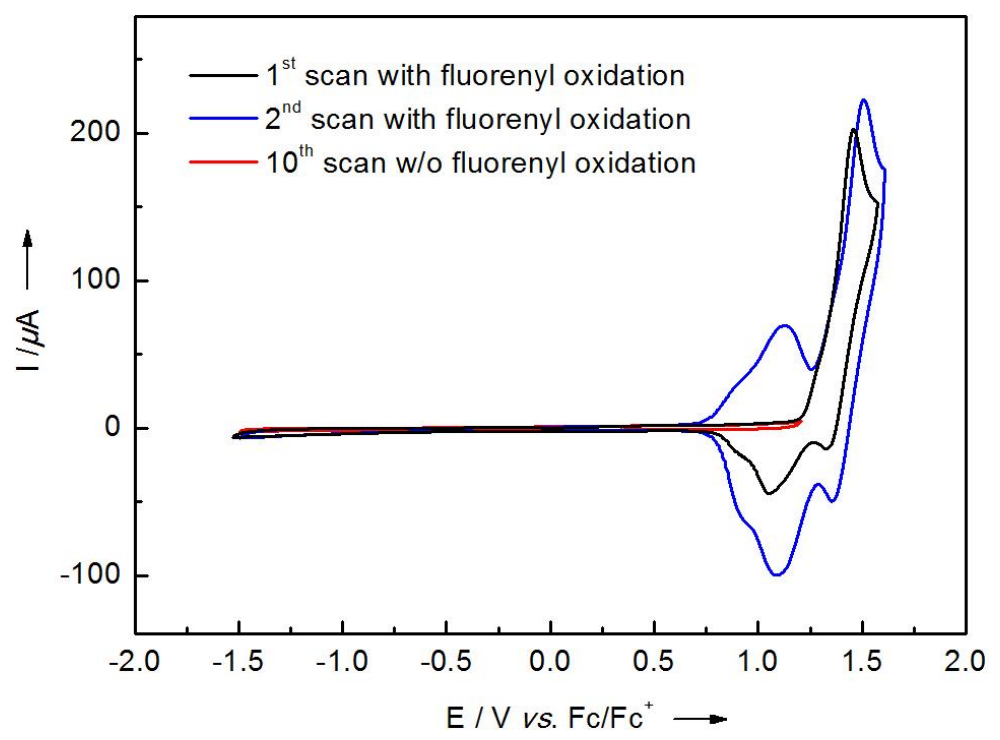

Figure S29. Cyclic voltammograms of $1\left(0.5 \mathrm{mM}\right.$ in $\mathrm{CH}_{2} \mathrm{Cl}_{2}$ with $0.1 \mathrm{M} n \mathrm{Bu}_{4} \mathrm{NPF}_{6}$, glassy carbon working electrode, scan rate $200 \mathrm{mV} / \mathrm{s}$ ). Oxidation of the fluorenyl moieties (black and blue traces, right feature) gives rise to the formation of an electroactive polymer film, which is deposited on the electrode (blue trace, left feature). No redox events of the polymer were observed during 10 cycles when omitting the fluorenyl oxidation (red trace).
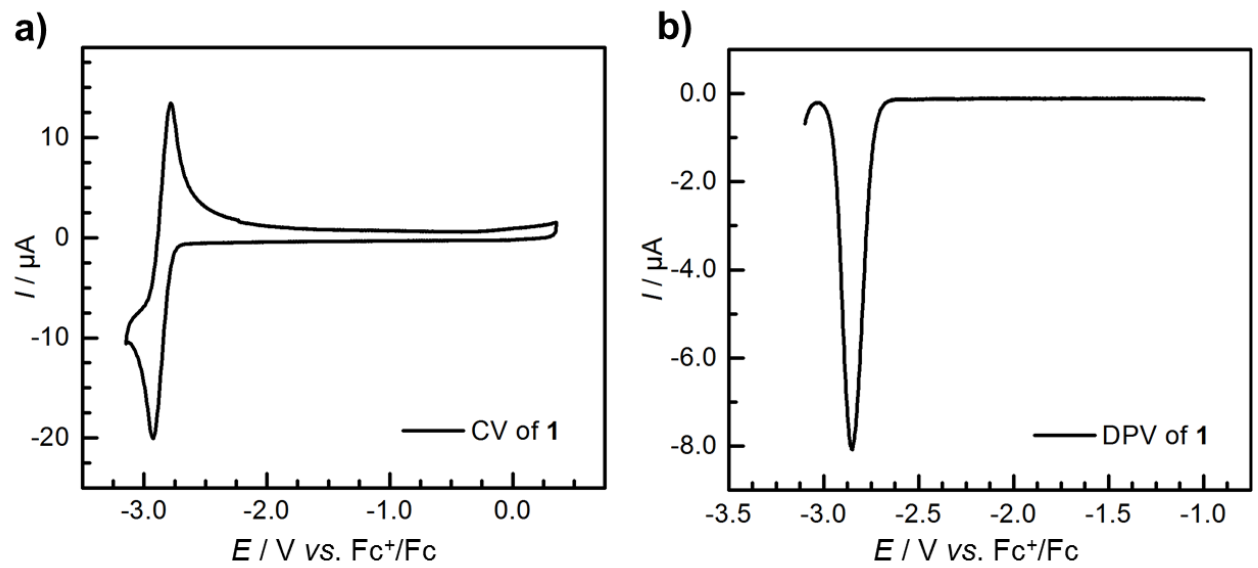

Figure S30. a) Cyclic voltammogram of $\mathbf{1}\left(0.5 \mathrm{mM}\right.$ in THF with $0.1 \mathrm{M} n \mathrm{Bu}_{4} \mathrm{NPF}_{6}$, glassy carbon working electrode,

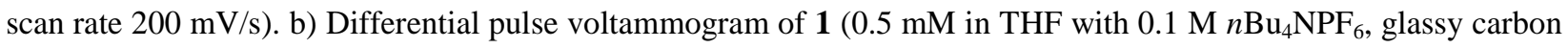
working electrode, scan rate $200 \mathrm{mV} / \mathrm{s}$ ). Both methods identified the reversible reduction of the $\mathrm{P}=\mathrm{O}$ moiety occurring at $-2.85 \mathrm{~V}\left(v s . \mathrm{Fc}^{+} / \mathrm{Fc}\right)$. 


\section{Electron paramagnetic resonance measurements}

As to demonstrate the stabilizing effect of the spiro-fluorenyl tethers in $\mathbf{1}$ towards one-electron reduction we conducted EPR measurements of the radical anions of $\mathrm{Ph}_{3} \mathrm{PO}$, which was obtained following the procedure for the preparation of $\mathbf{1}^{-}$. In contrast of observations of Evans et al., ${ }^{[17]}$ the EPR spectrum of the chemical reduction of $\mathrm{Ph}_{3} \mathrm{PO}$ with potassium shows two radical species with only poorly resolved hyperfine splitting to the protons and hyperfine coupling constants $A\left({ }^{31} \mathrm{P}\right)$ of $25.9 \mathrm{MHz}(0.93 \mathrm{mT})$ and $59.9 \mathrm{MHz}(2.14 \mathrm{mT}),{ }^{[18]}$ which are smaller than that observed for $1^{--}$with $A\left({ }^{31} \mathrm{P}\right)$ of $99.9 \mathrm{MHz}(3.57 \mathrm{mT})$, likely due to the interaction of the alkali cation with the $\mathrm{Ph}_{3} \mathrm{PO}$ derived radicals at RT (Fig S31). On the basis of our results the radical species could not be assigned to a specific structure, however, in both cases, less spin density is on the internal phosphorus atom, which is in agreement with the considerably smaller hyperfine coupling with the internal ${ }^{31} \mathrm{P}$ atom $(\mathrm{I}=1 / 2,100 \%)$ expected for the radical anion of $\mathrm{Ph}_{3} \mathrm{PO} A\left({ }^{31} \mathrm{P}\right)$ of $25.9 \mathrm{MHz}$ $(0.93 \mathrm{mT})$ and some decomposition product resulting from phenyl ring cleavage $A\left({ }^{31} \mathrm{P}\right)$ of 59.9 $\mathrm{MHz}(2.14 \mathrm{mT})^{[19]}$. The addition of [2.2.2]cryptand did not further increase the resolution of the EPR spectrum. Instead, the signal was completely quenched, indicating that the $\mathrm{Ph}_{3} \mathrm{PO}$ radical itself is not persistent without the stabilizing interaction of the potassium cation. In contrast to stable $\mathbf{1}^{-}$in which the tethered triphenylphosphine oxide core provides for efficient delocalization of the spin population, such interaction in $\mathrm{Ph}_{3} \mathrm{PO}$ is considerably less pronounced and hence most likely insufficient to stabilize the radical anion on its own.

Table S1. Experimental and theoretical hyperfine coupling constants $A[\mathrm{mT}]$ from DFT calculations of $\mathbf{1}^{\bullet-}$ and Mulliken spin densities $\rho$ [au] for selected atoms; Deviation from $C_{3}$ symmetry leads to variations for the calculated values.

Atom

\begin{tabular}{|c|c|c|c|c|}
\hline & & $P$ & $\mathrm{H}_{p}$ & $\mathrm{H}_{m}$ \\
\hline \multirow{2}{*}{$\boldsymbol{A}$} & Exp. & 3.57 & 0.32 & Not observed \\
\hline & Theo. & 3.60 & $-0.25,-0.30,-0.32$ & Six values ranging from 0.03 to 0.08 \\
\hline$\rho$ & Theo. & 0.12 & $-0.014,-0.014,-0.014$ & Six values ranging from 0.001 to 0.002 \\
\hline
\end{tabular}




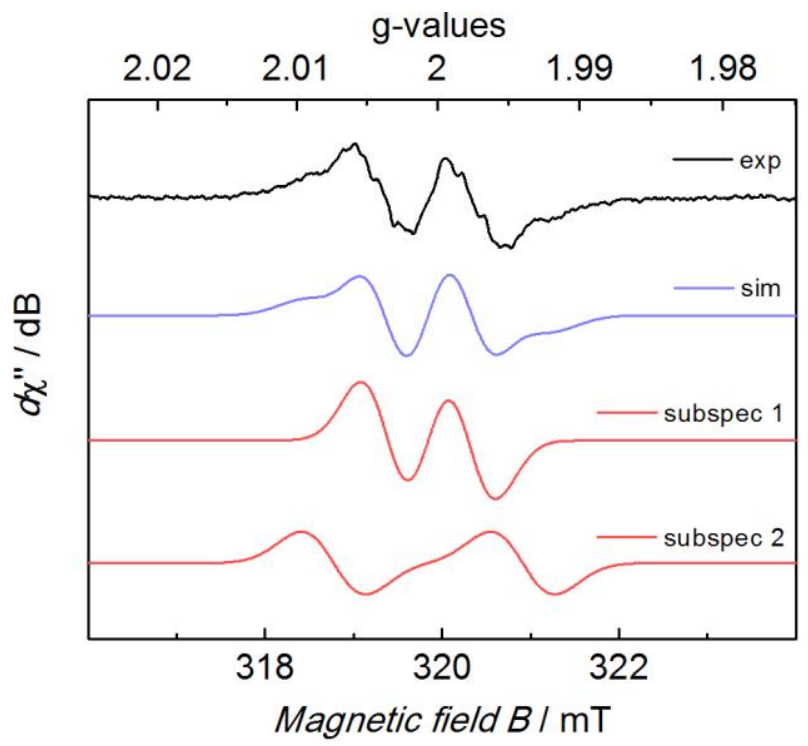

Figure S31. CW X-Band EPR spectrum of the radical anions of $\mathrm{Ph}_{3} \mathrm{PO}$ generated by reduction with an excess of potassium metal, recorded in $0.4 \mathrm{mM}$ THF solution (black trace) at RT and its simulation (blue trace), consisting of two subspectra (red traces). Simulation parameters: Subspectrum 1: weight $=1, S=1 / 2, g_{\text {iso }}=2.00055, A\left({ }^{31} \mathrm{P}\right)=25.9$ $\mathrm{MHz}(0.93 \mathrm{mT})$, and $W_{\text {iso }}=0.35 \mathrm{mT}$; Subspectrum 2: weight $=0.41, S=1 / 2, g_{\text {iso }}=2.00055, A\left({ }^{31} \mathrm{P}\right)=59.9 \mathrm{MHz}(2.14$ $\mathrm{mT}$ ), and $W_{\text {iso }}=0.43 \mathrm{mT}$. Experimental conditions: RT, microwave frequency $8.956 \mathrm{GHz}$, modulation width $2.0 \mathrm{mT}$, microwave power $1 \mathrm{~mW}$, modulation frequency $100 \mathrm{kHz}$, and time constant $0.1 \mathrm{~s}$. 


\section{Computational details}

All structures were fully optimized within two different programs. The B3LYP ${ }^{[20,21]}$ and B3PW91 $1^{[20,22,23]}$ functionals with $6-31 \mathrm{G}(\mathrm{d})^{[24]}$ and def2-TZVP ${ }^{[25]}$ basis sets as well as at the MN12SX ${ }^{[26]} /$ TZVP/Auto level were performed within Gaussian 09 program. ${ }^{[27]}$ BP86, ${ }^{[28]}$ B3LYP, TPSS, ${ }^{[29]}$ and $\mathrm{PBE}^{[22,30]}$ functionals with def2-TZVP and $\mathrm{PBE0}^{[31]} / \mathrm{def} 2-\mathrm{TZVPP}$, PBE0/def2-QZVP in combination with the corresponding Coulomb fitting basis for the resolution of identity were performed with Orca 3.0.2. ${ }^{[32]}$ Grimme's D3 dispersion correction ${ }^{[33]}$ with BJdamping ${ }^{[34]}$ was used in all Orca calculations. The reason for the choice of multiple functionals and basis sets is the extreme sensitivity of the $\mathrm{P}-\mathrm{O}$ bond length towards the method. The results of our calculations for $\mathbf{1}$ together with the results for $\mathrm{Ph}_{3} \mathrm{PO}$ are summarized in Table $\mathrm{S} 1$. The nature of the first excited state $\mathbf{1}-\mathbf{S}_{\mathbf{1}}$ (number of imaginary vibrations $=0$ ) was checked with BP86/def2-TZVPP (Orca 3.0.2). For further analysis (NMR, UV/vis, vide infra) geometries obtained with PBE0/def2-TZVPP and PBE0/def2-QZVP method were used. For the simulation of UV/vis spectra of $\mathbf{1}^{-}$additional calculations were performed with ZINDO/S method (150 roots), ${ }^{[33]}$ as implemented in Orca program. The calculations of the nuclear magnetic shielding tensors were carried out using the gauge-independent atomic orbitals (GIAO) method ${ }^{[36]}$ at the B3LYP/6-31G(d) and B3LYP/6-311+G(d,p) level with Gaussian 09. For calculating chemical shifts phosphoric acid was chosen as an internal standard. To check the validity of the results, chemical shifts were also calculated for $\mathrm{Ph}_{3} \mathrm{PO}$ (Table S3). EPR spectra were calculated at the B3LYP/IGLO-III//PBE0/def2-QZVP level ${ }^{[37]}$ with Gaussian09 and Orca 3.0.2. Anisotropy of the current density (ACID) ${ }^{[9,38]}$ was calculated for $\mathrm{Ph}_{3} \mathrm{PO}$ and 1 with ACID 2.0 software (Fig. S32). To elucidate the considerable shielding of the phosphorus center of $\mathbf{1}$ we carried out population, Mayer's bond order, ${ }^{[39]}$ natural bond orbital (NBO), ${ }^{[40]}$ atoms in molecules (AIM) ${ }^{[41]}$ and electron localization function (ELF) studies. ${ }^{[42]}$ Analysis and visualization of the results were done with the Multiwfn 3.3.7 software. ${ }^{[43]}$

Table S2. Calculated $\mathrm{P}-\mathrm{O}$ bond length $(\AA)$ for $\mathrm{Ph}_{3} \mathrm{PO}$ and $\mathbf{1}$ at different levels of theory.

\begin{tabular}{|l|c|c|}
\hline Method & $\mathrm{Ph}_{3} \mathrm{PO}$ & 1 \\
\hline \multicolumn{3}{|c|}{ Gaussian 09 } \\
\hline B3LYP/6-31G(d) & 1.504 & 1.517 \\
\hline B3LYP/def2-TZVP & & 1.495 \\
\hline
\end{tabular}




\begin{tabular}{|l|c|c|}
\hline B3PW91/6-31G(d) & 1.501 & 1.514 \\
\hline B3PW91/def2-TZVP & & 1.508 \\
\hline PBE0/def2-TZVP & 1.482 & 1.491 \\
\hline MN12SX/TZVP/Auto & 1.505 \\
\hline \multicolumn{2}{|c|}{ Orca 3.0.2 } \\
\hline BP86/def2-TZVP & 1.509 & \\
\hline B3LYP/def2-TZVP & 1.484 & 1.493 \\
\hline B3PW/ def2-TZVP & 1.482 & 1.491 \\
\hline TPSS/def2-TZVP & 1.495 & 1.505 \\
\hline PBE/def2-TZVP & 1.499 & 1.505 \\
\hline PBE0/def2-TZVP & 1.480 & 1.490 \\
\hline PBE0/def2-TZVPP & $\mathbf{1 . 4 8 0}$ & $\mathbf{1 . 4 8 9}$ \\
\hline PBE0/def2-QZVP & $\mathbf{1 . 4 7 8}$ & $\mathbf{1 . 4 8 7}$ \\
\hline \multicolumn{2}{|l}{} \\
\hline Experiment & 1.479 & 1.485 \\
\hline
\end{tabular}

Table S3. Total energy (E / hartree) and dispersion-corrected energy $\left(\mathrm{E}_{\mathrm{D} 3} /\right.$ hartree) of 1, its radical anion 1*- and first excited state 1-S1, $\mathrm{H}_{3} \mathrm{PO}_{4}, \mathrm{Ph}_{3} \mathrm{PO}$ and its radical anion $\mathrm{Ph}_{3} \mathrm{PO}^{-}$calculated at the $\mathrm{PBE}$ /def2-TZVPP and PBE0/def2QZVP levels.

\begin{tabular}{|c|c|c|c|c|}
\hline \multirow{2}{*}{} & \multicolumn{2}{|c|}{ PBE0/def2-TZVPP } & \multicolumn{2}{c|}{ PBE0/def2-QZVP } \\
\cline { 2 - 5 } & $\mathrm{E}$ & $E_{D 3}$ & $\mathrm{E}$ & $E_{D 3}$ \\
\hline $\mathbf{1}$ & -2606.63455 & -2606.80385 & -2606.75382 & -2606.92339 \\
\hline $\mathbf{1}^{-}$ & -2606.65440 & -2606.82411 & -2606.77390 & -2606.94383 \\
\hline $\mathbf{1 - S 1}$ & -2606.62790 & -2606.79756 & - & - \\
\hline $\mathbf{H}_{3} \mathbf{P O}_{\mathbf{4}}$ & -643.90359 & -643.90842 & -643.93336 & -643.93818 \\
\hline $\mathbf{P h}_{3} \mathbf{P O}$ & -1110.81876 & -1110.86661 & -1110.86968 & -1110.91725 \\
\hline $\mathbf{P h}_{3} \mathbf{P O}^{-}$ & -1110.81745 & -1110.86503 & - & - \\
\hline
\end{tabular}


Table S4. GIAO nuclear magnetic shielding tensors $(\sigma / \mathrm{ppm})$ and $\delta\left({ }^{31} \mathrm{P}\right)$ chemical shifts of $\mathbf{1}, \mathrm{Ph}_{3} \mathrm{PO}$ and $\mathrm{H}_{3} \mathrm{PO}_{4}$ as an internal standard, calculated at B3LYP/6-31(d) (abbreviated as DZ) and B3LYP/6-311+(d,p) (abbreviated as TZ) levels.

\begin{tabular}{|c|c|c|c|c|c|c|c|c|c|c|}
\hline & \multicolumn{2}{|c|}{$\sigma_{11}$} & \multicolumn{2}{|c|}{$\sigma_{22}$} & \multicolumn{2}{c|}{$\sigma_{33}$} & \multicolumn{2}{c|}{$\sigma_{\text {iso }}$} & \multicolumn{2}{c|}{$\delta\left({ }^{31} \mathrm{P}\right)$} \\
\hline & DZ & TZ & DZ & TZ & DZ & TZ & DZ & TZ & DZ & TZ \\
\hline $\begin{array}{c}\mathbf{H}_{3} \text { PO }_{4}, \\
\text { PBE0/def2- } \\
\text { TZVPP }\end{array}$ & 313.84 & 224.24 & 325.95 & 234.36 & 516.27 & 450.89 & 385.35 & 303.16 & - & - \\
\hline $\begin{array}{c}\mathbf{H}_{3} \text { PO }_{4}, \\
\text { PBE0/def2- } \\
\text { QZVP }\end{array}$ & 375.16 & 290.68 & 356.78 & 267.93 & 440.50 & 369.14 & 390.83 & 309.25 & & \\
\hline $\begin{array}{c}\text { Ph }{ }_{3} \text { PO } \\
\text { 1, } \\
\text { PBE0/def2- } \\
\text { TZVPP }\end{array}$ & 334.05 & 262.49 & 334.06 & 265.02 & 512.51 & 501.66 & 400.20 & 343.05 & -14.85 & -38.89 \\
\hline $\begin{array}{c}\text { 1, } \\
\text { PBE0/def2- } \\
\text { QZVP }\end{array}$ & 338.31 & 266.22 & 334.15 & 262.66 & 523.66 & 493.20 & 398.67 & 340.69 & -7.84 & -31.33 \\
\hline
\end{tabular}
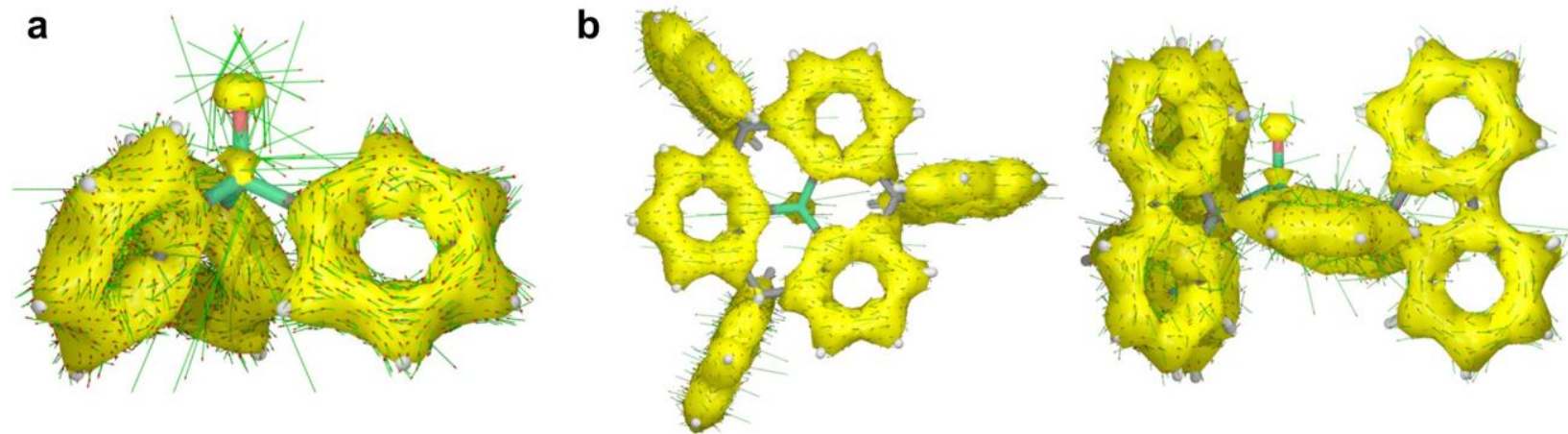

Figure S32. Anisotropy of the current density (ACID) for a) $\mathrm{Ph}_{3} \mathrm{PO}$ and b) 1 (bottom and side view).

\section{Electronic transitions}

UV/vis spectra of 1 were calculated with Gaussian 09 at the TD-B3PW91/def2-TZVP level on the PBE0/def2-TZVPP and PBE0/def2-QZVP optimized geometries, with 30 roots. Geometry optimization of the first excited state 1-S1 at the PBE0/def2-QZVP level appeared to be 
computationally very demanding. Hence we compare here only results obtained at the TDB3PW91/def2-TZVP//PBE0/def2-TZVPP level (Table S5 and S6). Nonetheless, computed excitations for $\mathbf{1}$ are very similar at the TD-B3PW91/def2-TZVP//PBE0/def2-QZVP level. The difference between main peaks in measured and computed spectra are ca. 15-25 nm, which is well within the accuracy of TD-DFT. ${ }^{[4]}$

Table S5. Experimental electronic transition for 1 derived from the UV/vis spectra in $\mathrm{CH}_{2} \mathrm{Cl}_{2}$ and computed excitations (TD-B3PW91/def2-TZVP//PBE0/def2-TZVPP). $\mathrm{H}=$ HOMO; $\mathrm{L}=\mathrm{LUMO} ; f=$ oscillator strength; $\mathrm{Cl}=$ configuration interaction.

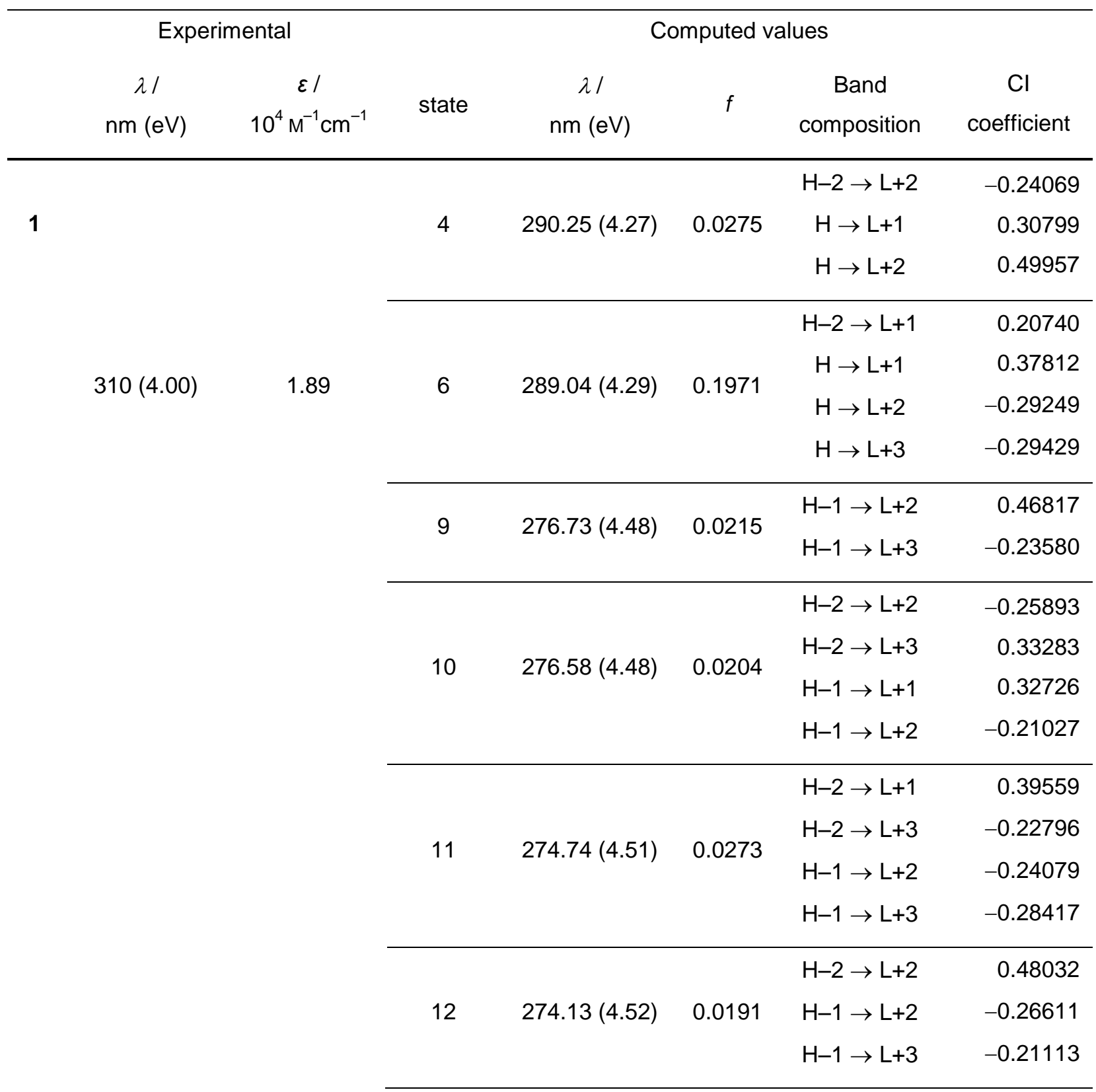




\begin{tabular}{|c|c|c|c|c|c|c|}
\hline & & \multirow{2}{*}{13} & \multirow{2}{*}{$273.67(4.53)$} & \multirow{2}{*}{0.012} & \multirow{2}{*}{$\begin{array}{c}\mathrm{H}-1 \rightarrow \mathrm{L}+3 \\
\mathrm{H} \rightarrow \mathrm{L}+6\end{array}$} & \multirow{2}{*}{$\begin{array}{r}-0.24595 \\
0.41218\end{array}$} \\
\hline & & & & & & \\
\hline & & \multirow{5}{*}{15} & \multirow{5}{*}{$271.56(4.57)$} & \multirow{5}{*}{0.094} & $\mathrm{H}-2 \rightarrow \mathrm{L}+4$ & 0.25814 \\
\hline & & & & & $\mathrm{H}-2 \rightarrow \mathrm{L}+7$ & 0.24356 \\
\hline \multirow[t]{16}{*}{$298(4.16)$} & \multirow[t]{16}{*}{1.68} & & & & $\mathrm{H}-1 \rightarrow \mathrm{L}+3$ & -0.22606 \\
\hline & & & & & $\mathrm{H}-1 \rightarrow \mathrm{L}+6$ & 0.27010 \\
\hline & & & & & $\mathrm{H} \rightarrow \mathrm{L}+8$ & -0.26260 \\
\hline & & \multirow{2}{*}{17} & \multirow{2}{*}{$269.63(4.60)$} & \multirow{2}{*}{0.0133} & $\mathrm{H} \rightarrow \mathrm{L}+4$ & -0.20960 \\
\hline & & & & & $\mathrm{H} \rightarrow \mathrm{L}+5$ & 0.49144 \\
\hline & & \multirow{2}{*}{18} & \multirow{2}{*}{$269.40(4.60)$} & \multirow{2}{*}{0.0258} & $\mathrm{H}-4 \rightarrow \mathrm{L}$ & 0.61818 \\
\hline & & & & & $\mathrm{H}-3 \rightarrow \mathrm{L}$ & -0.19956 \\
\hline & & \multirow{2}{*}{19} & \multirow{2}{*}{$268.62(4.62)$} & \multirow{2}{*}{0.0204} & $\mathrm{H}-1 \rightarrow \mathrm{L}+4$ & 0.33502 \\
\hline & & & & & $\mathrm{H}-1 \rightarrow \mathrm{L}+7$ & -0.29912 \\
\hline & & 20 & $268.20(4.62)$ & 0.0193 & $\mathrm{H}-5 \rightarrow \mathrm{L}$ & 0.62115 \\
\hline & & 25 & $261.36(4.74)$ & 0.1128 & $\mathrm{H}-6 \rightarrow \mathrm{L}$ & 0.63397 \\
\hline & & 26 & $259.81(4.77)$ & 0.1209 & $\mathrm{H}-7 \rightarrow \mathrm{L}$ & 0.63298 \\
\hline & & \multirow{2}{*}{27} & \multirow{2}{*}{$256.37(4.84)$} & \multirow{2}{*}{0.0152} & $\mathrm{H}-14 \rightarrow \mathrm{L}$ & 0.21073 \\
\hline & & & & & $\mathrm{H}-9 \rightarrow \mathrm{L}$ & 0.62138 \\
\hline & & \multirow{2}{*}{30} & \multirow{2}{*}{$254.33(4.87)$} & \multirow{2}{*}{0.0359} & $\mathrm{H}-3 \rightarrow \mathrm{L}+3$ & 0.23754 \\
\hline & & & & & $\mathrm{H} \rightarrow \mathrm{L}+7$ & 0.24793 \\
\hline
\end{tabular}

Table S6. Experimental electronic transition derived from the emission spectra in $\mathrm{CH}_{2} \mathrm{Cl}_{2}$ and computed emissions for the neutral first excited state 1-S1 (TD-B3PW91/def2-TZVP//PBE0/def2-TZVPP). H = HOMO; L = LUMO; $f=$ oscillator strength; $\mathrm{Cl}=$ configuration interaction.

\section{Experimental}

$\lambda / \quad \varepsilon /$

$\mathrm{nm}(\mathrm{eV})$

\begin{abstract}
${ }^{-1} \mathrm{~cm}^{-1}$
\end{abstract}
Computed values $^{\lfloor\mathrm{a}\rfloor}$

state

$\lambda /$

$\mathrm{nm}(\mathrm{eV})$
Band

composition coefficient

\begin{tabular}{lrrrrrr}
\hline 1-S1 $324(3.83)$ & 4 & $304.2(4.08)$ & 0.1461 & $\mathrm{H} \rightarrow \mathrm{L}+1$ & 0.67267 \\
\cline { 2 - 6 } & 6 & $296.14(4.19)$ & 0.0189 & $\mathrm{H} \rightarrow \mathrm{L}+2$ & -0.41290 \\
& & & & $\mathrm{H} \rightarrow \mathrm{L}+3$ & 0.52291
\end{tabular}




\begin{tabular}{|c|c|c|c|c|}
\hline \multirow{4}{*}{7} & \multirow{4}{*}{$291.28(4.26)$} & \multirow{4}{*}{0.0097} & $\mathrm{H} \rightarrow \mathrm{L}+4$ & -0.26296 \\
\hline & & & $\mathrm{H} \rightarrow \mathrm{L}+5$ & 0.43561 \\
\hline & & & $\mathrm{H} \rightarrow \mathrm{L}+6$ & -0.25248 \\
\hline & & & $\mathrm{H} \rightarrow \mathrm{L}+7$ & -0.24341 \\
\hline \multirow{3}{*}{9} & \multirow{3}{*}{286.08 (4.33) } & \multirow{3}{*}{0.1821} & $\mathrm{H}-2 \rightarrow \mathrm{L}+2$ & 0.23599 \\
\hline & & & $\mathrm{H}-1 \rightarrow \mathrm{L}+2$ & -0.31608 \\
\hline & & & $\mathrm{H}-1 \rightarrow \mathrm{L}+3$ & 0.41790 \\
\hline \multirow{2}{*}{12} & \multirow{2}{*}{$281.54(4.40)$} & \multirow{2}{*}{0.0092} & $\mathrm{H}-4 \rightarrow \mathrm{L}$ & 0.58874 \\
\hline & & & $\mathrm{H}-1 \rightarrow \mathrm{L}+1$ & -0.24738 \\
\hline \multirow{2}{*}{13} & \multirow{2}{*}{$281.45(4.41)$} & \multirow{2}{*}{0.0082} & $\mathrm{H}-4 \rightarrow \mathrm{L}$ & 0.30897 \\
\hline & & & $\mathrm{H}-1 \rightarrow \mathrm{L}+1$ & 0.51551 \\
\hline 14 & $281.08(4.41)$ & 0.0059 & $\mathrm{H}-5 \rightarrow \mathrm{L}$ & 0.61788 \\
\hline \multirow{4}{*}{15} & \multirow{4}{*}{$279.75(4.43)$} & \multirow{4}{*}{0.0289} & $\mathrm{H}-12 \rightarrow \mathrm{L}+1$ & -0.28744 \\
\hline & & & $\mathrm{H}-1 \rightarrow \mathrm{L}+5$ & 0.24756 \\
\hline & & & $\mathrm{H} \rightarrow \mathrm{L}+6$ & 0.36624 \\
\hline & & & $\mathrm{H} \rightarrow \mathrm{L}+10$ & -0.20870 \\
\hline \multirow{2}{*}{17} & \multirow{2}{*}{$277.08(4.47)$} & \multirow{2}{*}{0.0117} & $\mathrm{H}-2 \rightarrow \mathrm{L}+2$ & 0.41474 \\
\hline & & & $\mathrm{H}-1 \rightarrow \mathrm{L}+2$ & 0.38948 \\
\hline \multirow{4}{*}{18} & \multirow{4}{*}{$275.74(4.50)$} & \multirow{4}{*}{0.0185} & $\mathrm{H}-2 \rightarrow \mathrm{L}+1$ & 0.21623 \\
\hline & & & $\mathrm{H}-2 \rightarrow \mathrm{L}+2$ & -0.23152 \\
\hline & & & $\mathrm{H}-2 \rightarrow \mathrm{L}+3$ & 0.49560 \\
\hline & & & $\mathrm{H}-1 \rightarrow \mathrm{L}+3$ & -0.22269 \\
\hline \multirow{3}{*}{20} & \multirow{3}{*}{$273.28(4.54)$} & \multirow{3}{*}{0.0832} & $\mathrm{H}-2 \rightarrow \mathrm{L}+2$ & 0.24915 \\
\hline & & & $\mathrm{H}-2 \rightarrow \mathrm{L}+3$ & 0.29674 \\
\hline & & & $\mathrm{H}-2 \rightarrow \mathrm{L}+4$ & 0.34462 \\
\hline 21 & $272.78(4.55)$ & 0.164 & $\mathrm{H}-6 \rightarrow \mathrm{L}$ & 0.60035 \\
\hline 22 & $272.16(4.56)$ & 0.1589 & $\mathrm{H}-7 \rightarrow \mathrm{L}$ & 0.60119 \\
\hline \multirow{4}{*}{25} & \multirow{4}{*}{$266.4(4.65)$} & \multirow{4}{*}{0.0124} & $\mathrm{H}-10 \rightarrow \mathrm{L}$ & 0.24590 \\
\hline & & & $\mathrm{H}-9 \rightarrow \mathrm{L}$ & -0.20668 \\
\hline & & & $\mathrm{H}-1 \rightarrow \mathrm{L}+4$ & 0.30949 \\
\hline & & & $\mathrm{H}-1 \rightarrow \mathrm{L}+7$ & 0.30309 \\
\hline
\end{tabular}




\begin{tabular}{|c|c|c|c|c|}
\hline & & & $\mathrm{H} \rightarrow \mathrm{L}+10$ & 0.21471 \\
\hline \multirow{4}{*}{27} & \multirow{4}{*}{265.95 (4.66) } & \multirow{4}{*}{0.0126} & $\mathrm{H}-9 \rightarrow \mathrm{L}$ & 0.29239 \\
\hline & & & $\mathrm{H}-1 \rightarrow \mathrm{L}+5$ & 0.29269 \\
\hline & & & $\mathrm{H}-1 \rightarrow \mathrm{L}+6$ & 0.29797 \\
\hline & & & $\mathrm{H}-1 \rightarrow \mathrm{L}+7$ & 0.21041 \\
\hline \multirow{3}{*}{29} & \multirow{3}{*}{264.44 (4.69) } & \multirow{3}{*}{0.0127} & $\mathrm{H}-2 \rightarrow \mathrm{L}+4$ & -0.27677 \\
\hline & & & $\mathrm{H}-2 \rightarrow \mathrm{L}+5$ & 0.40859 \\
\hline & & & $\mathrm{H}-2 \rightarrow \mathrm{L}+7$ & -0.25695 \\
\hline \multirow{4}{*}{30} & \multirow{4}{*}{$263.77(4.70)$} & \multirow{4}{*}{0.0155} & $\mathrm{H}-2 \rightarrow \mathrm{L}+4$ & 0.28549 \\
\hline & & & $\mathrm{H}-2 \rightarrow \mathrm{L}+5$ & 0.28489 \\
\hline & & & $\mathrm{H}-2 \rightarrow \mathrm{L}+6$ & 0.24307 \\
\hline & & & $\mathrm{H}-2 \rightarrow \mathrm{L}+7$ & 0.29058 \\
\hline
\end{tabular}

In the case of $\mathbf{1}^{-}$, TD-DFT calculations completely fail to reproduce the UV/vis spectra. This is not entirely surprising as it was shown before that TD-DFT has difficulties describing open-shell systems and processes that involve double excitations. ${ }^{[45]}$ Hence, as an alternative for $\mathbf{1}^{--}$the ZINDO/S approach with 150 roots was used (Fig. S33, blue curve). While the peak positions are still off by $40-60 \mathrm{~nm}$, it can be anticipated that the band around $485 \mathrm{~nm}$ belongs to multiple excitations from SOMO to LUMO and higher lying LUMO+n and the band around $378 \mathrm{~nm}$ corresponds to multiple HOMO-n $\rightarrow$ LUMO+n excitations within window of 12 active orbitals (i.e., HOMO-5 to LUMO+5). 


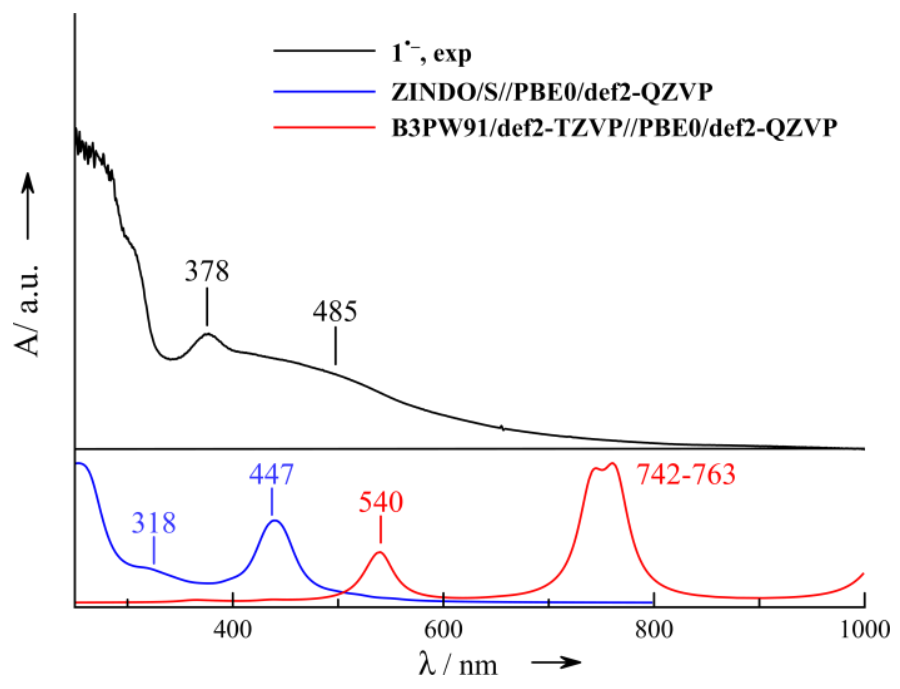

Figure S33. UV/vis absorption (black) of radical anion 1-- obtained by treatment of 1 with potassium (exc.) in THF at $\mathrm{RT}$ in the presence of [2.2.2]cryptand (1.1 equiv.) for $14 \mathrm{~h}$ and ZINDO/S calculations of 1- (blue). TD-DFT calculations fail to reproduce experimentally observed UV/vis spectra (red). 


\section{NBO/NLMO Analysis}

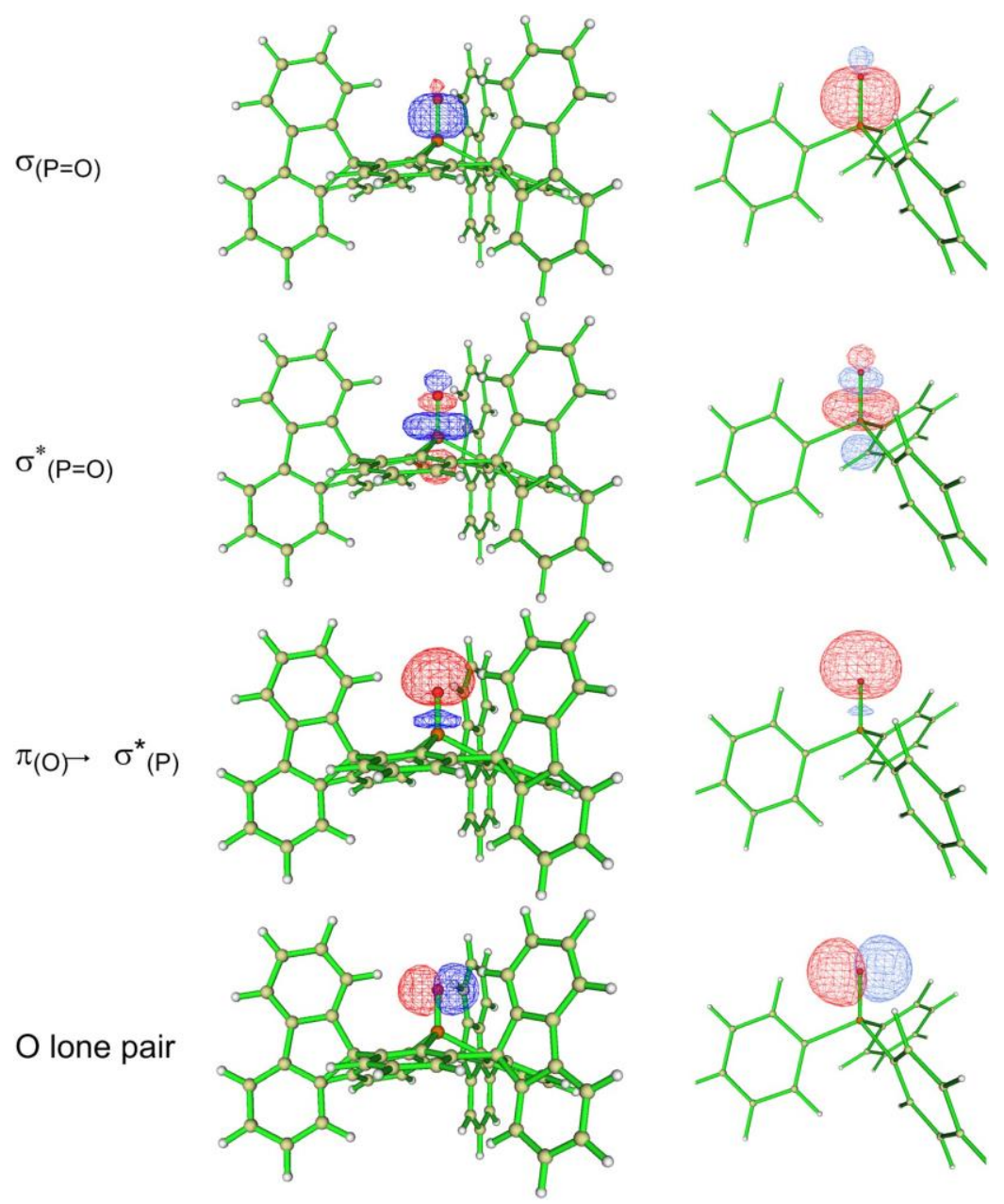

Figure S34. NBO/NLMO properties of 1 and $\mathrm{Ph}_{3} \mathrm{PO} . \sigma(\mathrm{P}-\mathrm{O})$ bonding orbital, $\sigma^{*}(\mathrm{P}-\mathrm{O})$ antibonding orbital, one of the two oxygen lone pair orbitals that are not participating in hyperconjugation with orbitals of phosphorus atom, oxygen lone pair orbital that is participating in hyperconjugation with orbitals of $\mathrm{P}\left(\pi(\mathrm{O}) \rightarrow \sigma^{*}(\mathrm{P})\right)$. 


\section{AIM/ELF Results}

On the basis of the AIM analysis it was found, that there is a slight change in charge distribution on the oxygen atom of $1(-0.36 \mathrm{e})$ compared to $-0.41 \mathrm{e}$ in $\mathrm{Ph}_{3} \mathrm{PO}$, whereas charges on the phosphorus atom of $\mathbf{1}(0.33 \mathrm{e})$ remain virtually the same as for $\mathrm{Ph}_{3} \mathrm{PO}(0.34 \mathrm{e})$.

a)
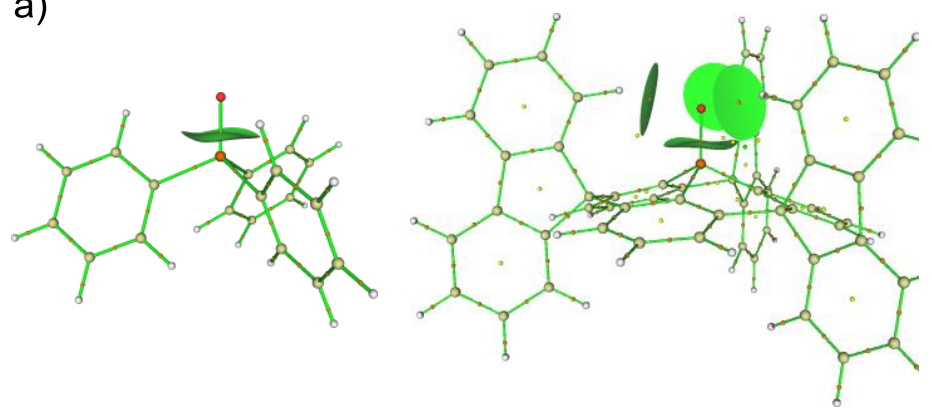

b)

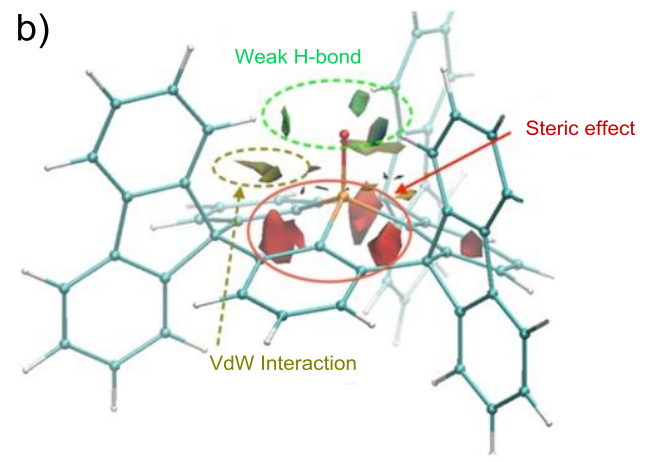

Figure S35. AIM/ELF analysis of 1. a) AIM analysis of $\mathrm{Ph}_{3} \mathrm{PO}$ (left) and 1 (right) with bond critical points and selected interbasin. b) Reduced density gradient analysis of $\mathbf{1}$; for clarity only interactions in vicinity of the $\mathrm{P}-\mathrm{O}$ moiety are plotted.

\section{Mayer's Bond Order}

The decrease of Mayer's bond order (PBE0/def2-TZVPP) from 1.59 in $\mathbf{1}$ to 1.48 in $\mathbf{1}^{{ }^{-}}$is in good agreement with the calculated elongation of the $\mathrm{P}-\mathrm{O}$ bond length by $0.014 \AA$. This effect is less pronounced for the reduction of $\mathrm{Ph}_{3} \mathrm{PO}$, showing a bond order of 2.05, to $\mathrm{Ph}_{3} \mathrm{PO}^{--}$with 2.01, which is accompanied by an increase of the $\mathrm{P}-\mathrm{O}$ bond length of $0.012 \AA$. 


\section{Orbitals}

1

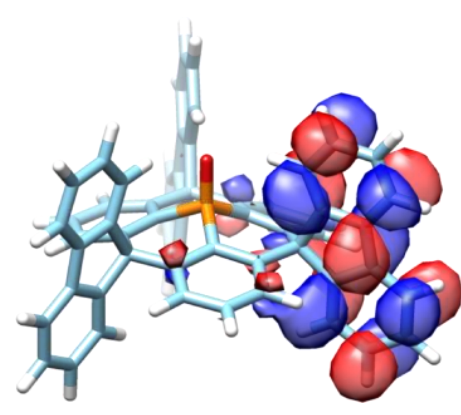

LUMO+2

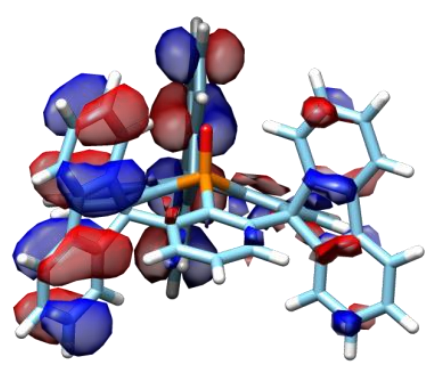

HOMO-2

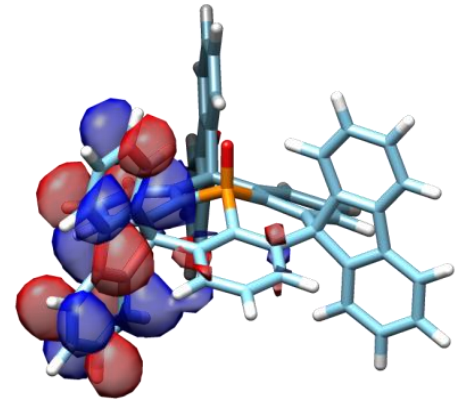

LUMO+1

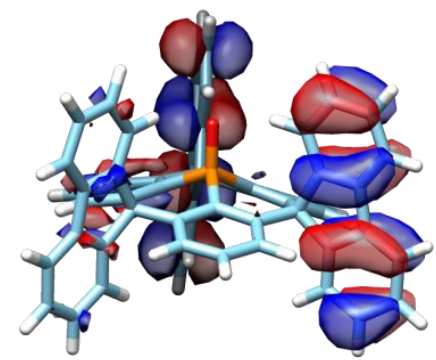

HOMO-1

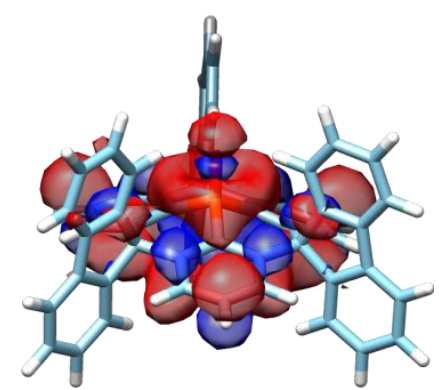

LUMO

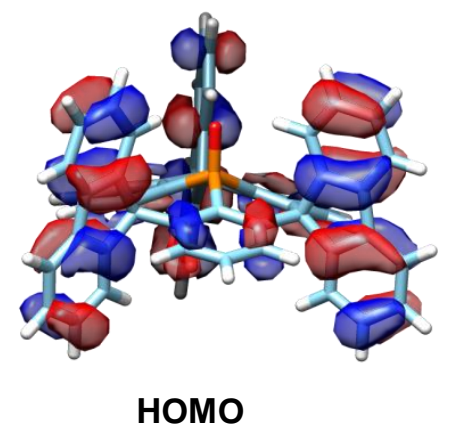

$1^{-}$

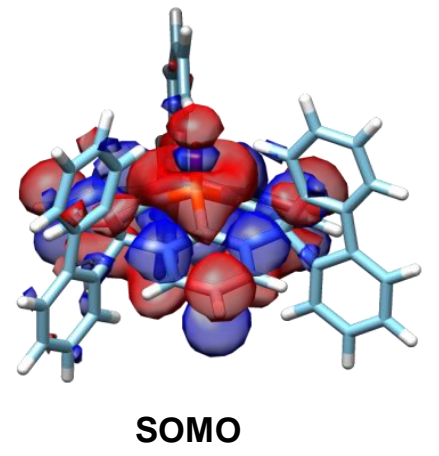




\section{Archives}

\section{Compound 1 (PBE0/def2-QZVP)}

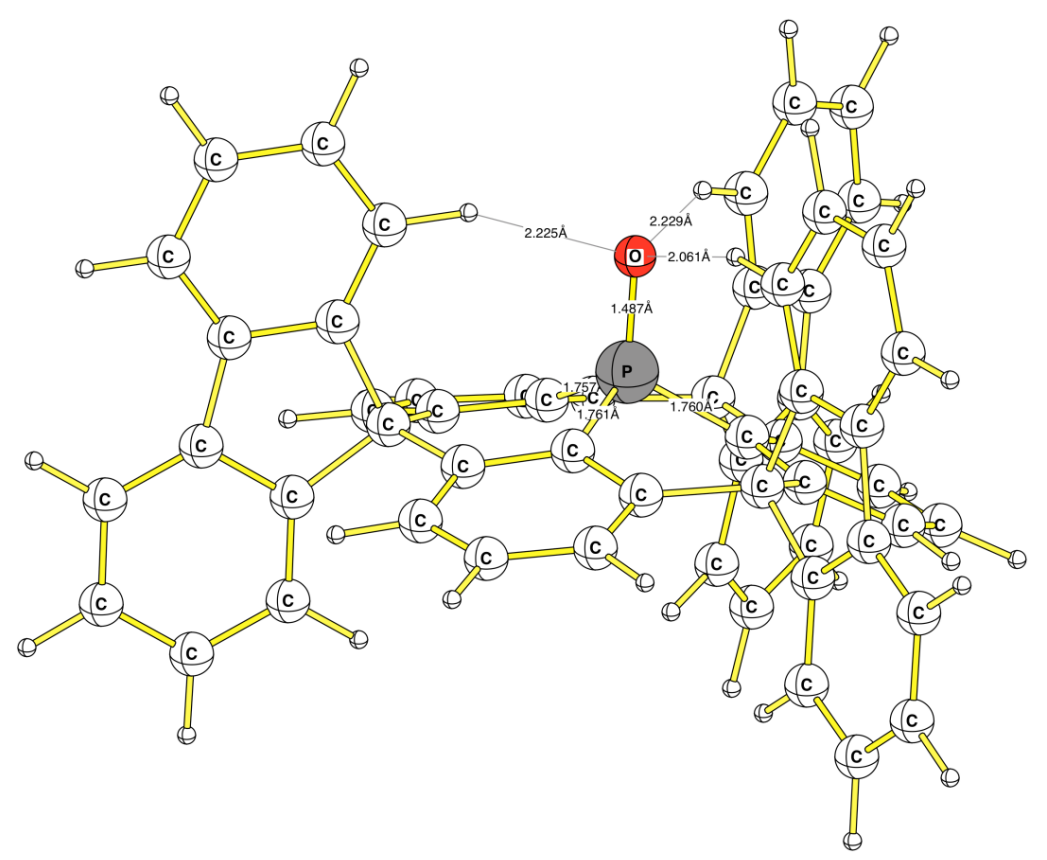

92XYZ file generated by orca_plot on BaseName=SPO-neut_qz

$\begin{array}{lrrr}\mathrm{C} & 1.470118 & -0.601136 & -0.144426 \\ \mathrm{C} & 1.523893 & -1.963508 & -0.463310 \\ \mathrm{C} & 2.709686 & -2.452028 & -0.993063 \\ \mathrm{H} & 2.799614 & -3.497634 & -1.253112 \\ \mathrm{C} & 3.772538 & -1.595458 & -1.221929 \\ \mathrm{H} & 4.691083 & -1.990606 & -1.637698 \\ \mathrm{C} & 3.670253 & -0.237650 & -0.977611 \\ \mathrm{H} & 4.498039 & 0.411136 & -1.226377 \\ \mathrm{C} & 2.505123 & 0.290627 & -0.434472 \\ \mathrm{C} & -1.266276 & -0.889103 & -0.101144 \\ \mathrm{C} & -2.478050 & -0.240743 & -0.356506 \\ \mathrm{C} & -3.531666 & -1.006912 & -0.841572 \\ \mathrm{H} & -4.486921 & -0.546859 & -1.052456 \\ \mathrm{C} & -3.360086 & -2.360745 & -1.069857 \\ \mathrm{H} & -4.194403 & -2.948491 & -1.431703 \\ \mathrm{C} & -2.128107 & -2.967462 & -0.891171 \\ \mathrm{H} & -2.007366 & -4.012370 & -1.140651 \\ \mathrm{C} & -1.048244 & -2.234067 & -0.420100 \\ \mathrm{C} & -0.149711 & 1.638033 & -0.008049 \\ \mathrm{C} & 0.999660 & 2.405569 & -0.198379 \\ \mathrm{C} & 0.834875 & 3.763637 & -0.431533 \\ \mathrm{H} & 1.701395 & 4.397332 & -0.563675 \\ \mathrm{C} & -0.437285 & 4.303827 & -0.516155\end{array}$




\begin{tabular}{|c|c|c|c|}
\hline & -0.550316 & 4247 & \\
\hline & -1.566303 & 3.505682 & 3349 \\
\hline & -2.546964 & 942774 & -0.555375 \\
\hline & -1.440613 & 144956 & -0.173061 \\
\hline & 0.327596 & 904137 & 25839 \\
\hline & 0.419499 & .087080 & -1.209553 \\
\hline & 0.415230 & .069676 & 90775 \\
\hline & 0.369858 & .131188 & -3.13010 \\
\hline & 0.470339 & 6045 & $15 t$ \\
\hline & 0.467468 & 0845 & \\
\hline & & & \\
\hline & & 21 & \\
\hline & & -6. & \\
\hline & & & \\
\hline & 0.485087 & 3083 & \\
\hline & 609 & & \\
\hline & & & \\
\hline & & & \\
\hline & & & \\
\hline & & & \\
\hline & & -3 . & \\
\hline & 76 & -3 & \\
\hline & & $-3 .($ & \\
\hline & & & \\
\hline & & & \\
\hline & & & \\
\hline & & & \\
\hline & & & \\
\hline & 2.2 & & \\
\hline & 4.0 & & -3 \\
\hline & 604 & & \\
\hline & & & \\
\hline & & & \\
\hline & & & \\
\hline & & & \\
\hline & & & \\
\hline & & & \\
\hline & 10 & & \\
\hline & & & \\
\hline & & & \\
\hline & & & \\
\hline & & & \\
\hline & & & \\
\hline & & & \\
\hline & & & \\
\hline & 0 & & \\
\hline & & & \\
\hline & -3.7 & & -1 \\
\hline & -3.6 & & 503 \\
\hline & -2.7 & & 474 \\
\hline & & & \\
\hline & & & \\
\hline & & & \\
\hline & & & \\
\hline & & & -1.11256 \\
\hline & -6.957125 & 2.787786 & -0.60466 \\
\hline & -4.927832 & 2.094258 & -0.401 \\
\hline
\end{tabular}




$\begin{array}{llll}\mathrm{C} & -4.737513 & 1.858281 & 1.026177 \\ \mathrm{C} & -5.614316 & 1.990397 & 2.091386 \\ \mathrm{H} & -6.632542 & 2.324911 & 1.934168 \\ \mathrm{C} & -5.162181 & 1.694304 & 3.369561 \\ \mathrm{H} & -5.832940 & 1.797148 & 4.213205 \\ \mathrm{C} & -3.853079 & 1.275681 & 3.576217 \\ \mathrm{H} & -3.513140 & 1.048654 & 4.578663 \\ \mathrm{C} & -2.971325 & 1.133368 & 2.511631 \\ \mathrm{H} & -1.955286 & 0.793334 & 2.674965 \\ \mathrm{C} & -3.427266 & 1.415622 & 1.239530 \\ \mathrm{O} & 0.058606 & 0.007549 & 2.146211 \\ \mathrm{P} & 0.033829 & 0.022865 & 0.659257\end{array}$

\section{Radical anion 1- $($ PBE0/def2-QZVP)}

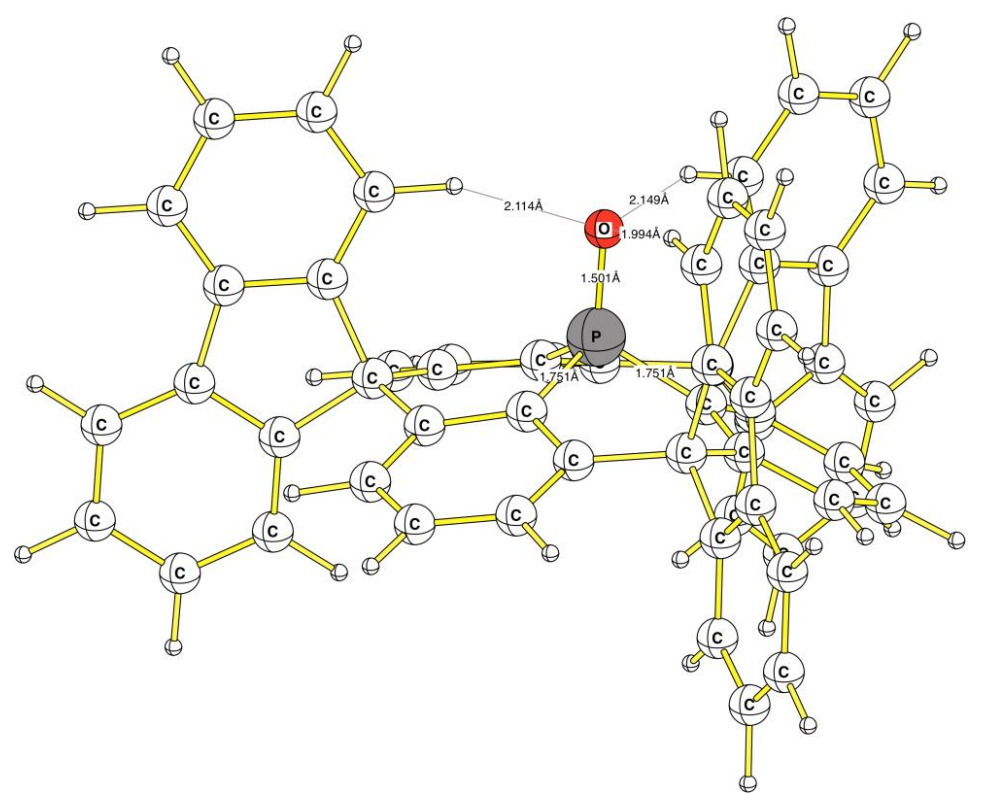

92 XYZ file generated by orca_plot on BaseName=SPO-ra_qz

$\begin{array}{lrrr}\mathrm{C} & 1.444363 & -0.584941 & -0.152479 \\ \mathrm{C} & 1.519252 & -1.956780 & -0.503010 \\ \mathrm{C} & 2.684455 & -2.423592 & -1.085655 \\ \mathrm{H} & 2.771122 & -3.468039 & -1.354777 \\ \mathrm{C} & 3.742296 & -1.567296 & -1.355151 \\ \mathrm{H} & 4.650501 & -1.953991 & -1.800125 \\ \mathrm{C} & 3.620853 & -0.205698 & -1.096178 \\ \mathrm{H} & 4.430305 & 0.454701 & -1.373848 \\ \mathrm{C} & 2.484213 & 0.305229 & -0.496157 \\ \mathrm{C} & -1.245321 & -0.875605 & -0.122536\end{array}$




\begin{tabular}{|c|c|c|c|}
\hline$y$ & -2.465141 & -0.232287 & -0.439914 \\
\hline & -3.475670 & -0.973370 & -1.025835 \\
\hline $\mathrm{H}$ & -4.417351 & -0.502704 & -1.273106 \\
\hline $\mathrm{C}$ & -3.301402 & -2.324221 & -1.310156 \\
\hline $\mathrm{H}$ & -4.112495 & -2.896173 & -1.742745 \\
\hline $\mathrm{C}$ & -2.070650 & -2.926862 & -1.077369 \\
\hline $\mathrm{H}$ & -1.931413 & -3.960041 & -1.365903 \\
\hline $\mathrm{C}$ & -1.028590 & -2.226096 & -0.497190 \\
\hline $\mathrm{C}$ & -0.158852 & 1.623467 & -0.011361 \\
\hline $\mathrm{C}$ & 0.984049 & 2.407445 & -0.253132 \\
\hline $\mathrm{C}$ & 0.815430 & 3.746769 & -0.559894 \\
\hline $\mathrm{H}$ & 1.684296 & 4.370700 & -0.723393 \\
\hline $\mathrm{C}$ & -0.455137 & 4.294555 & -0.676655 \\
\hline $\mathrm{H}$ & -0.569870 & 5.345383 & -0.910350 \\
\hline $\mathrm{C}$ & -1.576103 & 3.483314 & -0.553708 \\
\hline $\mathrm{H}$ & -2.559036 & 3.906416 & -0.715257 \\
\hline C & -1.450570 & 2.141847 & -0.230822 \\
\hline $\mathrm{C}$ & 0.335890 & -2.909560 & -0.268032 \\
\hline $\mathrm{C}$ & 0.444327 & -4.125632 & -1.173005 \\
\hline $\mathrm{C}$ & 0.475746 & -4.154757 & -2.554172 \\
\hline $\mathrm{H}$ & 0.453851 & -3.229228 & -3.116201 \\
\hline $\mathrm{C}$ & 0.538705 & -5.380229 & -3.203400 \\
\hline $\mathrm{H}$ & 0.567333 & -5.416781 & -4.285305 \\
\hline C & 0.565533 & -6.565892 & -2.475274 \\
\hline $\mathrm{H}$ & 0.608064 & -7.514100 & -2.998145 \\
\hline $\mathrm{C}$ & 0.540262 & -6.540087 & -1.088577 \\
\hline $\mathrm{H}$ & 0.561070 & -7.463196 & -0.521461 \\
\hline $\mathrm{C}$ & 0.483025 & -5.312206 & -0.440429 \\
\hline 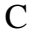 & 0.444744 & -4.979424 & 0.979431 \\
\hline 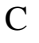 & 0.464953 & -5.800823 & 2.097459 \\
\hline $\mathrm{H}$ & 0.513533 & -6.878293 & 1.990056 \\
\hline $\mathrm{C}$ & 0.427291 & -5.220858 & 3.356354 \\
\hline $\mathrm{H}$ & 0.439886 & -5.848634 & 4.239467 \\
\hline$C$ & 0.378750 & -3.838292 & 3.485607 \\
\hline $\mathrm{H}$ & 0.353744 & -3.387132 & 4.470292 \\
\hline 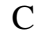 & 0.358436 & -3.012881 & 2.368154 \\
\hline $\mathrm{H}$ & 0.314056 & -1.937124 & 2.490581 \\
\hline $\mathrm{C}$ & 0.381469 & -3.586465 & 1.112124 \\
\hline$C$ & 2.395781 & 1.817773 & -0.186712 \\
\hline $\mathrm{C}$ & 3.323047 & 2.549313 & -1.140313 \\
\hline $\mathrm{C}$ & 3.170838 & 2.727465 & -2.500032 \\
\hline $\mathrm{H}$ & 2.287153 & 2.350986 & -3.000686 \\
\hline $\mathrm{C}$ & 4.158807 & 3.401653 & -3.205310 \\
\hline $\mathrm{H}$ & 4.040560 & 3.569937 & -4.268735 \\
\hline $\mathrm{C}$ & 5.297742 & 3.866269 & -2.554124 \\
\hline $\mathrm{H}$ & 6.065932 & 4.378808 & -3.120301 \\
\hline$C$ & 5.451760 & 3.689174 & -1.186796 \\
\hline $\mathrm{H}$ & 6.334335 & 4.063756 & -0.681559 \\
\hline 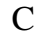 & 4.452909 & 3.033111 & -0.479119 \\
\hline $\mathrm{C}$ & 4.315332 & 2.736486 & 0.942489 \\
\hline C & 5.159687 & 3.014606 & 2.005997 \\
\hline $\mathrm{H}$ & 6.116332 & 3.496577 & 1.842978 \\
\hline C & 4.750574 & 2.678360 & 3.288753 \\
\hline $\mathrm{H}$ & 5.392785 & 2.897403 & 4.133605 \\
\hline$c$ & 3.510117 & 2.086743 & 3.497521 \\
\hline 1 & 3.191238 & 1.841143 & 4.503388 \\
\hline $\mathrm{C}$ & 2.665607 & 1.794170 & 2.432751 \\
\hline
\end{tabular}




$\begin{array}{lrrr}\mathrm{H} & 1.704691 & 1.321083 & 2.598034 \\ \mathrm{C} & 3.087931 & 2.095355 & 1.152333 \\ \mathrm{C} & -2.701458 & 1.260024 & -0.120720 \\ \mathrm{C} & -3.795524 & 1.788892 & -1.033971 \\ \mathrm{C} & -3.736695 & 1.999567 & -2.397960 \\ \mathrm{H} & -2.818690 & 1.807389 & -2.939352 \\ \mathrm{C} & -4.866053 & 2.467085 & -3.056326 \\ \mathrm{H} & -4.828805 & 2.653188 & -4.122748 \\ \mathrm{C} & -6.042955 & 2.710726 & -2.355755 \\ \mathrm{H} & -6.918935 & 3.063077 & -2.887165 \\ \mathrm{C} & -6.099352 & 2.518251 & -0.982703 \\ \mathrm{H} & -7.010516 & 2.731057 & -0.436069 \\ \mathrm{C} & -4.965070 & 2.060477 & -0.323911 \\ \mathrm{C} & -4.717288 & 1.801556 & 1.089276 \\ \mathrm{C} & -5.557288 & 1.923068 & 2.185293 \\ \mathrm{H} & -6.584877 & 2.245503 & 2.061729 \\ \mathrm{C} & -5.054916 & 1.641177 & 3.447802 \\ \mathrm{H} & -5.695676 & 1.735099 & 4.316419 \\ \mathrm{C} & -3.729038 & 1.253434 & 3.601820 \\ \mathrm{H} & -3.343127 & 1.040009 & 4.591260 \\ \mathrm{C} & -2.883146 & 1.127574 & 2.505805 \\ \mathrm{H} & -1.851839 & 0.816529 & 2.632953 \\ \mathrm{C} & -3.389225 & 1.384110 & 1.245533 \\ \mathrm{O} & 0.050349 & 0.014568 & 2.178933 \\ \mathrm{P} & 0.027230 & 0.022249 & 0.678178\end{array}$

\section{Excited state of 1-S1 (PBE0/def2-TZVPP)}

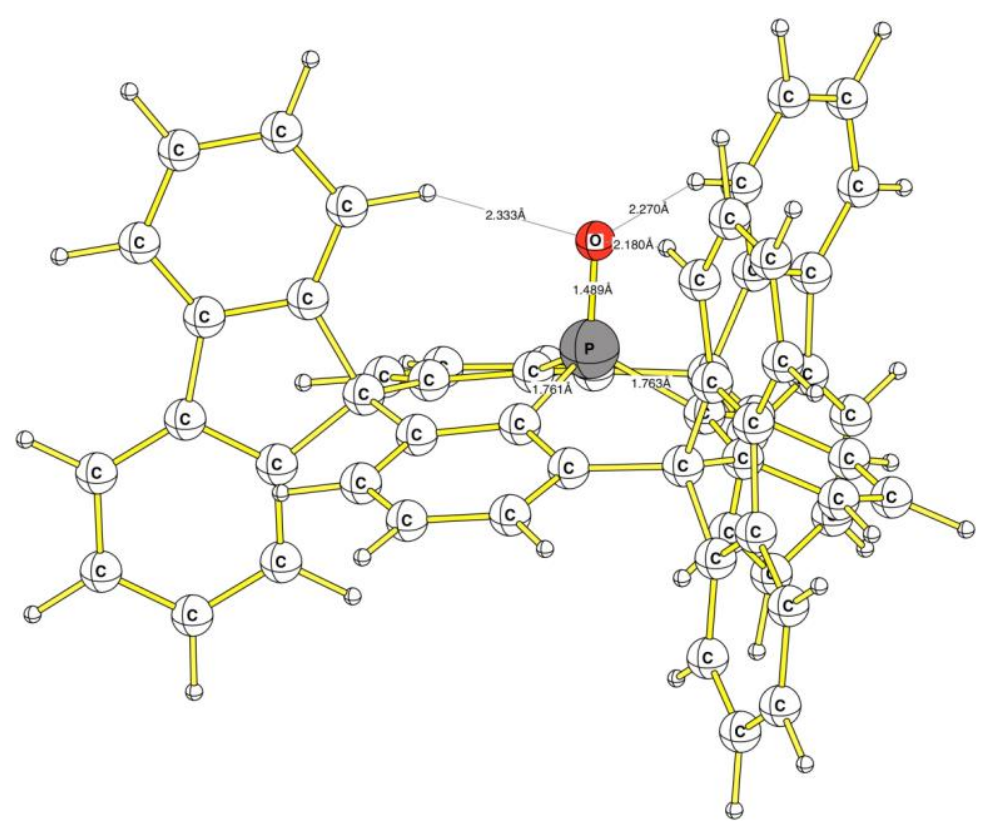

92 Coordinates from ORCA-job SPO-excited_qz 


$\begin{array}{cccc}\mathrm{C} & 1.486180 & -0.626938 & -0.085275 \\ \mathrm{C} & 1.523308 & -1.991809 & -0.396621 \\ \mathrm{C} & 2.711754 & -2.503356 & -0.900662 \\ \mathrm{H} & 2.789843 & -3.554654 & -1.144527 \\ \mathrm{C} & 3.791935 & -1.665203 & -1.123800 \\ \mathrm{H} & 4.711022 & -2.080036 & -1.520139 \\ \mathrm{C} & 3.702051 & -0.302039 & -0.900973 \\ \mathrm{H} & 4.540222 & 0.337234 & -1.144926 \\ \mathrm{C} & 2.536047 & 0.247087 & -0.380370 \\ \mathrm{C} & -1.252810 & -0.876713 & -0.031479 \\ \mathrm{C} & -2.463861 & -0.218749 & -0.261381 \\ \mathrm{C} & -3.541624 & -0.984222 & -0.692715 \\ \mathrm{H} & -4.500492 & -0.519152 & -0.877684 \\ \mathrm{C} & -3.393966 & -2.344136 & -0.901058 \\ \mathrm{H} & -4.247020 & -2.928570 & -1.223980 \\ \mathrm{C} & -2.163151 & -2.961364 & -0.752588 \\ \mathrm{H} & -2.059139 & -4.013686 & -0.981732 \\ \mathrm{C} & -1.059995 & -2.228146 & -0.337085 \\ \mathrm{C} & -0.103602 & 1.633955 & 0.055113 \\ \mathrm{C} & 1.053611 & 2.384238 & -0.159351 \\ \mathrm{C} & 0.903896 & 3.743105 & -0.404177 \\ \mathrm{H} & 1.776366 & 4.364609 & -0.558102 \\ \mathrm{C} & -0.361131 & 4.302643 & -0.475458 \\ \mathrm{H} & -0.461141 & 5.364328 & -0.666033 \\ \mathrm{C} & -1.499243 & 3.518796 & -0.367796 \\ \mathrm{H} & -2.476726 & 3.965873 & -0.498142 \\ \mathrm{C} & -1.387964 & 2.157986 & -0.111254 \\ \mathrm{C} & 0.308645 & -2.916230 & -0.222011 \\ \mathrm{C} & 0.374539 & -4.052527 & -1.235662 \\ \mathrm{C} & 0.338249 & -3.969293 & -2.614765 \\ \mathrm{H} & 0.272873 & -3.006865 & -3.109329 \\ \mathrm{C} & 0.379221 & -5.142677 & -3.359028 \\ \mathrm{H} & 0.347475 & -5.096341 & -4.440688 \\ \mathrm{C} & 0.455798 & -6.379248 & -2.725353 \\ \mathrm{H} & 0.483748 & -7.283870 & -3.320721 \\ \mathrm{C} & 0.492959 & -6.463475 & -1.341630 \\ \mathrm{H} & 0.550126 & -7.428586 & -0.853082 \\ \mathrm{H} & 3.885987 & 3.334335 & -4.377423 \\ \mathrm{C} & 5.119571 & 3.889019 & -2.708662 \\ \mathrm{C} & 0.452132 & -5.291016 & -0.597298 \\ \mathrm{C} & 0.453369 & -5.073206 & 0.845840 \\ \mathrm{C} & 0.495376 & -5.979426 & 1.895206 \\ \mathrm{H} & 0.549835 & -7.045069 & 1.705711 \\ \mathrm{C} & 0.463319 & -5.496048 & 3.194854 \\ \mathrm{H} & 0.493393 & -6.188634 & 4.027029 \\ \mathrm{C} & 0.391694 & -4.129674 & 3.438062 \\ \mathrm{H} & 0.365078 & -3.766995 & 4.458313 \\ \mathrm{C} & 0.346823 & -3.215900 & 2.390669 \\ \mathrm{H} & 0.276711 & -2.152879 & 2.592444 \\ \mathrm{C} & 0.379769 & -3.698499 & 1.097151 \\ \mathrm{C} & 2.456538 & 1.764288 & -0.143166 \\ \mathrm{C} & 3.321379 & 2.477364 & -1.170106 \\ \mathrm{H} & 2.541690 & -2.535384 \\ & & \end{array}$




$\begin{array}{cccc}\mathrm{H} & 5.819332 & 4.440201 & -3.324657 \\ \mathrm{C} & 5.313652 & 3.826769 & -1.336100 \\ \mathrm{H} & 6.160374 & 4.326971 & -0.881929 \\ \mathrm{C} & 4.401831 & 3.119307 & -0.561504 \\ \mathrm{C} & 4.317833 & 2.898963 & 0.881987 \\ \mathrm{C} & 5.126538 & 3.336902 & 1.921016 \\ \mathrm{H} & 6.007040 & 3.936516 & 1.724457 \\ \mathrm{C} & 4.785694 & 2.994952 & 3.222422 \\ \mathrm{H} & 5.402874 & 3.335537 & 4.044840 \\ \mathrm{C} & 3.657042 & 2.225362 & 3.482215 \\ \mathrm{H} & 3.400471 & 1.967071 & 4.502483 \\ \mathrm{C} & 2.844902 & 1.779765 & 2.445831 \\ \mathrm{H} & 1.960571 & 1.185840 & 2.650149 \\ \mathrm{C} & 3.186526 & 2.121641 & 1.153178 \\ \mathrm{C} & -2.649784 & 1.297214 & -0.043260 \\ \mathrm{C} & -3.670968 & 1.787562 & -1.059272 \\ \mathrm{C} & -3.521320 & 1.897973 & -2.427463 \\ \mathrm{H} & -2.570161 & 1.679481 & -2.899224 \\ \mathrm{C} & -4.614818 & 2.288874 & -3.189717 \\ \mathrm{H} & -4.516251 & 2.386637 & -4.263946 \\ \mathrm{C} & -5.838722 & 2.552996 & -2.582834 \\ \mathrm{H} & -6.684288 & 2.847238 & -3.192537 \\ \mathrm{C} & -5.985612 & 2.452386 & -1.206547 \\ \mathrm{H} & -6.940087 & 2.668618 & -0.741801 \\ \mathrm{C} & -4.890744 & 2.071835 & -0.441756 \\ \mathrm{C} & -4.738644 & 1.877128 & 0.998672 \\ \mathrm{C} & -5.651289 & 2.005640 & 2.034850 \\ \mathrm{H} & -6.678031 & 2.291545 & 1.839030 \\ \mathrm{C} & -5.222274 & 1.767642 & 3.333653 \\ \mathrm{H} & -5.921188 & 1.862271 & 4.155541 \\ \mathrm{C} & -3.902816 & 1.416018 & 3.592402 \\ \mathrm{H} & -3.583590 & 1.242710 & 4.612780 \\ \mathrm{C} & -2.985886 & 1.269206 & 2.556954 \\ \mathrm{H} & -1.963155 & 0.967321 & 2.756822 \\ \mathrm{C} & -3.420914 & 1.487735 & 1.264820 \\ \mathrm{O} & 0.083278 & -0.014650 & 2.215832 \\ \mathrm{P} & 0.060947 & 0.017827 & 0.727453 \\ & & & \end{array}$

\section{$\mathrm{H}_{3} \mathrm{PO}_{4}$ (PBE0/def2-QZVP)}

8 Coordinates from ORCA-job $\mathrm{H}_{3} \mathrm{PO}_{4}$

$\begin{array}{llll}\mathrm{O} & 1.005836 & -0.545188 & -1.035250 \\ \mathrm{P} & 0.064838 & 0.014432 & -0.0758315 \\ \mathrm{O} & 0.713103 & 0.627765 & 1.245093 \\ \mathrm{H} & 1.551189 & 0.202995 & 1.446658 \\ \mathrm{O} & -1.019729 & -1.014363 & 0.446508 \\ \mathrm{H} & -1.530716 & -0.691758 & 1.1934451 \\ \mathrm{O} & -0.810838 & 1.233811 & -0.586510 \\ \mathrm{H} & -0.455896 & 1.586902 & -1.406182\end{array}$




\section{$\mathrm{Ph}_{3} \mathrm{PO}$ (PBE0/def2-QZVP)}

35 Coordinates from ORCA-job $\mathrm{Ph}_{3} \mathrm{PO}$

$\begin{array}{lrrr}\mathrm{P} & 0.77689 & 0.27409 & 1.00896 \\ \mathrm{O} & 0.81055 & 0.24730 & 2.48810 \\ \mathrm{C} & 1.69396 & 1.65518 & 0.27769 \\ \mathrm{C} & 1.45013 & -1.21274 & 0.22772 \\ \mathrm{C} & -0.87696 & 0.46473 & 0.29851 \\ \mathrm{C} & 1.37146 & 2.16975 & -0.97609 \\ \mathrm{C} & 2.10913 & 3.21079 & -1.51609 \\ \mathrm{C} & 3.17384 & 3.74741 & -0.80556 \\ \mathrm{C} & 3.49451 & 3.24487 & 0.44770 \\ \mathrm{C} & 2.75989 & 2.19979 & 0.98890 \\ \mathrm{C} & 2.18921 & -1.18339 & -0.95154 \\ \mathrm{C} & 2.62304 & -2.36522 & -1.53246 \\ \mathrm{C} & 2.32608 & -3.58141 & -0.93583 \\ \mathrm{C} & 1.60425 & -3.61555 & 0.24975 \\ \mathrm{C} & 1.17004 & -2.43649 & 0.83267 \\ \mathrm{C} & -1.31602 & -0.24824 & -0.81333 \\ \mathrm{C} & -2.55626 & 0.02767 & -1.37281 \\ \mathrm{C} & -3.35738 & 1.01841 & -0.82633 \\ \mathrm{C} & -2.93368 & 1.71617 & 0.29785 \\ \mathrm{C} & -1.69806 & 1.44201 & 0.85808 \\ \mathrm{H} & 0.53195 & 1.76069 & -1.52558 \\ \mathrm{H} & 1.84597 & 3.60977 & -2.48810 \\ \mathrm{H} & 3.74821 & 4.56378 & -1.22627 \\ \mathrm{H} & 4.31755 & 3.67223 & 1.00720 \\ \mathrm{H} & 2.99383 & 1.80663 & 1.97108 \\ \mathrm{H} & 2.43099 & -0.23584 & -1.41671 \\ \mathrm{H} & 3.19562 & -2.33553 & -2.45121 \\ \mathrm{H} & 2.66544 & -4.50365 & -1.39209 \\ \mathrm{H} & 1.38051 & -4.56378 & 0.72328 \\ \mathrm{H} & 0.61985 & -2.45191 & 1.76585 \\ \mathrm{H} & -0.68755 & -1.01755 & -1.24546 \\ \mathrm{H} & -2.89238 & -0.52658 & -2.24073 \\ \mathrm{H} & -4.31755 & 1.24701 & -1.27299 \\ \mathrm{H} & -3.56664 & 2.47864 & 0.73455 \\ \mathrm{H} & -1.35979 & 1.98058 & 1.73548\end{array}$

\section{Radical anion $\mathrm{Ph}_{3} \mathrm{PO}^{\circ-}(\mathrm{PBE} /$ def2-TZVPP)}

Coordinates from ORCA-job pbe0_def2_RA
P 0.09948243078419
$-0.14650790960658$
1.01859486299680
O $\quad 0.22018079822970$
$-0.19661663379118$
2.50461156733376
C 1.00217553158969
$1.21610404147644 \quad 0.29617523273293$
C 0.70417076380734
$-1.62778913761781$
0.18238074554966
C -1.59636954761468
$0.05096003325290 \quad 0.45782506667496$
C 0.86079727744806
$\begin{array}{ll}1.58923738967331 & -1.05959869437728\end{array}$ 


$\begin{array}{cccc}\text { C } & 1.52555166412180 & 2.68683484527219 & -1.56855554126378 \\ \text { C } & 2.33469644053232 & 3.47639994291640 & -0.74765948439505 \\ \text { C } & 2.42974465076757 & 3.15212258907801 & 0.61042963473133 \\ \text { C } & 1.77519996075296 & 2.05126568358832 & 1.12544685124909 \\ \text { C } & 1.47422438424601 & -1.62631159399880 & -0.98252444017633 \\ \text { C } & 1.91601743924671 & -2.80901674070995 & -1.54771410956737 \\ \text { C } & 1.61240925974229 & -4.03340502476763 & -0.94336943484219 \\ \text { C } & 0.87462298958645 & -4.04448166707994 & 0.23179331332184 \\ \text { C } & 0.42183115099558 & -2.86070047629049 & 0.79519804549643 \\ \text { C } & -2.10788040208351 & -0.60104843112820 & -0.68186917868137 \\ \text { C } & -3.31953853071064 & -0.22842588686148 & -1.23279755227324 \\ \text { C } & -4.05632575879667 & 0.82562941996843 & -0.68933021841140 \\ \text { C } & -3.55040524551263 & 1.49135169741988 & 0.43412670972798 \\ \text { C } & -2.35037208304439 & 1.11594270615979 & 0.99568021777128 \\ \text { H } & 0.19224277661977 & 1.02566806236519 & -1.70062188194158 \\ \text { H } & 1.39223733551008 & 2.95250251252896 & -2.61278589763155 \\ \text { H } & 2.85646923187987 & 4.33703767639895 & -1.14908575491183 \\ \text { H } & 3.03417996729277 & 3.76762824544057 & 1.26873058777208 \\ \text { H } & 1.85570751745988 & 1.79481390411692 & 2.17553258801410 \\ \text { H } & 1.73693418056952 & -0.68345610445246 & -1.44553714831696 \\ \text { H } & 2.50331293243200 & -2.78191644529248 & -2.45860909812714 \\ \text { H } & 1.96436503209509 & -4.96066071025261 & -1.38165960061553 \\ \text { H } & 0.64814875111551 & -4.98765548121813 & 0.71875260841791 \\ \text { H } & -0.13811425031480 & -2.86899825703805 & 1.72249491451980 \\ \text { H } & -1.53876226669900 & -1.40879324910180 & -1.12826953957993 \\ \text { H } & -3.69648637456717 & -0.76122947196207 & -2.10013466937906 \\ \text { H } & -4.99190707373184 & 1.13642525701065 & -1.13869611320120 \\ \text { H } & -4.11182135401934 & 2.30863834065715 & 0.87524426237496 \\ \text { H } & -1.96769357973050 & 1.63730587384560 & 1.86579814900786\end{array}$




\section{References}

[1] H. Tsuji, T. Inoue, Y. Kaneta, S. Sase, A. Kawachi, K. Tamao, Organometallics 2006, 25, 6142-6148.

[2] D. F. Eaton, J. Photochem. Photobiol, B 1988, 2, 523-531.

[3] W. M. Haynes, D. R. Lide, T. J. Bruno, CRC Handbook of Chemistry and Physics: A readyreference book of chemical and physical data; CRC Press, Boca Raton (Fla.), London, New York, 2013.

[4] F. Neese, Diploma thesis, University of Konstanz (Konstanz, Germany), 1993.

[5] O. V. Dolomanov, L. J. Bourhis, R. J. Gildea, Howard, J. A. K, H. Puschmann, J. Appl. Crystallogr. 2009, 42, 339-341.

[6] G. M. Sheldrick, Acta Crystallogr. A Found. Crystallogr. 2008, 64, 112-122.

[7] D. Hellwinkel, W. Krapp, Chem. Ber. 1978, 111, 13-41.

[8] C. Poriel, Y. Ferrand, S. Juillard, P. Le Maux, G. Simonneaux, Tetrahedron 2004, 60, 145158.

[9] D. Geuenich, K. Hess, F. Köhler, R. Herges, Chem. Rev. 2005, 105, 3758-3772.

[10] C. Chuit, R. J. P. Corriu, P. Monforte, C. Reyé, J.-P. Declercq, A. Dubourg, Angew. Chem. Int. Ed. 1993, 32, 1430-1432.

[11] L.-S. Cui, S.-C. Dong, Y. Liu, M.-F. Xu, Q. Li, Z.-Q. Jiang, L. S. Liao, Org. Electron. 2013, 14, 1924-1930.

[12] R. R. Shifrina, I. P. Romm, E. N. Gur'yanova, N. A. Rozanel'skaya., J. Appl. Spectrosc. 1981, 111-115.

[13] a) R. A. Zingaro, R. M. Hedges, J. Phys. Chem. 1961, 65, 1132-1138; b) J. M. Casper, E. E. Remsen, Spectrochim. Acta, Part A 1978, 34, 1-4.

[14] F. A. Cotton, R. D. Barnes, E. Bannister, J. Chem. Soc. 1960, 2199-2203.

[15] J. Pommerehne, H. Vestweber, W. Guss, R. F. Mahrt, H. Bässler, M. Porsch, J. Daub, Adv. Mater. 1995, 7, 551-554.

[16] a) J. Rault-Berthelot, M. M. Granger, L. Mattiello, Synth. Met. 1998, 97, 211-215; b) D. Horhant, J.-J. Liang, M. Virboul, C. Poriel, G. Alcaraz, J. Rault-Berthelot, Org. Lett. 2006, 8, 257-260.

[17] A. G. Evans, J. C. Evans, D. Sheppard, J. Chem. Soc, Perkin Trans. 2 1976, 1166-1169.

[18] Il'yasov, A. V, Kargin, Yu. M, Levin, Ya. A, Morozova, I. D, Mel'nikov, B. V, Vafina, A. A, Sotnikova, N. N, Galeev, V. S, Izv. Akad. Nauk SSSR, Ser. Khim. 1971, 770-776.

[19] A. H. Cowley, M. H. Hnoosh, J. Am. Chem. Soc. 1966, 88, 2595-2597.

[20] A. D. Becke, J. Chem. Phys. 1993, 98, 5648-5652.

[21] a) C. Lee, W. Yang, R. G. Parr, Phys. Rev. B 1988, 37, 785-789; b) B. Miehlich, A. Savin, H. Stoll, H. Preuss, Chem. Phys. Lett. 1989, 157, 200-206.

[22] J. P. Perdew, K. Burke, M. Ernzerhof, Phys. Rev. Lett. 1996, 77, 3865-3868.

[23] J. P. Perdew, K. A. Jackson, M. R. Pederson, D. J. Singh, C. Fiolhais, Phys. Rev. B 1992, 46, 6671-6687.

[24] a) R. Ditchfield, W. J. Hehre, J. A. Pople, J. Chem. Phys. 1971, 54, 724-728; b) W. J.

Hehre, R. Ditchfield, J. A. Pople, J. Chem. Phys. 1972, 56, 2257-2261.

[25] F. Weigend, R. Ahlrichs, Phys. Chem. Chem. Phys. 2005, 7, 3297-3305.

[26] R. Peverati, D. G. Truhlar, Phys. Chem. Chem. Phys. 2012, 14, 16187-16191.

[27] M. J. Frisch, G. W. Trucks, H. B. Schlegel, G. E. Scuseria, M. A. Robb, J. R. Cheeseman, G. Scalmani, V. Barone, B. Mennucci, G. A. Petersson, H. Nakatsuji, M. Caricato, X. Li, H. P. Hratchian, A. F. Izmaylov, J. Bloino, G. Zheng, J. L. Sonnenberg, M. Hada, M. Ehara, K. Toyota, R. Fukuda, J. Hasegawa, M. Ishida, T. Nakajima, Y. Honda, O. Kitao, 
H. Nakai, T. Vreven, J. A. Montgomery, Jr, J. E. Peralta, F. Ogliaro, M. Bearpark, J. J. Heyd, E. Brothers, K. N. Kudin, V. N. Staroverov, R. Kobayashi, J. Normand, K.

Raghavachari, A. Rendell, J. C. Burant, S. S. Iyengar, J. Tomasi, M. Cossi, N. Rega, J. M. Millam, M. Klene, J. E. Knox, J. B. Cross, V. Bakken, C. Adamo, J. Jaramillo, R. Gomperts, R. E. Stratmann, O. Yazyev, A. J. Austin, R. Cammi, C. Pomelli, J. W. Ochterski, R. L. Martin, K. Morokuma, V. G. Zakrzewski, G. A. Voth, P. Salvador, J. J. Dannenberg, S. Dapprich, A. D. Daniels, Ö. Farkas, J. B. Foresman, J. V. Ortiz, J. Cioslowski, and D. J. Fox, Gaussian, Inc, Wallingford CT 2009.

[28] J. Perdew, Phys. Rev. B 1986, 33, 8822-8824.

[29] J. Tao, J. Perdew, V. Staroverov, G. Scuseria, Phys. Rev. Lett. 2003, 91, 146401.

[30] J. P. Perdew, K. Burke, M. Ernzerhof, Phys. Rev. Lett. 1997, 78, 1396.

[31] C. Adamo, V. Barone, J. Chem. Phys. 1999, 110, 6158-6170.

[32] F. Neese, WIREs Comput. Mol. Sci. 2012, 2, 73-78.

[33] S. Grimme, J. Antony, S. Ehrlich, H. Krieg, J. Chem. Phys. 2010, 132, 154104.

[34] S. Grimme, S. Ehrlich, L. Goerigk, J. Comput. Chem. 2011, 32, 1456-1465.

[35] M. C. Zerner, G. H. Loew, R. F. Kirchner, U. T. Mueller-Westerhoff, J. Am. Chem. Soc. 1980, 102, 589-599.

[36] a) F. London, J. Phys. Radium. 1937, 8, 397-409; b) K. Wolinski, J. F. Hinton, P. Pulay, J. Am. Chem. Soc. 1990, 112, 8251-8260; c) J. R. Cheeseman, G. W. Trucks, T. A. Keith, M. J. Frisch, J. Chem. Phys. 1996, 104, 5497-5509; d) R. Ditchfield, Mol. Phys. 1974, 27 , 789-807; e) R. McWeeny, Phys. Rev. 1962, 126, 1028-1034.

[37] W. Kutzelnigg, U. Fleischer, M. Schindler in Deuterium and shift calculation, NMR Basic Principles and Progress; (Eds. P. Diehl, E. Fluck, H. Günther, R. Kosfeld, J. Seelig, U. Fleischer, W. Kutzelnigg, H.-H. Limbach, G. J. Martin, M. L. Martin, M. Schindler), Springer, Berlin, Heidelberg, 1991, pp. 165-262.

[38] R. Herges, D. Geuenich, J. Phys. Chem. A 2001, 105, 3214-3220.

[39] I. Mayer, Chem. Phys. Lett. 1983, 97, 270-274.

[40] R. Naaman, Z. Vager, The structure of small molecules and ions; Springer, Boston, MA, 1988

[41] Bader, R. F. W, Atoms in molecules: A quantum theory; Clarendon Press, Oxford, New York, 1990.

[42] A. D. Becke, K. E. Edgecombe, J. Chem. Phys. 1990, 92, 5397-5403.

[43] T. Lu, F. Chen, J. Comput. Chem. 2012, 33, 580-592.

[44] A. D. Laurent, D. Jacquemin, Int. J. Quantum Chem. 2013, 113, 2019-2039.

[45] J. Fabian, Dyes Pigm. 2010, 84, 36-53. 